\title{
“Talking” Tiles from Vanished Ilkhanid Palaces (Late Thirteenth to Early Fourteenth Centuries): Frieze Luster Tiles with Verses from the Shah-nama
}

Yves Porter ${ }^{1}$ | ORCID: 0000-0003-1038-141X

Professor, Aix Marseille Université/CnRs Laboratoire d'Archéologie Méditerranéennes

Médiévale et Moderne/Institut Universitaire de France, Marseille, France

yves.porter@orange.fr

\begin{abstract}
Luster tiles in Ilkhanid palace decoration are repeatedly linked with the site of Takht-i Sulaiman (Iran). However, the collection and analysis of ninety-two frieze luster tiles (or fragments) characterized by a similar scheme indicates the existence of other palatial locations. Sorting the tiles results in at least eight different friezes. Consequently, possible locations of other Ilkhanid palaces are investigated. Textual contents mainly originate from Firdausi's Shah-nama. However, the excerpts found on tiles are seldom narrative but allude to the enjoyment of nature, drinking, and beauty. The suitability of these poetic quotes for Ilkhanid palace decoration is thus further analyzed.
\end{abstract}

\section{Keywords}

luster tiles - Ilkhanid palaces - Takht-i Sulaiman - Shah-nama - ceramics - monumental epigraphy

The words of the prophets

Are written on the subway walls

And tenement halls

PAUL SIMON, The Sound of Silence

Recent work, such as the remarkable monography by Viola Allegranzi on the poetic inscriptions in the Ghaznavid palace of Ghazni, emphasizes the importance of epigraphy in palatial architecture (Allegranzi, 2019). At the other end of the Islamic world, this aspect has attracted scholars working on Nasrid architecture, particularly the emblematic Alhambra palace, with walls decorated with verses written by celebrated poets (Puerta Vilchez, 2010). However, while both these examples show the unique 
FIGURE 1

Tile fragment (Museum für Islamische Kunst Nr. I. 4/67.35.2) repositioned in a complete tile (Cat. 1.13)

(C) ALL DRAWINGS BY THE AUTHOR

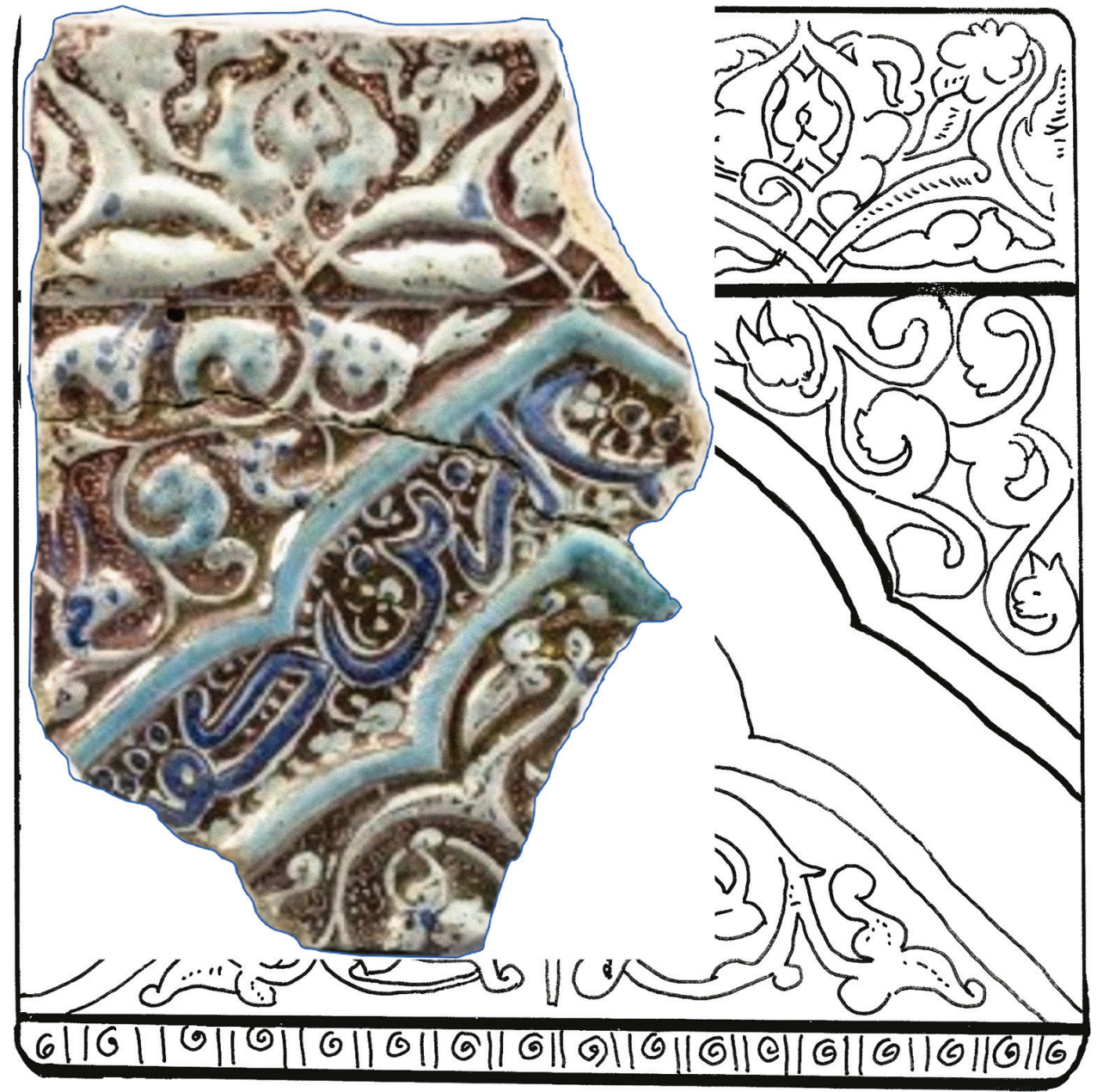

inscription of poems composed for their specific places inside these palaces, presenting the suitability of their contents and meaning for the walls they adorn, the cases addressed in this essay concern only quotations from a preexisting literary masterpiece, Firdausi's (1966) Shah-nama (Mélikian-Chirvani, 1988, 1996). Moreover, contrary to the Ghaznavid and Nasrid purposely composed poems, the tiles studied here illustrate the use of multipliable (stereotyped?) inscriptions; their meaning, and subsequently their suitability for their site, might then be less directly appreciated.

Although Firdausi's verses appear on various tiles (such as square or star-shaped) produced during the Ilkhanid period (1258-1335), only a single type of square tile, decorated with luster and each displaying a hemistich from the Shah-nama, is considered hereafter; this group of tiles is often associated with the Ilkhanid palace of Takht-i Sulaiman, in Iranian Azerbaijan, although only some fragments were found in situ (Fig. 1). ${ }^{2}$ In addition to this site, scattered tiles, sometimes in fragments, have been found in other locations, the most unexpected group being inserted under the cupola of an Armenian church. ${ }^{3}$

Several authors have explored this group of tiles in a series of publications. ${ }^{4}$ Since then, new tiles have been added to the group, their number now sufficient to form an impression of their general textual contents. Unfortunately, since most of the tiles preserved in public and private collections worldwide originated from the art market, their provenance is undocumented. Persian luster tiles entered European collections around the 1870s, if not before (Masuya, 2000). Tomoko Masuya has noted that two 


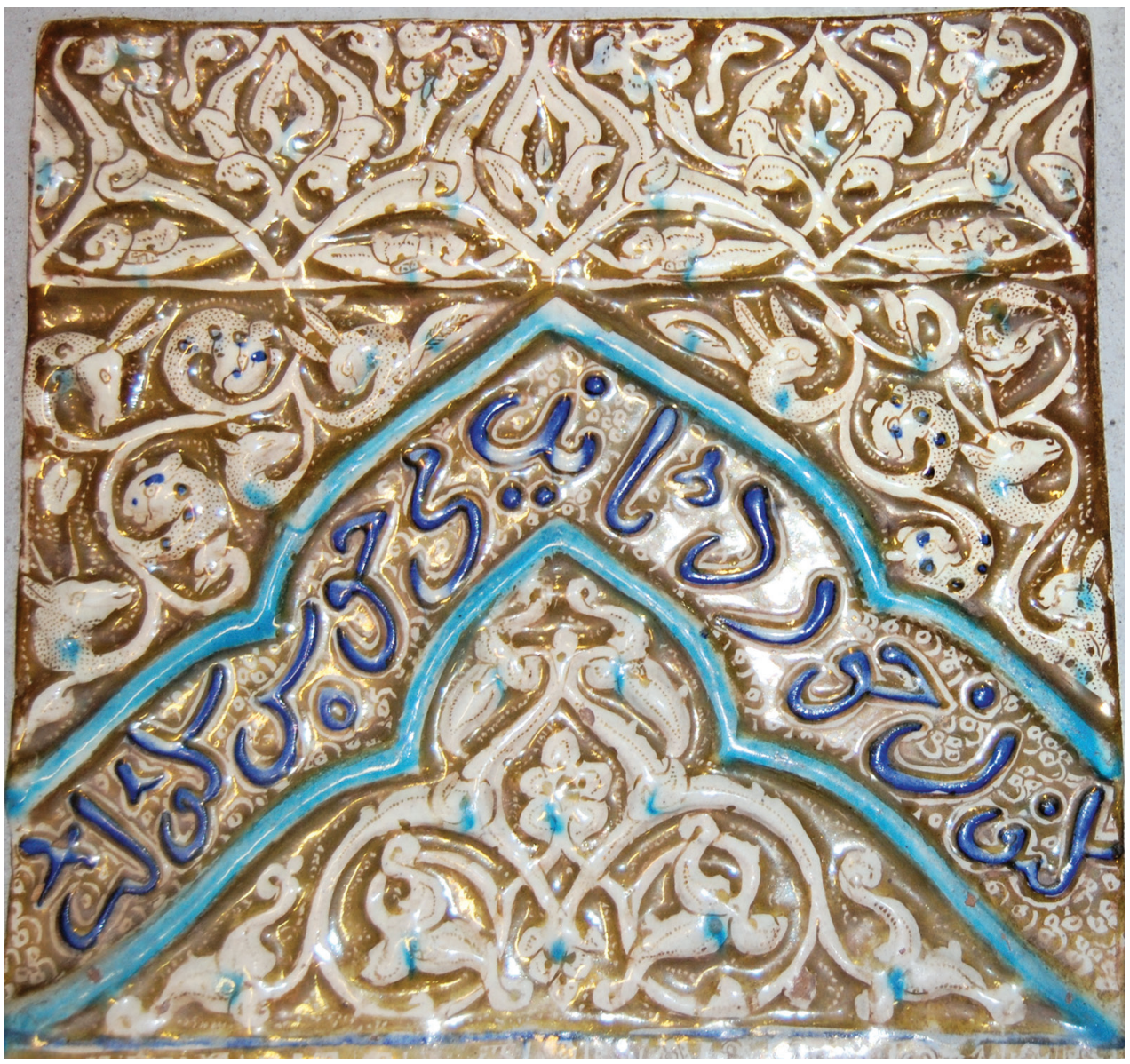

tiles in the British Museum were bequeathed by John Henderson after his death in 1878 (Figs. 2-3), ${ }^{5}$ while the pair now at San Francisco's Asian Art Museum originated from Octave Homberg's collection, documented in a 1904 photograph of his living room (Masuya, 1997: 492). ${ }^{6}$

Despite the repeated attribution of these tiles to the single site of Takht-i Sulaiman, the study of the typology and characteristics of this ensemble reveals that all the items could not have a single origin, as is demonstrated hereafter. Moreover, since the origin of a vast majority of these tiles is unknown, the possibility that some might have been reused in premodern times complicates the task of determining their original abode. Thus, several groups are proposed hereafter, based on size, typological, and decorative data. Each of these series could mark the existence of different palatial locations.

A first step involves inventorying and sorting the remaining tiles according to their exact quotations from the Shah-nama, together with their dimensions and decorative details. Ninety-two tiles (including eleven fragments) have been catalogued; they represent at least eight different series. Cataloguing also determines the textual contents of each series and thus highlights the existence of similar tiles with the same text (Table 1).

The production of Iranian luster tiles is admittedly associated with the unique manufacturing city of Kashan, in central Iran..$^{7}$ All the tiles are generally described as made from molded frit paste, each verse being individually hand-formed with a paste coil; the whole is covered with a white tin-based glaze, highlighted with cobalt and copper oxides. After firing, the tiles are painted with luster before undergoing a final firing in a reducing atmosphere. These materials and processes represent the basic or recurrent modus operandi; however, more detailed analyses of the body's petrofabrics or the exact
FIGURE 2

Tile from Frieze I; text: Konun khword bāyad mey-e khosh gavār / Now [we] must drink this exquisite wine. (Cat. 1.28) British Museum, no. 1878,1230.573.1 (C) THE TRUSTEES OF THE BRITISH MUSEUM 
FIGURE 3

Tile from Frieze I; text: Shavad āsemān hamcho posht-e palang I The sky will become like the skin of the panther. (Cat. 1.39) British Museum, no. 1878,1230.573.2 (C) THE TRUSTEES OF THE BRITISH MUSEUM
TABLE 1

Number of tiles per series (C) YVES PORTER
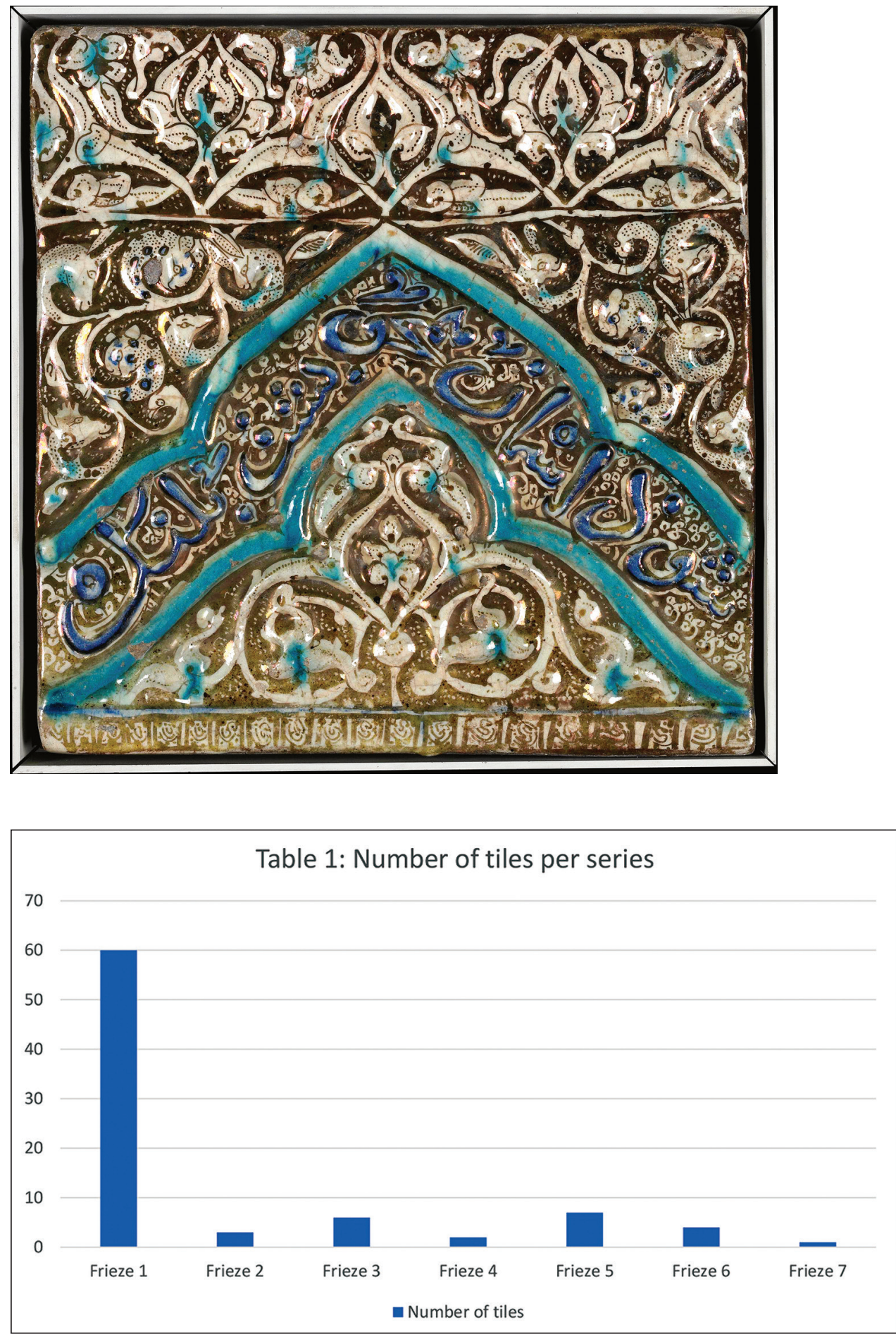

composition of the oxides used for the glazing could show some variants, confirming differences in the origin of materials or changes in the processes (Porter, 2018: 433-6). Thus, although detailed data on these topics are missing, physicochemical analyses could not be conducted during the present research. ${ }^{8}$

The textual contents of the tiles, together with their decor, indicate their use in palace decoration since no example on religious buildings is known. Accordingly, some hypotheses regarding their initial homes should be proposed. However, in the absence of field archaeological surveys, these hypotheses cannot transcend mere propositions. These imply considering the ensemble of Ilkhanid palaces and seasonal residences, 
which are surveyed mainly through literary sources, thus allowing definition of a context for displaying these tiles. Based on the example of Takht-i Sulaiman, it is generally assumed that this type of tile decoration originally belonged to royal palaces; however, the presence of such decor in nonroyal secular buildings, belonging to grandees of the empire, cannot be fully discarded.

Finally, the way these revetments were originally displayed on the palaces' walls is considered. Accordingly, their layout, together with their literary content, is further examined. The sorting of textual quotes on the studied tiles leads to several issues; these first concern the choice of the excerpts from Firdausi's Shah-nama. However, one of the series, showing a particular adaptation of the trilobed scheme in a larger template, displays a poem composed by another author, Anvari (d. c. 1189-91). Revealingly, this qasida (or panegyric) is an ode to a vanished palace.

Previous studies on these tiles each concentrate on a specific theme or approach: Watson includes them in his general survey of Persian Lustre Ware, while MélikianChirvani focusses on the symbolic importance of the Shah-nama quotations. Masuya incorporates them in her study of Takht-i Sulaiman. The present contribution aims, through a bottom-up approach, to reconstruct the context of lost buildings and their decors, taking the tiles as a starting and central object of study.

Archaeological sites of royal palaces yield objects linked to a particular environment and reflect a specific and immediate research ground. In a second stage, excavated artifacts can be linked to other now dispersed objects whose traceability is seldom complete.

Simultaneously, primary sources often provide information and contexts relating to some sites. However, as indirect witnesses, they might already be biased and subject to interpretation; a critical reading of both objects and sources is thus required. ${ }^{9}$

Optimally, the collection of tangible data (represented here by the different series of tiles) should lead to relevant combinations intended to elaborate a system of understanding without losing view of the reality on the ground (i.e., different possible palace locations). As far as possible, the goal should be to avoid interpretations arising from exterior schemes projected on reality to mold them into a preconceived idea (i.e., the symbolic role of Takht-i Sulaiman).

Frieze Tiles with Verses from the Shah-nama

The Shah-nama, composed by Firdausi by the end of the tenth century, contains about $5^{\circ}$,ooo distiches and is thus among the longest poems in world literature. In his study on the friezes with verses from the Shah-nama, Mélikian-Chirvani numbers at least twenty-one different series (Mélikian-Chirvani, 1996). ${ }^{10}$ Besides different series of "linear tiles" either decorated with luster or turquoise glaze, ninety-two localized tiles (or fragments) now exist, inscribed with verses from the Shah-nama inside a trilobed arch, known to this day (see Catalogue of tiles). Even if one considers that the inventoried tiles constitute only a small portion of what existed in the late thirteenth to early fourteenth centuries, it appears obvious that the friezes did not quote the totality of the epic but only some "morceaux choisis."

Most of these friezes are formed from large, almost square tiles (29-30 $\mathrm{cm}$ each side), although a slightly smaller template also exists (approx. $26 \mathrm{~cm}$ each side). A careful examination shows that the upper and lower borders, together with the spandrel motifs of these tiles, display different patterns, each variation probably implying different series, hence different locations. Moreover, even in the same model series (hereafter, Frieze I), the same hemistich appears at least on four pairs of tiles, indicating that two extremely similar series also existed. 
None of the square frieze tiles are dated; the comparison with Takht-i Sulaiman's dated eight-pointed stars (670-4/1271-6) allowed Masuya to define four phases in their making (Masuya, 1997: 369-70). However, assuming that the different series of square tiles might also belong to other locations, they might have a more expanded chronology.

\subsection{Luster Tiles with Trilobed Arch: Takht-i Sulaiman's Frieze}

The tiles of Takht-i Sulaiman's frieze are molded and painted in luster on a white background, with dashes of cobalt and turquoise, and have an almost square shape (approx. $30 \mathrm{~cm}$ each side); the upper band displays a series of double split leaves and palmettes forming a two-level network.

The main field is occupied by a trilobed arch formed from a double line, painted in turquoise; between these lines is the Persian text, written in slight relief and painted with cobalt, in naskhi script. When comparing two tiles with the same hemistich (see Figs. 2-3 and 5-6), one can notice that the written quote is not molded but hand fashioned. The spandrels are decorated with scrolls ending with animal heads (often qualified as a waq-waq motif,"11 although according to Mélikian-Chirvani (1984: 305-7; 1991: 100-1), the pattern could be inspired by the "Talking Tree" story in the Book of Alexander). Under the trilobe stands a symmetrical composition of split leaves. The lower border is a narrow, molded cornice decorated with a double stroke pattern alternating with an irregular coiled motif accompanied by three dots and several incurved thin strokes. This border pattern is reminiscent of a written abbreviation, such as the "läm-alif" or the Alafia. ${ }^{2}$

As already noted, only some fragments of incomplete tiles are reported to have been found at Takht-i Sulaiman. The larger fragment, first read by Mélikian-Chirvani, represents less than half a complete tile (Mélikian-Chirvani, 1984: 276; Fig. 1); moreover, the lower narrow frieze (notably differentiating Friezes I and II) is missing. The other excavated fragments are much smaller and contain no readable text.

The extreme paucity of these finds can be explained either by previous depredations or because these tiles were already reused during the early fourteenth century, not only on other secular buildings but also in some quite far-off locations. As mentioned above, a curious example of this type of long-distance reuse is found in the Church of Eghvard, which displays several tiles of the "Takht-i Sulaiman" series, inserted at the base of its cupola (Donabédian and Porter, 2017; Gyuzalyan, 1984; Mélikian-Chirvani, 1996: 10; Fig. 4).

Combining Mélikian-Chirvani's and Masuya's inventories with previously unnoticed tiles led to a preliminary list of the so-called Takht-e Sulaiman (or "First") frieze comprising approximately sixty-three tiles (complete or fragments; see Catalogue of tiles).$^{13}$

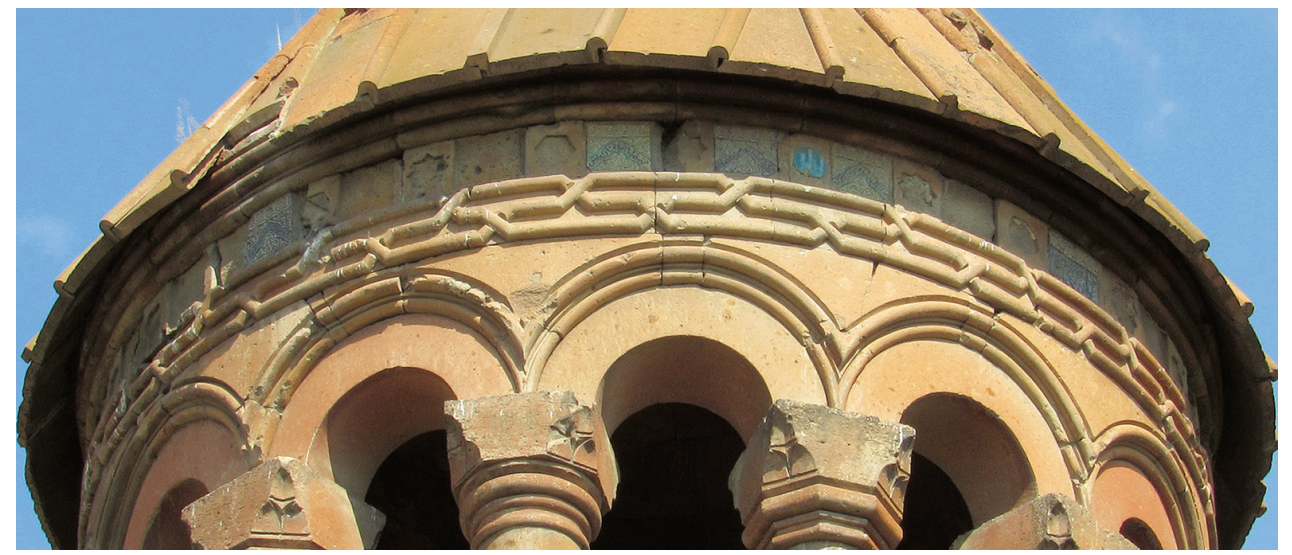

FIGURE 4

Frieze of luster tiles at the base of Eghvard Church, view from the south-east

(C) PHOTO P. DONABÉDIAN 

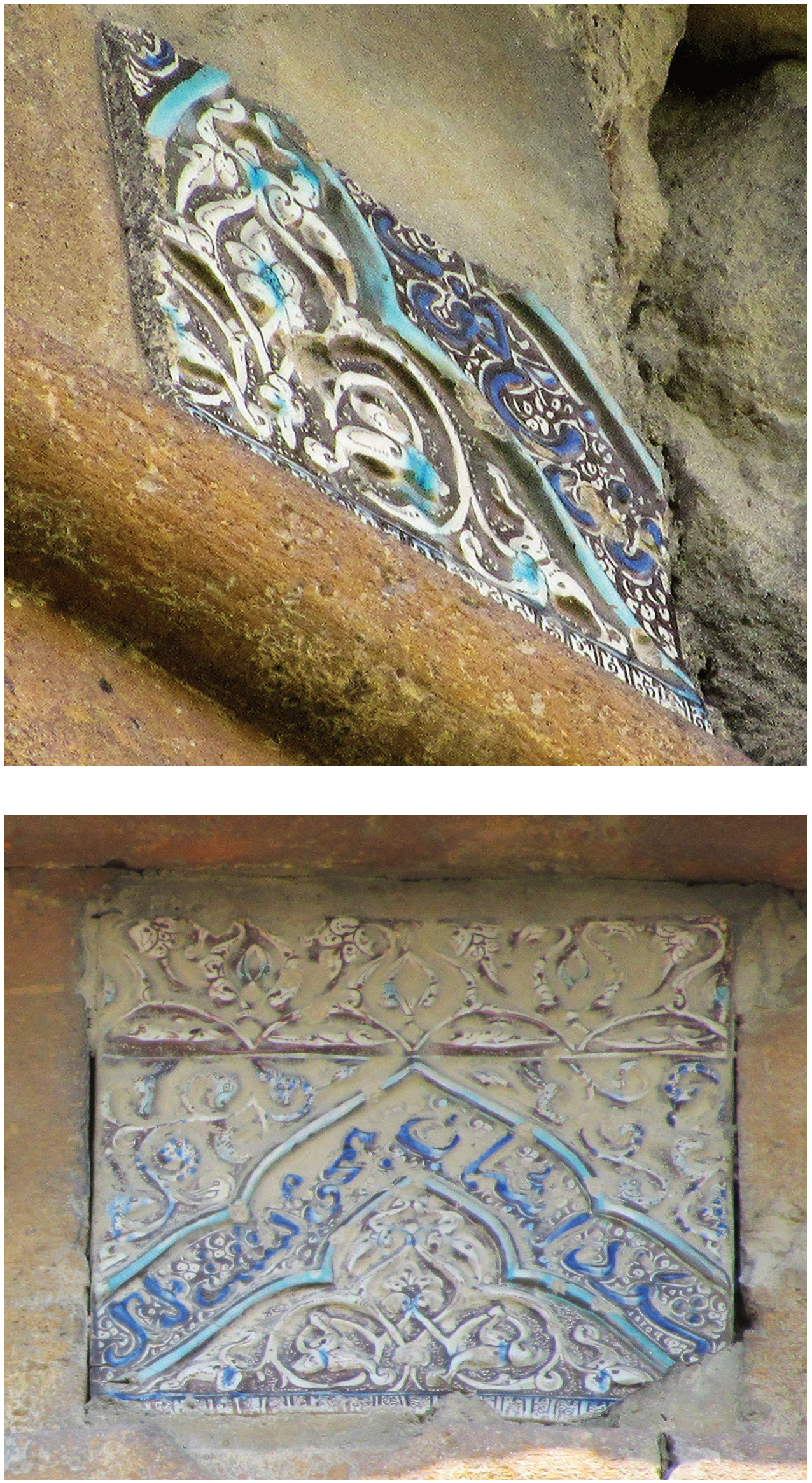

FIGURE 5

Eghvard, Tile 13; text: Konun khword bāyad mey-e khosh gavār / Now [we] must drink this exquisite wine. (Cat. 1.29) (C) PHOTO P. DONABÉDIAN

GURE 6

Eghvard, Tile 51; text: Shavad äsemān hamcho posht-e palang / The sky will become like the skin of the panther. (Cat. 1.40)

(C) PHOTO P. DONABÉDIAN 
However, as already mentioned, some tiles display the same decor and hemistich, indicating that at least two "twin" series exist. The Eghvard Church displays several types of luster tiles encrusted in its stone facing, forming a continuous frieze (Gyuzalyan, 1984; Zhamkotchyan and K'alantaryan, 1971). Among the remaining tiles, nine follow the characteristics of our Frieze I, two of them displaying the same decor and hemistich as two other tiles in the British Museum (Figs. $2-3$ and $5^{-6}$ ). ${ }^{14}$ Thus, two almost identical friezes exist, probably illustrating the decor of two distinct palaces.

Frieze I is represented by the largest number of surviving tiles, although this could also be explained by the existence of two almost identical series.

The exact origin of the tiles reused in Eghvard remains impossible to determine. It could be assumed that they did not originate from Takht-i Sulaiman, first because it appears strange to have two identical friezes in the same location and also because the distance between both sites is critical ( $472 \mathrm{~km}$, as the crow flies; Fig. 18). A nearer building would, then, appear more plausible. An Ilkhanid palace could have existed in the vicinity of Dvin, Garni, or even Ani, where fragments of luster tiles have been recovered. ${ }^{15}$

\subsection{The Other Tiles with Trilobed Arches}

As Mélikian-Chirvani confirmed previously, several other series of tiles with trilobed arches and verses from the Shah-nama are known. In parallel with the two similar series of Takht-i Sulaiman and Eghvard, at least three of them have similar sizes (approx. $29-30 \times 30 \mathrm{~cm}$ each side), the variations concerning mainly the decorative motifs of the upper frieze, spandrels, and lower frieze.

Following Mélikian-Chirvani's (1996: 9-10) analysis, Frieze II only differentiates from Frieze I in its lower border, here composed of a row of "pearls" rather than the "lām-alif" motif of Frieze I. To my knowledge, only three tiles from this frieze are identified (Cat. 2.1-2.3; Fig. 7).

What could be tentatively named Frieze III offers a different decor: the upper border shows a large epigraphic band in Kufic script (abbreviation of al-mulk?). ${ }^{16}$ Moreover, the spandrels display a pair of flying birds. The precise ornithological species might not be relevant here since these birds probably represent a hybrid of the recently arrived

FIGURE 7

Tile from Frieze II; text: Ke man shārestān-am 'aliyam darast / I am [like] palace and garden, 'Ali is my gate. (Cat. 2.1) MNC Sèvres 18289a (C) PHOTO YVES PORTER

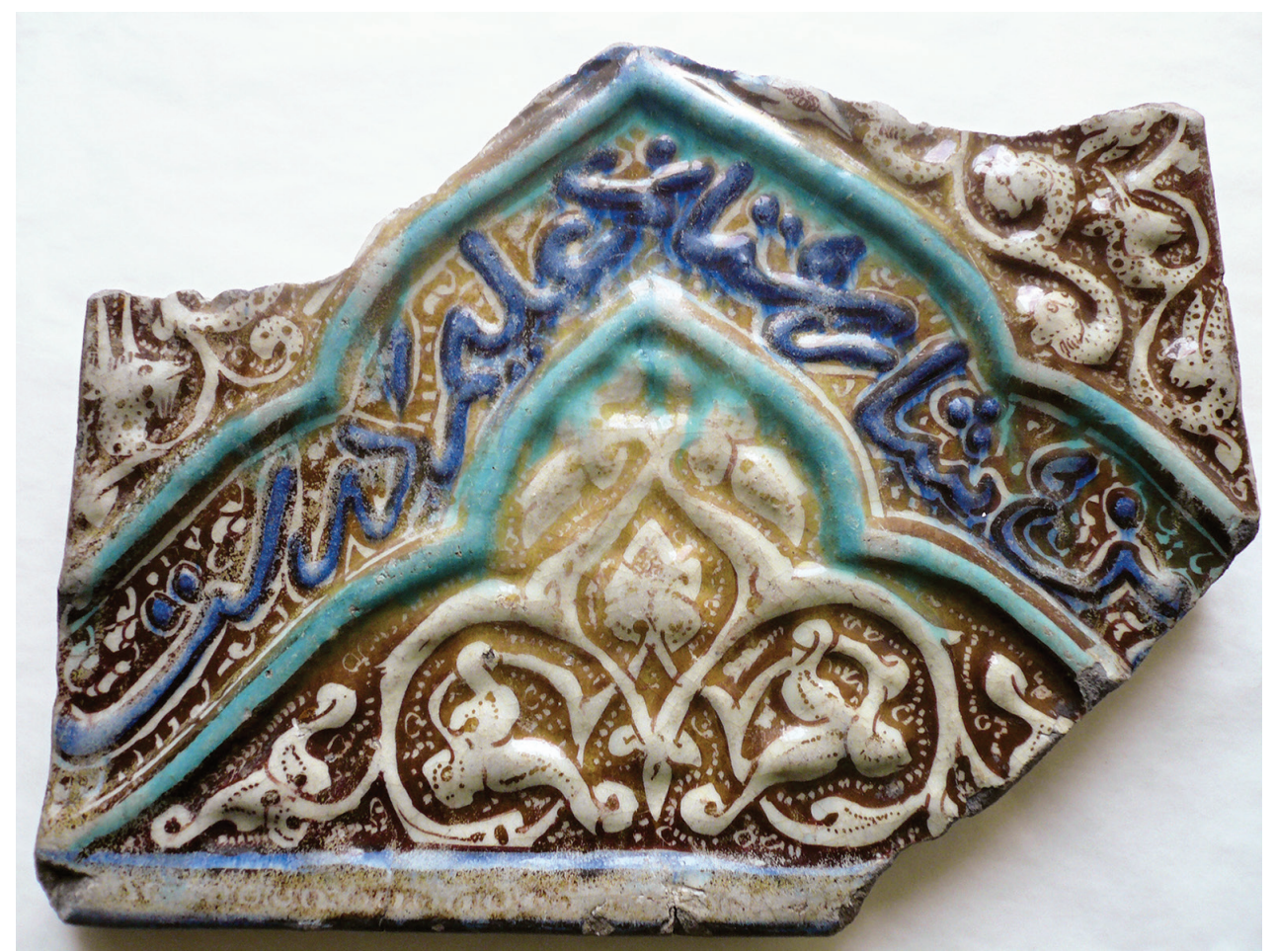


phoenix and other types of birds such as peacocks, cranes, or geese; at any rate, the flying bird motif easily adapts to the "formal opportunity" represented by the almost triangular surface of a spandrel. ${ }^{17}$ Three complete tiles exist (all originating from London sales), and three other fragmentary items (Figs. 8 and 9) were recorded for this frieze (Cat. 3.1-3.6).
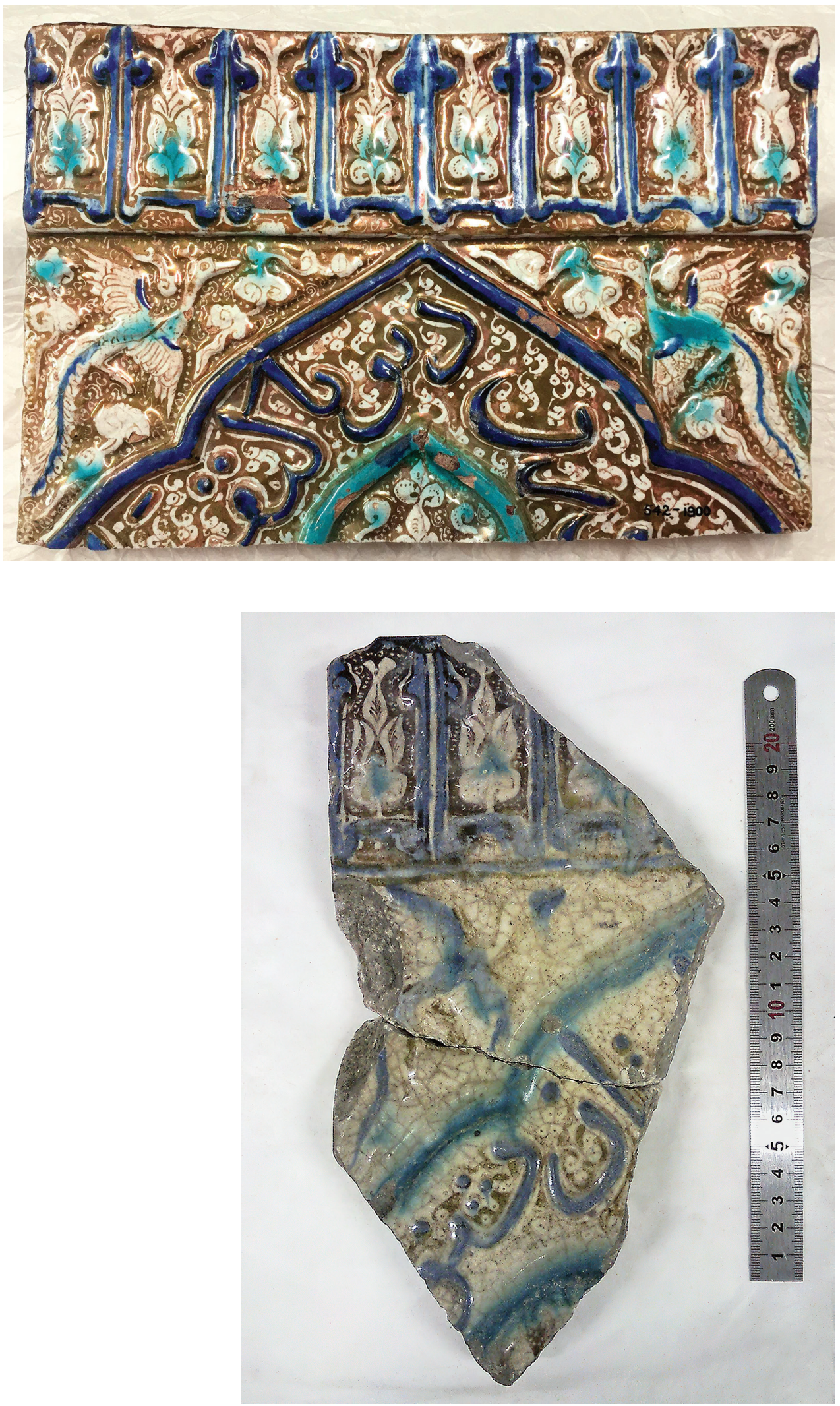

\section{FIGURE 8}

Tile from Frieze III (Cat. 3.4), Victoria and Albert Museum, no. 542-190o

(C) VICTORIA AND ALBERT MUSEUM, LONDON
FIGURE 9

Fragment from tile of Frieze III (Cat. 3.6), MNC Sèvres (sn) (C) PHOTO YVES PORTER 
FIGURE 10

Tile from Frieze IV; text: [Do abru kamān va] do narges dozham /

Two eyebrows like a bow and two cruel narcissus. (Cat. 4.2) Victoria and Albert Museum, no. 544-19oo (C) VICTORIA AND ALBERT MUSEUM, LONDON

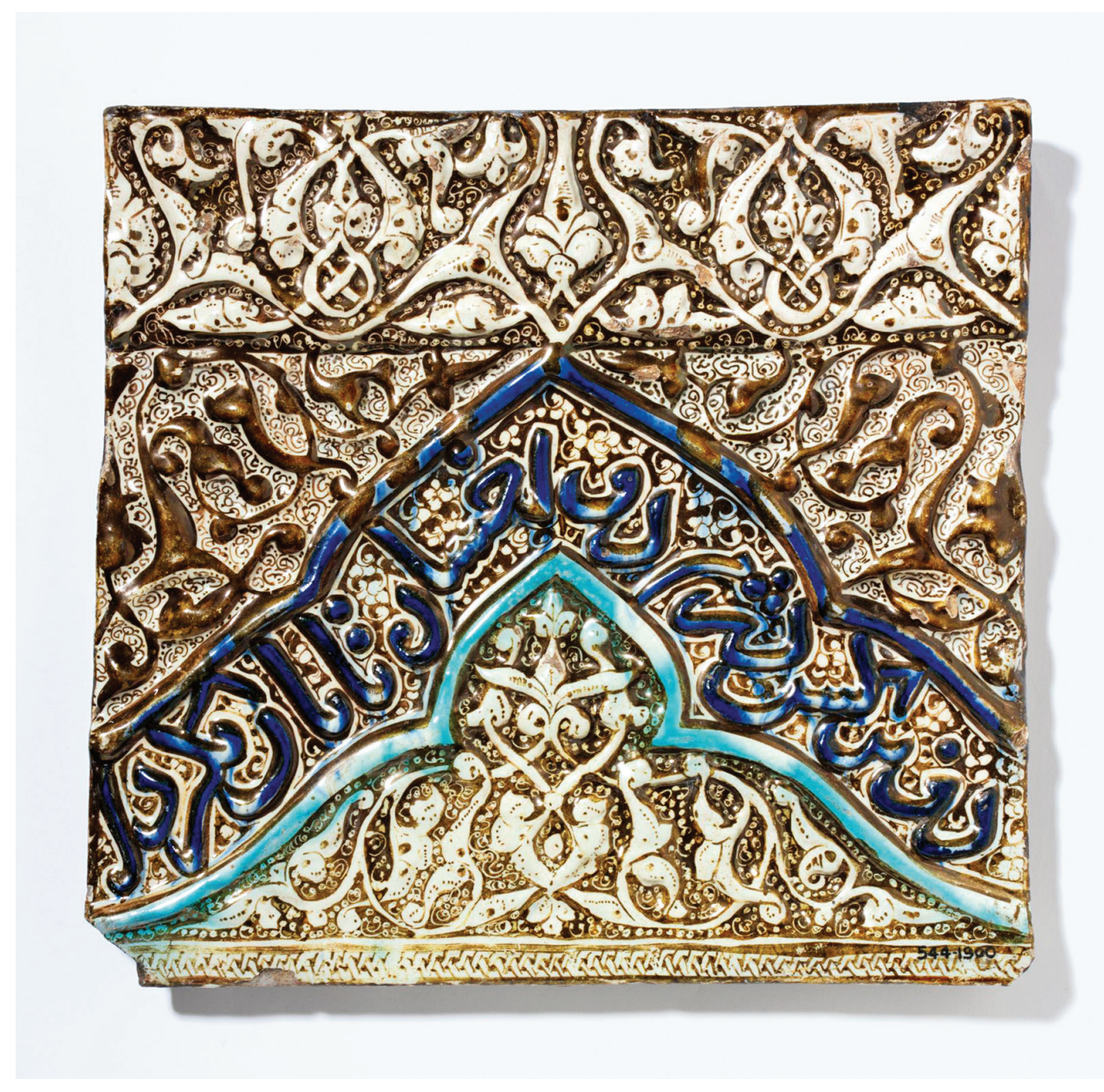

Frieze IV (Mélikian-Chirvani, 1996: Figure 12) distinguishes itself by spandrel motifs made of split palmettes and a lower band showing a tress pattern; this lower band is also seen on tiles from religious buildings. ${ }^{18}$ Only two tiles are listed (Cat. 4.1-4.2; Fig. 10). ${ }^{19}$

\section{$2.3 \quad$ The Smaller Series and Variations}

At least two slightly smaller series are also noticed. Frieze v $(26 \times 26.5 \mathrm{~cm})$ has an upper band with flowering bushes and parrots looking outward with one wing spread inward on the spandrels; the motif under the trilobe is also a floral stem. Six complete tiles and a fragment are identified (Cat. 5.1-5.7; Fig. 11).

Frieze VI (approx. $24 \times 25.8 \mathrm{~cm}$ ) has an upper band with split palmettes, flying birds similar to Frieze III on the spandrels, and no lower frieze; four tiles are listed (Cat. 6.16.4). However, the Brooklyn one apart (Fig. 12), ${ }^{20}$ the other three comprise fragments originating from different tiles, complicating identification of the quotes.

Noticeably, this tile model has also been used for Quranic friezes, as seen on a pair of tiles in Berlin's Islamische Kunst Museum. Surprisingly, another fragment from the same series was unearthed at Qalhat (Oman). ${ }^{21}$ Additional series with Arabic quotations (Q 2:255; Twelve Imams) exist but with a monochrome turquoise glaze. ${ }^{22}$ One example is at the Sèvres Museum (Fig. 13);23 a second one, highlighted with gold and colored slips, is in San Francisco's Asian Museum, although this coloring might be a modern addition. ${ }^{24}$ 

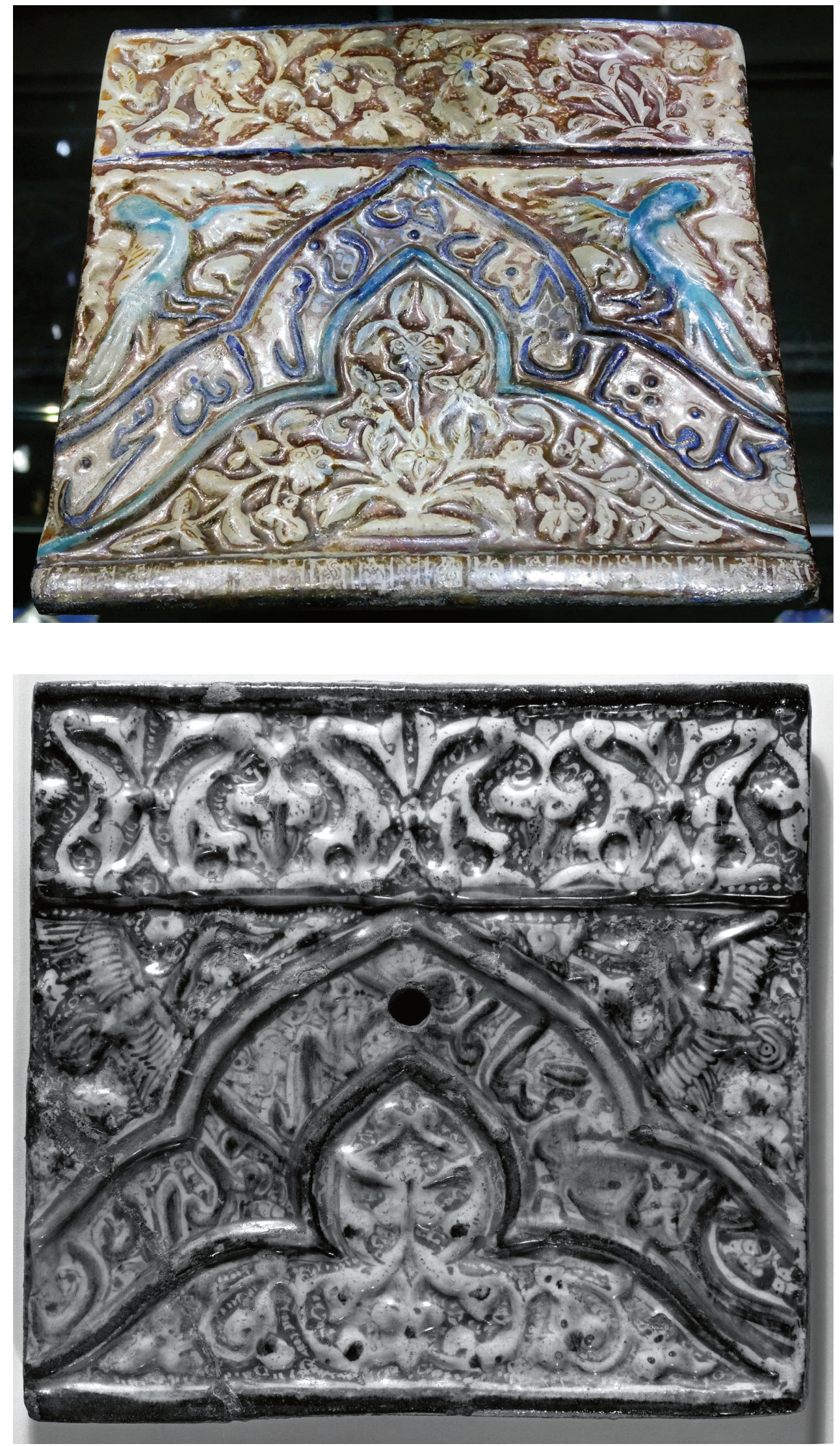

FIGURE 11

Tile from Frieze v; text: Golafshān konad chun sarāyad sokhan / He who sings these words will be scattering roses. (Cat. 5.7) unpublished. Tehran, Reza Abbasi Museum, no. 1739 (C) PHOTO ANAÏS LEONE
FIGURE 12

Frieze vi; text: [Sekandar biyâmad] be-shahr andarun / Alexander came inside the city. (Cat. 6.2) Brooklyn Museum, no. 42.212 .21

(C) CREATIVE COMMONS-BY 
FIGURE 13

Turquoise glazed tile with part of Q 2:255. MNC Sèvres no. 18291

(C) PHOTO YVES PORTER
FIGURE 14

Anepigraphic turquoise glazed tiles. Shangri La, DDF 48.356

(C) PHOTO YVES PORTER
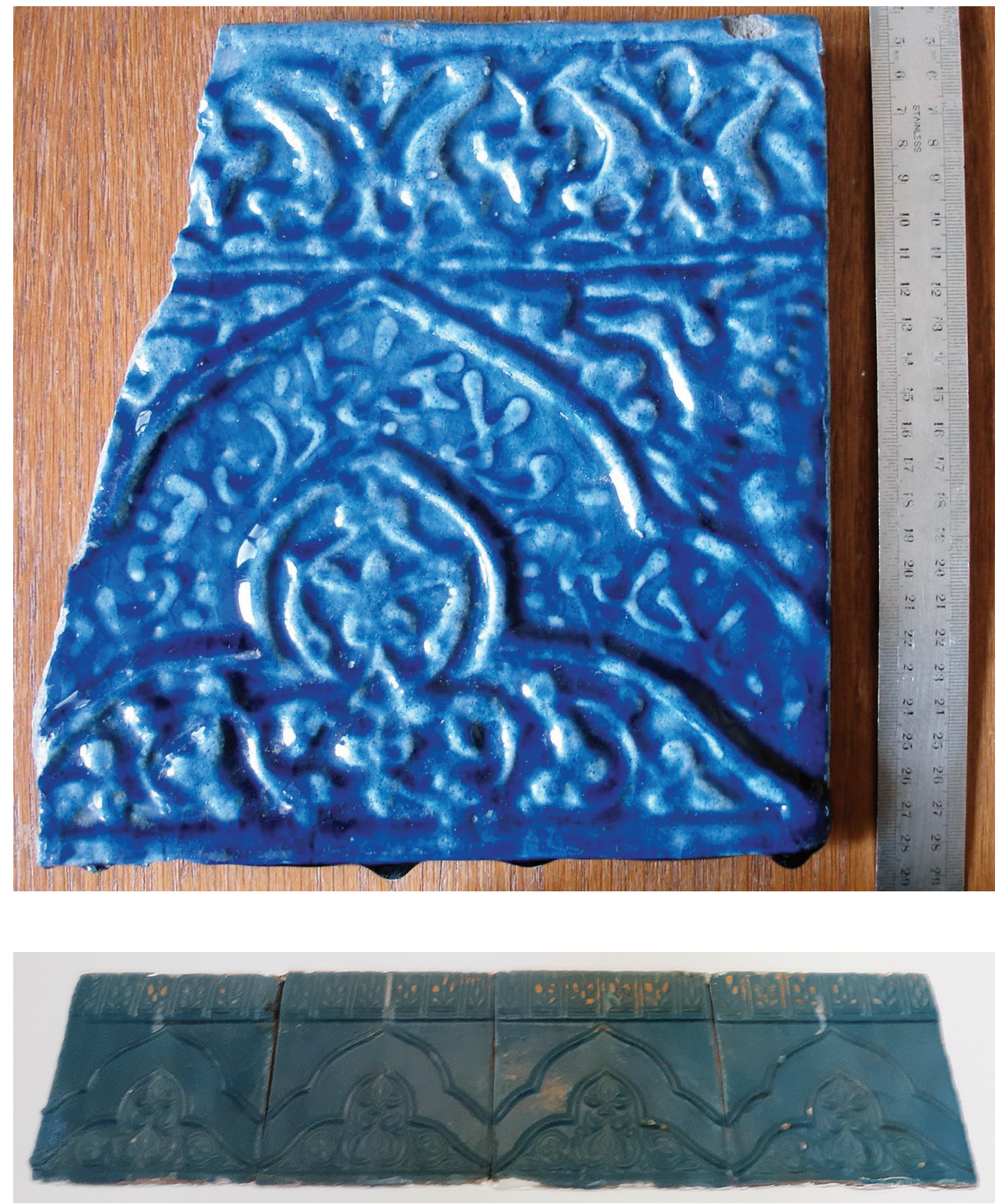

Moreover, a series of four plain molded, anepigraphic turquoise glazed square tiles, measuring approximately $26.5 \mathrm{~cm}$ each side, is preserved at Shangri La (Fig. 14). ${ }^{25}$

To this ensemble of friezes, Mélikian-Chirvani adds what he terms a seventh frieze (Mélikian-Chirvani, 1996: 20-1, Figure 13), represented by an isolated fragment (Cat. 7.1); the only available measurement (height: $20 \mathrm{~cm}$ ) does not allow determination of its complete size. The composition follows the general pattern of our Frieze IV, but the upper band is missing, and the lower band shows the "läm-alif" motif (whereas on Frieze IV, the lower band has a tress pattern).

\subsection{Frieze with Trilobed Arch and High-Relief Figures}

It is generally assumed that all the tiles with the trilobed arch scheme, the abovementioned Quranic frieze excepted, display verses from the Shah-nama. However, another frieze of larger dimensions (approx. $40 \mathrm{~cm}$ wide), with an epigraphic trilobed arch and enriched with molded human figures, is known through several tiles. While working on the one kept at the Chicago Art Institute, I determined that the quoted verse contained too many Arabic words to be from Firdausi (Fig. 15). ${ }^{26}$ Further research 


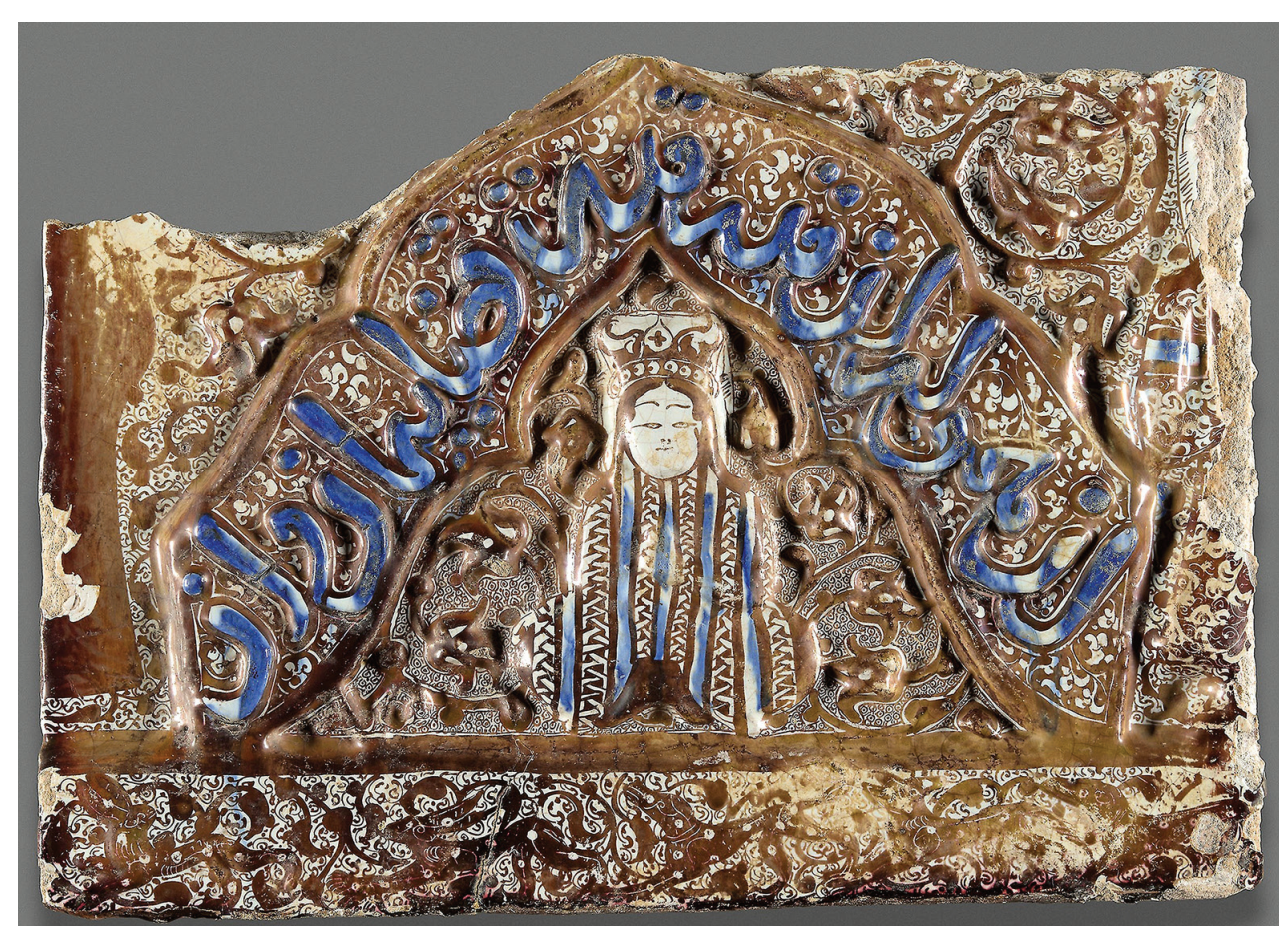

FIGURE 15

Tile with Anvari's qasida (Cat. 8.3); text: [ze Ir] ân hamvâr / ân qadr-e qodrat-e qazâ peymân va ân. Chicago Art Institute no. 1939.368

(C) CREATIVE COMMONS ZERO demonstrated that the quote belonged to a qasida by Anvari. ${ }^{27}$ This quote is particularly interesting as it describes, in a predictably bombastic style, the beauties of a Saljuq palace, about which nothing else is known. As mentioned in the Introduction, the subject of panegyrics composed purposely for the architectural decor has a prestigious precedent with the example of the Ghazni palace.

Five tiles have been so far identified, to which two slightly smaller ones and a pair of fragments can be added (Cat. 8.1-8.7). Unfortunately, besides that from Chicago, all the tiles from this series are composed of clumsily assembled fragments, with numerous fillings and repaints. Identified texts correspond to verses situated between lines 14 and 41 of the qasida.

It could be determined that each tile had a superior border decorated with split palmettes, interrupted in the center and both ends with seated figures in high relief. However, the only text-wise almost "intact" tile is the one at Chicago's Art Institute, this being now devoid of an upper band.

Another seated figure is placed under the trilobe, thus evocative of a prince sitting under an iwan; the lower frieze displays a row of hounds running to the left. Unfortunately, due to the fragmented state of most of the known examples, the reconstruction of their decor and textual quotations is difficult. This applies to the tiles in Khalili (Cat. 8.5), ${ }^{28}$ the Gayer-Anderson Museum (Cat. 8.1), and Sotheby's (Cat. 8.4).29 A fragment figuring half a tile, also showing some additions and fillings, was published in the Survey of Persian Art; ${ }^{30}$ it is now preserved at the Reza Abbasi Museum, Tehran (Cat. 8.2).

The same Iranian museum also keeps a second half-tile with a trilobe and high-relief figures, but of slightly inferior size, and with a lower band inscribed on a white background (Cat. 8.6; Fig. 16).

Another similar composite tile with a lower white band was sold in Paris in 2014 (Cat. 8.7). ${ }^{31}$ Thus, a whole "small" tile series with Anvari's qasida could have also existed (unless these "small" tiles are entirely composed of fragments). Additionally, several collections keep fragments or separated figures of seated persons, which probably once belonged to this model of tiles (Fig. 17). ${ }^{32}$ 
FIGURE 16

Two tiles with Anvari's qasida

(Cat. 8.2 and 8.6). Reza Abbasi Museum, Tehran

(C) PHOTO ANAÏS LEONE
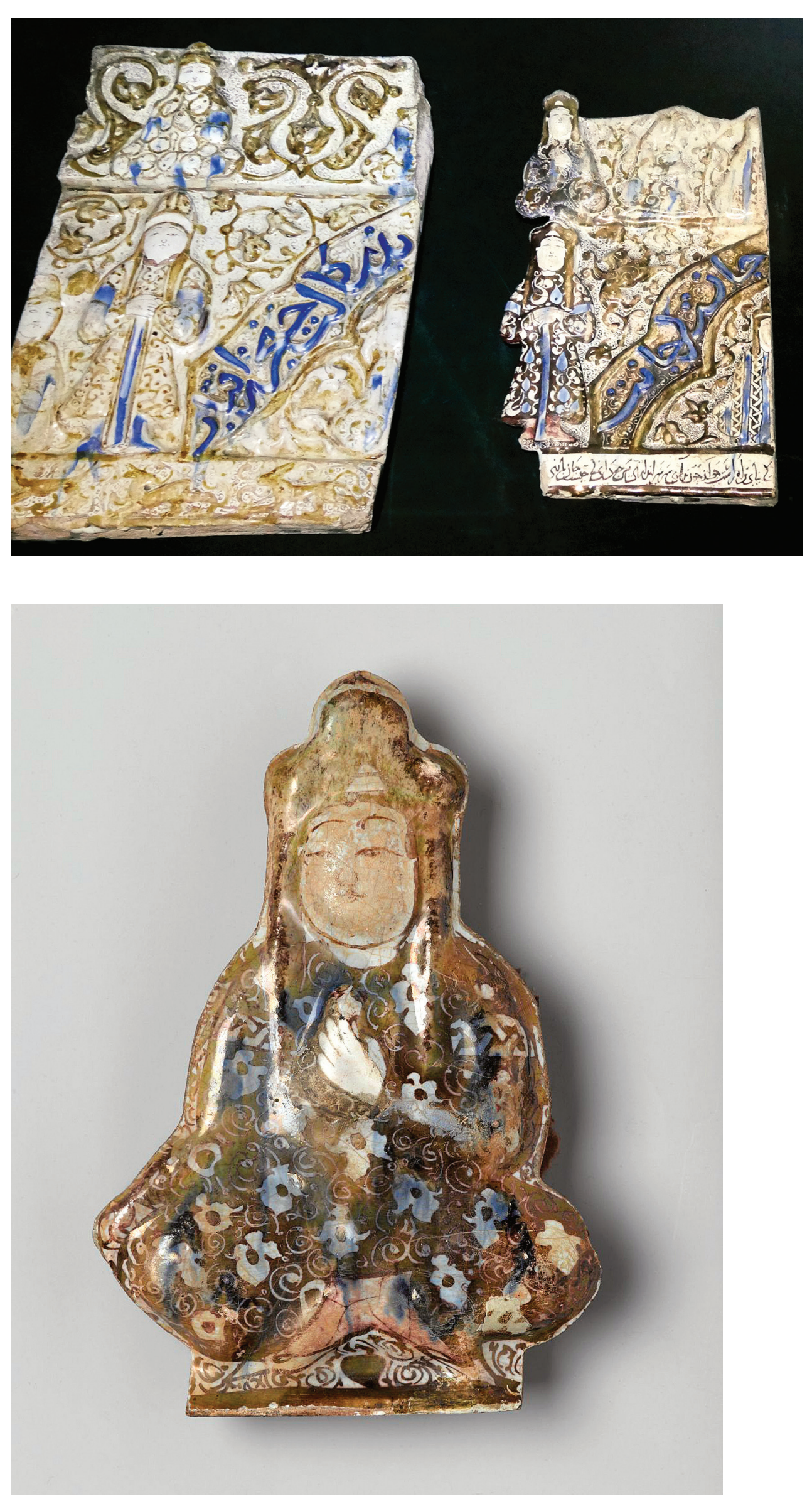

FIGURE 17

Figure presumably from a tile of Frieze 8 (Cat. 8.8). Brooklyn Museum no. 86.227.69

(C) CREATIVE COMMONS-BY 
In his 1996 publication, Mélikian-Chirvani clarified that every small variation in the decor of these series of tiles probably signified a different destination. It could be objected that minor differences (especially his Friezes III and VII, Mélikian-Chirvani, 1996: 12, Figures 5 and 13) are insufficient to embody a new series, being poorly represented.

Another puzzling example is suggested by two tiles in San Francisco's Asian Museum; although the tiles differ on their lower band ("lām-alif" vs. "pearl-string"), their verses are immediately consecutive in the Shah-nama edition:

\section{Hame kuh por lâle-o sonbol-ast ${ }^{33}$}

The whole mountain is covered with tulips and hyacinths.

монL jibi IV, p. 281, l. 2395b

Be pâliz bolbol benâlad hami ${ }^{34}$

In the meadow shall thus the nightingale complain.

монL jibi IV, p. 281, l. 2396a

Masuya does include both tiles in the same series (Masuya, 1997: 717, nos. 17-18). Regretfully, nothing is known about the origin of these tiles before their entering Octave Homberg's and subsequently the Avery Brundage Collection. ${ }^{35}$

The continuity of the upper and lower bands and other decorative details are remarkably coherent on friezes adorning pious foundations or shrines. It thus appears difficult to imagine that tiles intended for "royal" palaces would not display such coherence.

To conclude this section, and as stated by Mélikian-Chirvani, the knowledge of these tiles remains too fragmentary to make definitive assumptions. However, it can be assumed that each series of these now scattered fragments of tiled friezes once adorned various princely palaces. Although the only "relocated" example is "Frieze I" (allegedly from Takht-i Sulaiman, together with its twin at Eghvard), all of them may have been displayed similarly, as explained below.

From this survey emerges the concept of a type of decorative matrix that can be used in different places; this polyvalent localization appears congruent with the principle of an itinerant dynasty. Moreover, the various palatial locations surveyed hereafter weakens the preeminent position of Takht-i Sulaiman as a source for the dynastic legitimation.

Ilkhanid Palaces and Seasonal Residences: The Original Abode of the Tiles

The palatial architecture of the Ilkhans is remarkably undocumented by archaeological remains. Thus, Watson's list of buildings decorated with luster tiles only includes one palace, Takht-i Sulaiman, the summer complex of Abaqa Khan, rebuilt circa 1275 (Watson, 1985: 184, 188). Hence, most of the tiles, either epigraphic or decorated with figural patterns (dragons, simurghs, narrative scenes), now out of context, are repeatedly attributed to this palace. The archaeological surveys conducted in this area have yielded numerous examples of tiles, in various sizes, shapes, and motifs, and decorated with a wide range of techniques (monochrome flat or molded, so-called lajvardina, luster). However, as already mentioned, only some fragments belonging to the series studied here were found in situ.

Apart from Takht-i Sulaiman, the Ilkhans had many other dwelling places, starting with their "urban" residencies at Tabriz, Maragha, and Sultaniya. Hereafter, some 
FIGURE 18

Map with sites quoted in text (distance between Takht-i Sulaiman and Eghvard: $472 \mathrm{~km}$ ) (C) GOOGLE EARTH

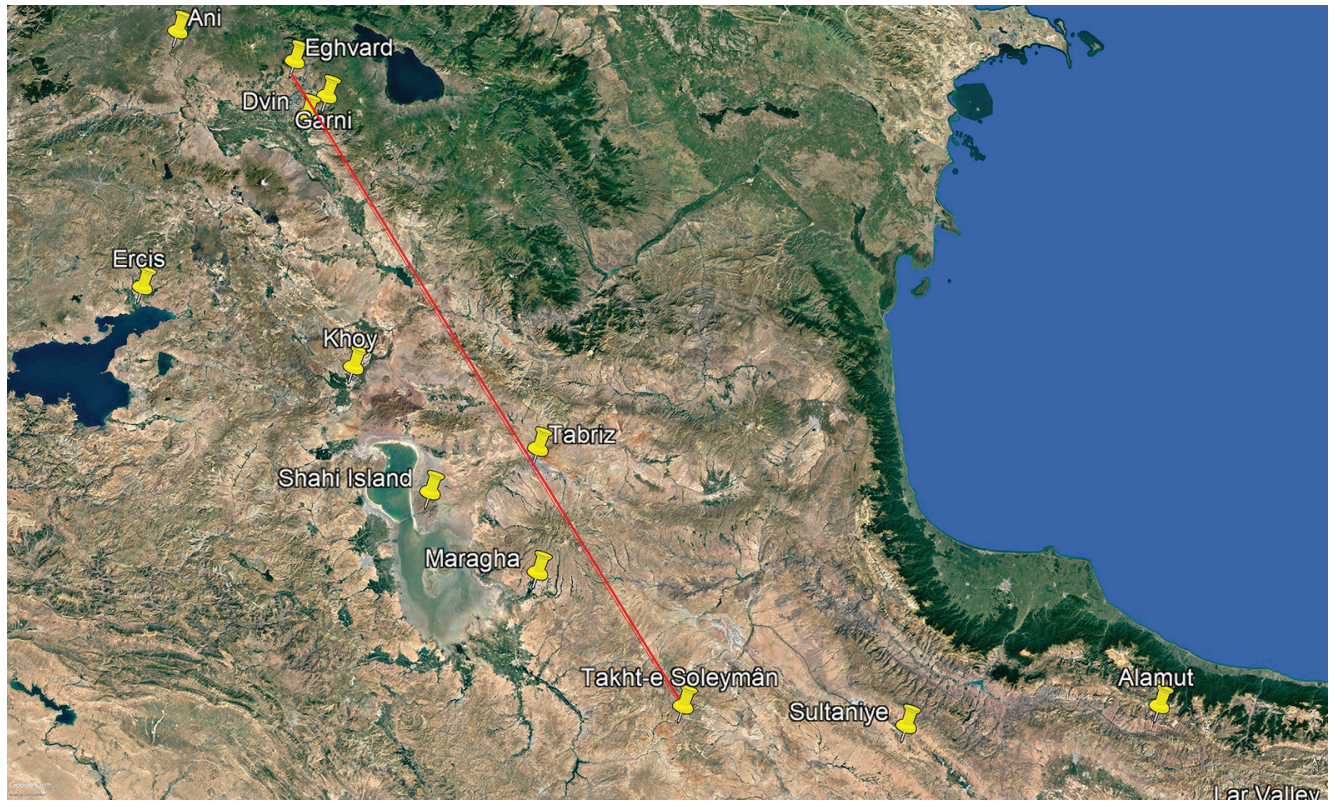

possible locations of Ilkhanid palaces are surveyed; whether these palaces were decorated with luster tiles will only be determined by future archaeological evidence.

In her study of the tiles from Takht-i Sulaiman, Masuya distinguishes those that were "excavated" in the site from "non-excavated" tiles originating from the art market. However, this distinction might be confusing here regarding some examples of reused tiles. Besides the fragments found in situ, another notable set of tiles alien to the art market is the ensemble reused at Eghvard Church, probably dating from the early fourteenth century (Donabédian and Porter, 2017; Fig. 4). Presumably, a Mongol palace decorated with luster tiles existed in Armenia, perhaps next to Dvin, Garni, or Ani. Some fragments have been found in various localities, although none of them corresponds to the trilobed scheme (Zhamkochyan, 1981: 129-33, 144-5, Pl. Xa, XI, XIa). Thus, the tiles reused at Eghvard could have been originally sited in one of these palaces (Fig. 18).

Among a series of luster shards recently found at Zulfabad, at least a small fragment (approx. $8 \times 7.5 \mathrm{~cm}$ ) can be added to the list of "excavated" tiles. However, as per the examples from Eghvard Church, it might have been a reuse (Sedighian, 2011: 1195, ill. 13$)^{36}$ (Fig. 19).

In addition to these, the storage rooms of several museums such as the Cité de la Céramique de Sèvres possess dozens of luster tile fragments also originating from "archaeological" contexts. At Sèvres, for instance, some of these fragments have old labels mentioning "Fouilles des ruines de Rheï, F. Méchin, 1866-67."37 It appears that "Rheï," mentioned on these labels, is a much-extended area, spreading a considerable distance from the present city of Rey, comprising Tappe Mil/Chal Tarkhan, Bibi Shahrbanu, and probably even the vicinity of Varamin. However, no Ilkhanid building that might have been decorated with luster tiles has been identified in this area.

Briefly, the proportion of "excavated" tiles is extremely low compared with the "nonexcavated" ones originating from the art market. However, potential locations for these sets of tiles are numerous; after identifying them mainly through written sources, these palatial locations should be archaeologically searched to ascertain whether they were at some point decorated with luster (or other) tiles. Hereafter is a survey of possible locations; apart from urban palaces, some hints on seasonal residencies, mainly located in the western parts of the Ilkhanid domains, are proposed. Due to a lack of sources, the central and southern parts of Iran are almost completely absent from this survey. 


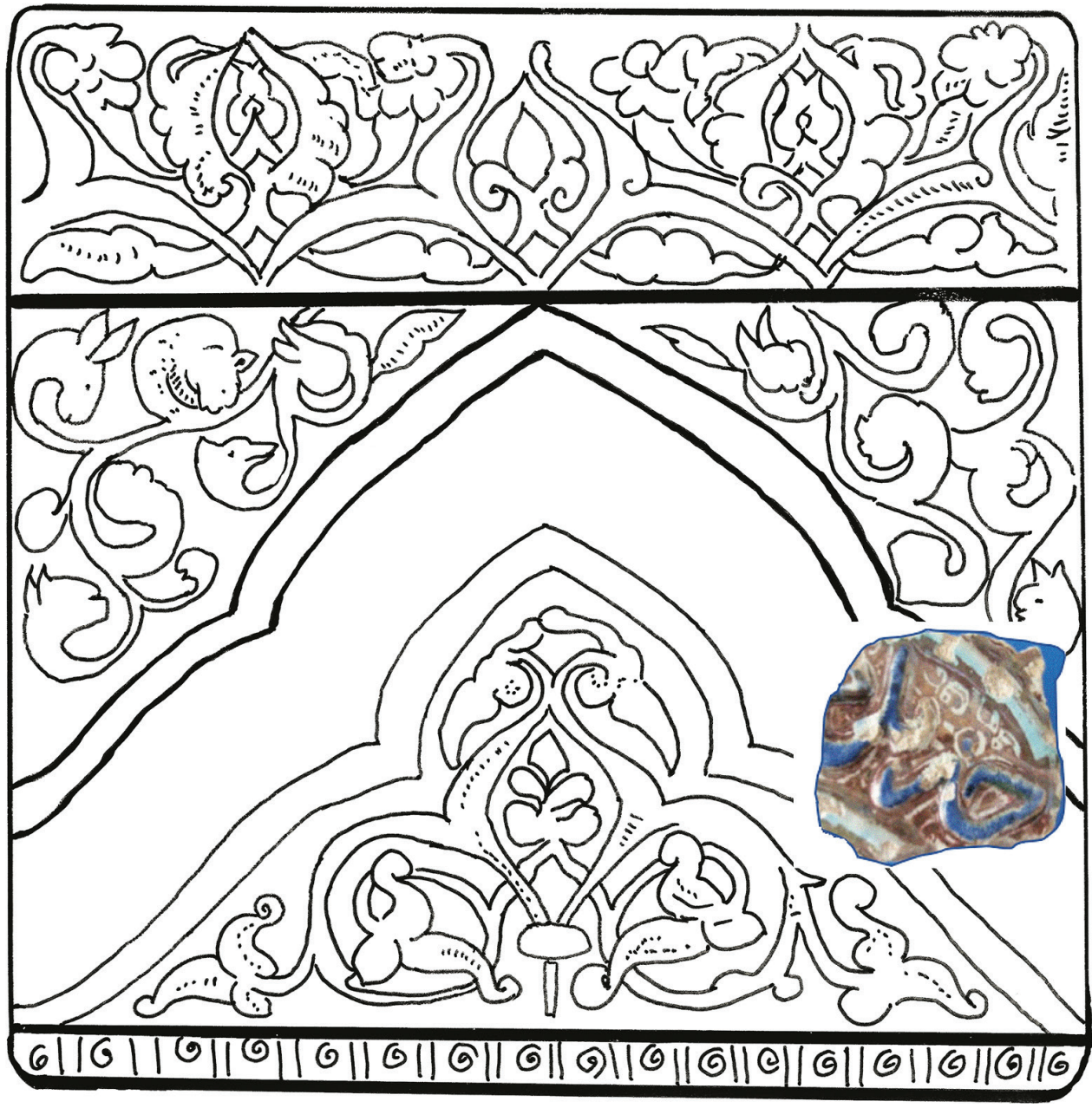

\subsection{Urban Palaces}

Before the Mongol invasions, several cities such as Baghdad, Tabriz, and Hamadan played important roles as political centers and retained some stature once peace was restored. Conversely, other former capitals such as Gurganj or Nishapur were razed to the ground. It appears logical that the Mongols relied on previous structures and persons for their administrative functions, especially during the first Ilkhans' reigns, when their "peripatetic" way of life (Melville, 2002: 45) strongly differed from that of their predecessors. However, this "royal nomadism" must probably be qualified. As Haneda (1989: 293) writes, Ilkhanid cities should be conceived as a "compromise" between the tribesmen's desire to erect their encampments outside the established cities and the Ilkhans' wish to build splendid monuments that impressed their subjects.

Basing her arguments on the seasonal mobility and customs of the Mongols, Masuya (1997: 177-8) proposes the following classification for their residencies: she names Tabriz, Maragha, Ghazaniya, and Sultaniya as "capitals of the ulus" (i.e., "country"), thus distinguishing them from "regional government centers" such as Baghdad, Isfahan, and Hamadan, and from "seasonal camps" (Chinese xingong). These are divided between summer (yaylaq) and winter (qishlaq) camps (Masuya, 2002: 76, Figure 80). It could be added that some "urban" settlements can comprise nonpermanent large encampments or a combination of permanent and temporary structures (Masuya, 2002: 77).

Baghdad suffered severe destruction, although some buildings such as the Madrasa Mustansiriya (built 1227) survived and remain standing. However, Baghdad's status, under Ilkhanid administration, appears to have fallen into a second rank, with Tabriz,
FIGURE 19

Fragment found at Zulfabad repositioned in a complete tile (Cat. 1.63)

(C) YVES PORTER 
Maragha, and later Sultaniya probably holding superior positions. Ata Malik Juvaini was appointed governor of Bagdad in 1259, a position he held up to his death in 1283 . Before his disgrace, he amassed a huge fortune; his dwellings in the former capital of the caliphs were stunning. His family also had a palace in Isfahan, described as a grand mansion with four iwans surrounding a courtyard (Blair, 1993: 241). Juvaini acted as protector of the great Baghdadi calligrapher Yaqut al-Musta'simi (c. 1221-98), a survivor of the destruction of the Abbasid capital. The production of high-quality manuscripts in this city also indicates the recovery of high-life standards. The Ilkhans occasionally dwelt in Baghdad; thus, Abu Said usually spent winter in this city (Melville, 2002: 45). However, the archaeological remains of Ilkhanid palaces in this location remain unknown.

Concerning Tabriz, Mustawfi (1919: 79) writes:

In Mongol times, when this city had become the capital of the kingdom, the population here greatly increased, and they began to build many houses outside the city limits, until at length at each gate there was a suburb as great as the city itself had originally been. These suburbs therefore Ghazan Khan proceeded to surround by a wall, which should encircle also all the gardens and their buildings.

In and around Tabriz, several palaces were built: Arghun (r. 1284-91) founded Arghuniya, his palatial city, later called Shenb, on a western suburb of Tabriz; "lofty houses" are mentioned in this location. ${ }^{38}$ His son Ghazan (r. 1295-1303) had his own complex (Ghazaniya, where his mausoleum laid) built next to it; he is also credited for building a "palace or administration building ... and a garden palace" (Wilber, 1955: 190). Additionally, Wilber notes, without further details, that fragments of tiles have been found in the ruins of the Ghazaniya (Wilber, 1955: 124-6, no. 27; see also Watson, 1985: 188).

Apparently, Uljaytu (r. 1303-16) also used the Shenb palace but was also busy building palaces and residential quarters at Sultaniya (see below). The vizier and historian Rashid al-Din Fazlallah (d. 1317) also had his foundation of Rab-i Rashidi built in this area, although "its endowment deed does not indicate that the vizier had a residence there" (Masuya, 2002: 79). ${ }^{39}$

The calligrapher 'Abdullah Sayrafi (d. after 746/1345-6) was from Tabriz; Qazi Ahmad Qomi states that he was "a master in the making of inscriptions on glazed tiles (kashi). His writing is on the buildings of the capital" (Qazi Ahmad, 1959: 62). Unfortunately, none of his monumental inscriptions, nor those of his pupil Hajji Muhammad Bandgir, have survived (Soucek, 1982).

Apart from "royal" dwellings and foundations, the city of Tabriz acknowledged real prosperity during Ilkhanid rule, notably due to its role in international trade. ${ }^{40}$ Present excavations, particularly on the Rab'-i Rashidi area, could soon yield more information on Tabriz's secular buildings. ${ }^{41}$

\subsection{Maragha}

Wilber narrates, "After the return of Hulagu from Baghdad to Iran in 656/1258, he settled at Maragha and soon ordered an observatory built there from plans prepared by Nasir ad-Din Tusi" (Wilber, 1955:107). His first settlement was an encampment. By 1340, when Hamdallah Mustawfi wrote his Nuzhat al-qulūb, the observatory building had fallen into ruins (Mustawfi, 1919: 88).

Wilber notes that Arghun built a "Church adjacent to a palace known as 'Gate of the Kingdom," but laconically adds, "site of the palace not known" (Wilber, 1955: 190). Arghun and Ghaykhatu (r. 1291-95) built or rebuilt several churches in and around Maragha; Ghazan completed the monastery of Saint John the Baptist in the same town 
(Wilber, 1955: 190). The existence of a perennial palace at Maragha is thus not ascertained by written sources.

Among the constructions credited to Hulagu, Wilber adds the site of Shahi Island ( 80 $\mathrm{km}$ northwest of Maragha, as the crow flies), on Lake Urmiah, as the probable location for his treasure house and burial place (Wilber, 1955: 108-9); however, no proper built space dating from this period has been found yet. ${ }^{42}$

\subsection{Sultaniya}

The city of Sultaniya, previously known as the Ilkhanid summer camp of Khonkur Öleng (Masuya, 2002: 81), developed inside a walled stronghold measuring circa $325 \mathrm{~m}$ north to south and $290 \mathrm{~m}$ east to west. Uljaytu's monumental mausoleum occupies part of the city's southwestern quadrant; recent excavations have revealed the remnants of other structures on the eastern side of the funerary complex (Blair, 2014: 128-9). Other buildings have also been cleared, revealing a monumental pathway facing the northern gate, which was probably bordered by shops, in the manner of Bazar alley (Hatef Naiemi, 2020: 6-8; Fig. 20). Hafiz-i Abru, a fifteenth-century historian, reports that Uljaytu built an enormous palace with a huge iwan, although the current state hardly shows any such remains (Masuya, 2002: 81). ${ }^{43}$ Recent archaeological surveys undergone in the area have also yielded hundreds of luster tile fragments, although their original exact location and typology are not yet accurately described (Hatef Naeimi, 2020; Irib News Agency, 2020).

Around 1340, Mustawfi wrote, "There are at the present time so many great buildings in Sultaniya, that, except for Tabriz, the like thereof is seen in no other city" (Mustawfi, 1919: 61). However, besides the mausoleum, little is known about other monuments, such as the churches and monasteries of Sultaniya. Nonetheless, a remarkable Armenian manuscript of the Gospels, written and illuminated by Mkhitar Anetsi, was copied in this town in $1356-7 \cdot{ }^{44}$ Its miniatures and illuminations show a strong local artistic influence,

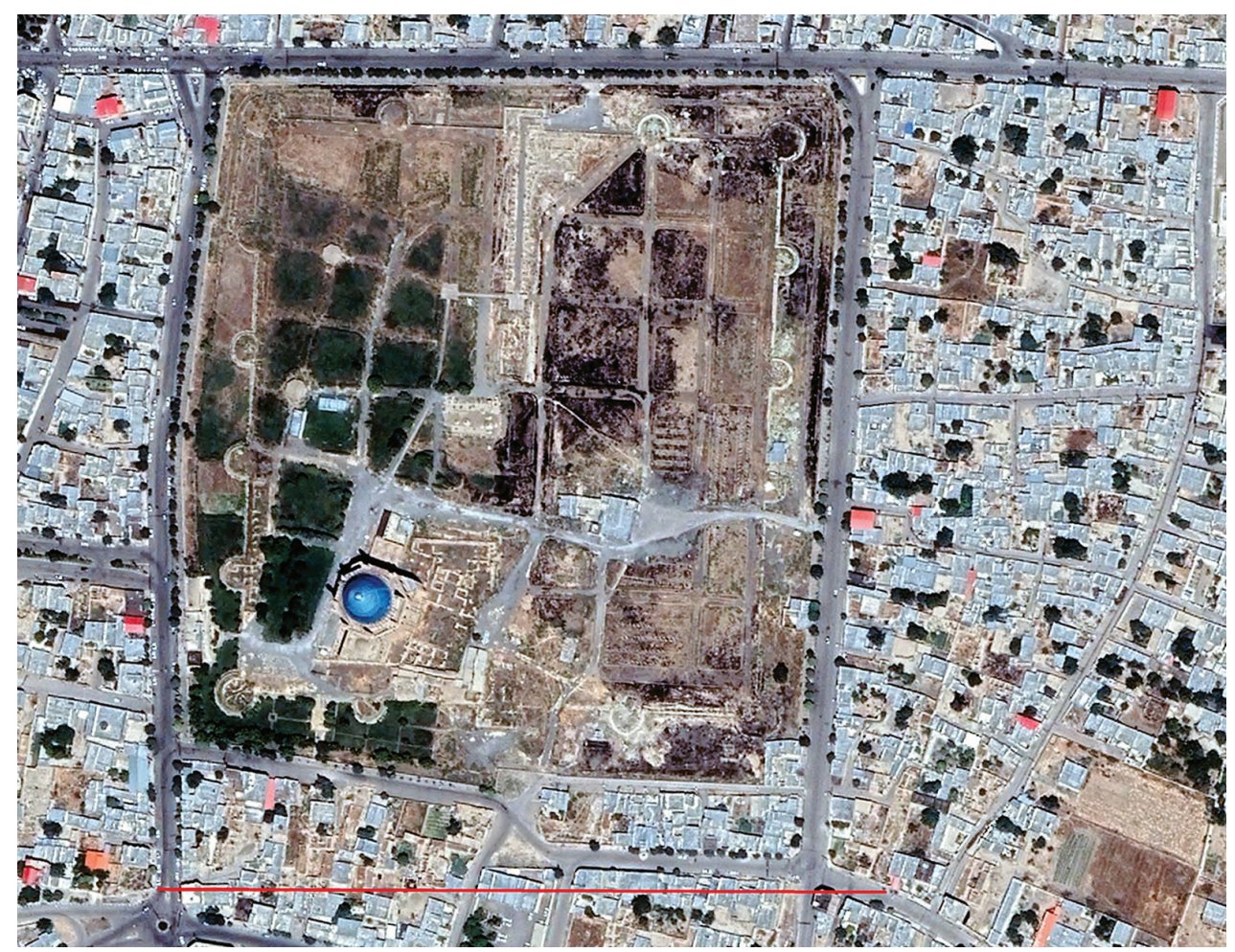

FIGURE 20 Sultaniya (in red: $400 \mathrm{~m}$ ) (c) GOOGLE EARTH 
thus probably implying that in the mid-fourteenth century, Sultaniya retained some cultural importance, together with strong connections with "outer" Armenia.

As stated by Hatef Naiemi (2O2O), large parts of the city remain to be explored; further research might thus provide information on Sultaniya's palaces and their decoration.

Sujas, 5 leagues south of Sultaniya, is mentioned by Wilber as the location of a palace built by Arghun; he probably relied on Mustawfi for this assertion (Mustawfi, 1919: 61; Wilber, 1955: 190). However, Mustawfi only mentions the tomb of Arghun, which was built in a secret place near this locality. Wilber's mistake is probably explained because Mustawfi adds immediately after Arghun's resting place the description of the "city" of Saturiq, Takht-i Sulaiman (Mustawfi, 1919: 69). ${ }^{45}$ Besides this apparently mistaken reference made by Wilber, I have found no evidence of any palace at Sujas.

\subsection{Seasonal Residencies}

The seasonal mobility of the Ilkhans is well-attested by the written sources, the residencies thus varying from summer to winter. This mobility implies that some of the nonpermanent residencies were built with light materials, such as wood and textiles, while more "permanent" ones were made of bricks and stones and often decorated with tiles.

Besides Takht-e Sulaiman, Ilkhanid chronicles mention several other royal residencies. Wilber lists some summer dwellings in his "Supplementary Catalogue of Architectural Monuments Known Only through Literary References," in which several indications are given on this subject (Wilber, 1955: 190-1). Unfortunately, this author provides no textual reference supporting his affirmations. Additionally, as mentioned before, there was probably one (or more) palace in Armenia.

\subsection{Takht-i Sulaiman/Saturiq/Shiz}

As the only located, still standing Ilkhanid palace, this yaylaq site has been abundantly studied and commented on. Mélikian-Chirvani devoted several papers to its symbolic relevance in the process of legitimizing the Ilkhanid power. ${ }^{46}$ It likewise forms the core of Masuya's thesis; an updated synthesis of archaeological surveys on this site has been proposed by Huff (2006).

As previously noted, although many tiles have been found on this site, only some fragments belong to the series studied here. Moreover, their precise location on the palace walls is unknown (see Layout, setting, and contents).

In a different context, it can be added that recent studies on ancient gold-mining in the area have also been published (Momenzadeh et al., 2016). ${ }^{47}$ They concern the region situated north of Takab, particularly in the valleys of Agh-Darreh and Zarshuran, both adjacent to Takht-i Sulaiman (Fig. 21). Interestingly, the ruins of a small fort have also been traced in the vicinity of Zarshuran deposits, thus probably implying the presence of a small garrison. Both these deposits, showing evidence of activity during antique and medieval periods, are today considered important for gold-mining and are (or will soon be) operating;48 the need for further archaeological research in this region is thus urgent. Gold panning at Shiz was already noted by some ancient authors, such as Abu Dulaf in the late tenth century (Abu Dulaf, 1955: 2 (text), 31 (trans.); Allan, 2001).

Hence, without entering the details of the Ilkhanid occupation of Takht-i Sulaiman's site here, it is probable that beyond the symbolic reprise of an ancient site, its importance as an economic relay in the mining of precious metals cannot be ignored. 


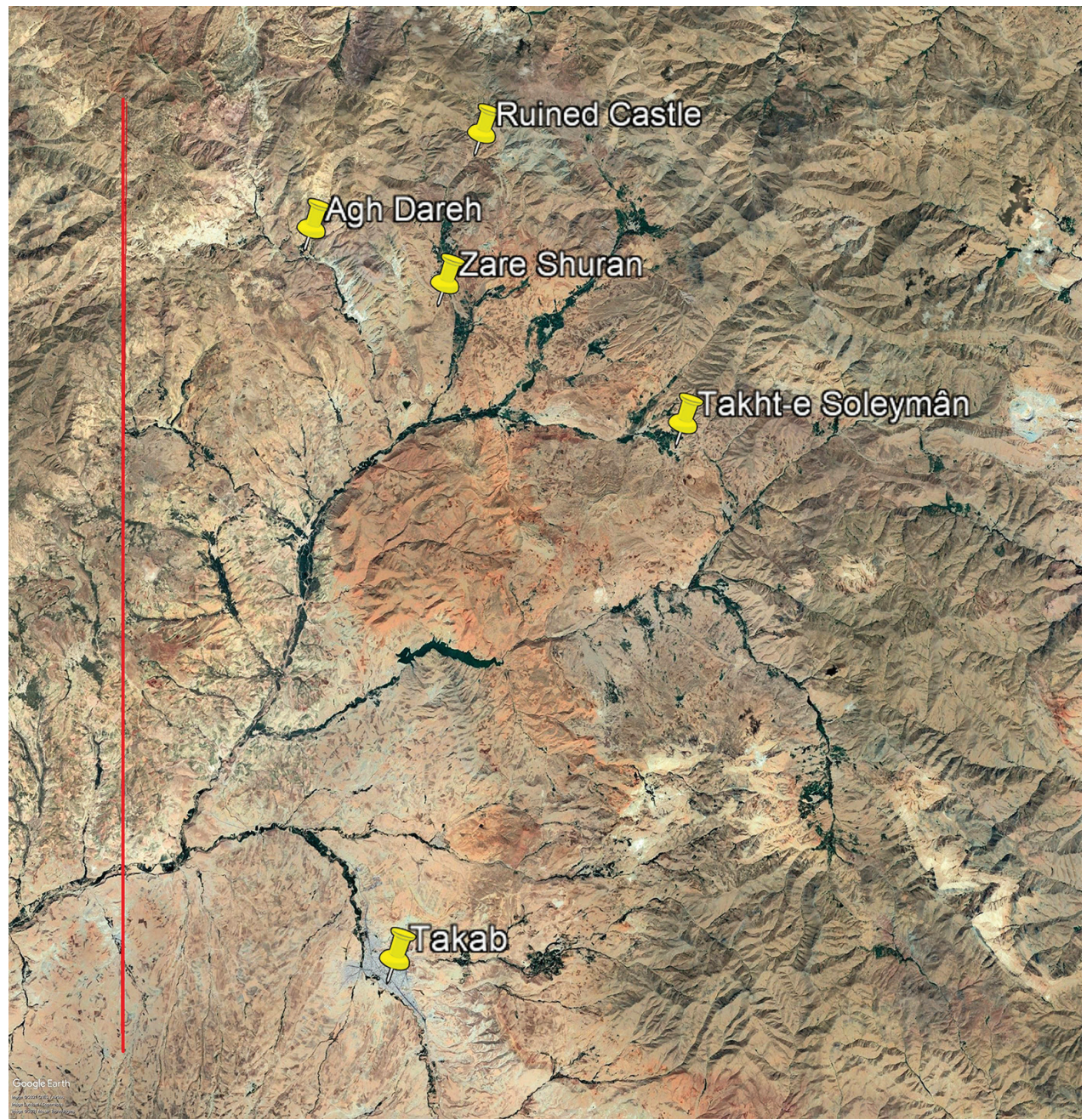

\subsection{Other Ilkhanid Seasonal Residences}

Although several other sites are mentioned in the sources as locations of seasonal "palaces," these show no recognizable architectural trace.

Among these, the first group of sites is located to the west of Lake Urmiah, between the town of Khoy and the Alataq yaylaq, in the mountains north of Lake Van (Fig. 22). Although these sites were originally bound to the summer yaylaq itineraries, other activities such as the political marking of the territory might not be excluded.

Thus, Wilber mentions a castle at Khoy built for Hulagu (r. 1256-65), before 1265, together with a Buddhist temple (Wilber, 1955: 190). However, although Mustawfi notes the presence of "many gardens," these buildings are not mentioned in his description of the town (Mustawfi, 1919: 86).

Approximately $150 \mathrm{~km}$ to the west of Khoy, as the crow flies, stands Lake Van; to its north are some mountain ranges amongst which is Alataq, "the preferred royal yaylaq" (Smith, 1999: 43). According to the Armenian chronicler Stepannos Orbelian (c. 12501303), "[King Smbat Orbelian] was sent by Hülegü Khan ... to Ala Taq (Daŕn Dasht) to assist the latter in building a large royal palace."49 According to Wilber, this castle was probably made of wood (Wilber, 1955: 19o: "Castle, probably of wood, at Ālātāgh (Ala Dagh), just prior to 1265 "). However, at a later date, Mustawfi writes, in his description of the Akhlat province, that Alataq is "A district with excellent pasture-lands and many hunting-grounds. Arghun built a palace here, and was wont to sojourn here most of the
FIGURE 21 Takht-i Sulaiman and north of Takab (in red: $40 \mathrm{~km}$ ) (C) GOOGLE EARTH 
FIGURE 22

From Lake Urmiah to Lake Van (400 km) (C) GOOGLE EARTH

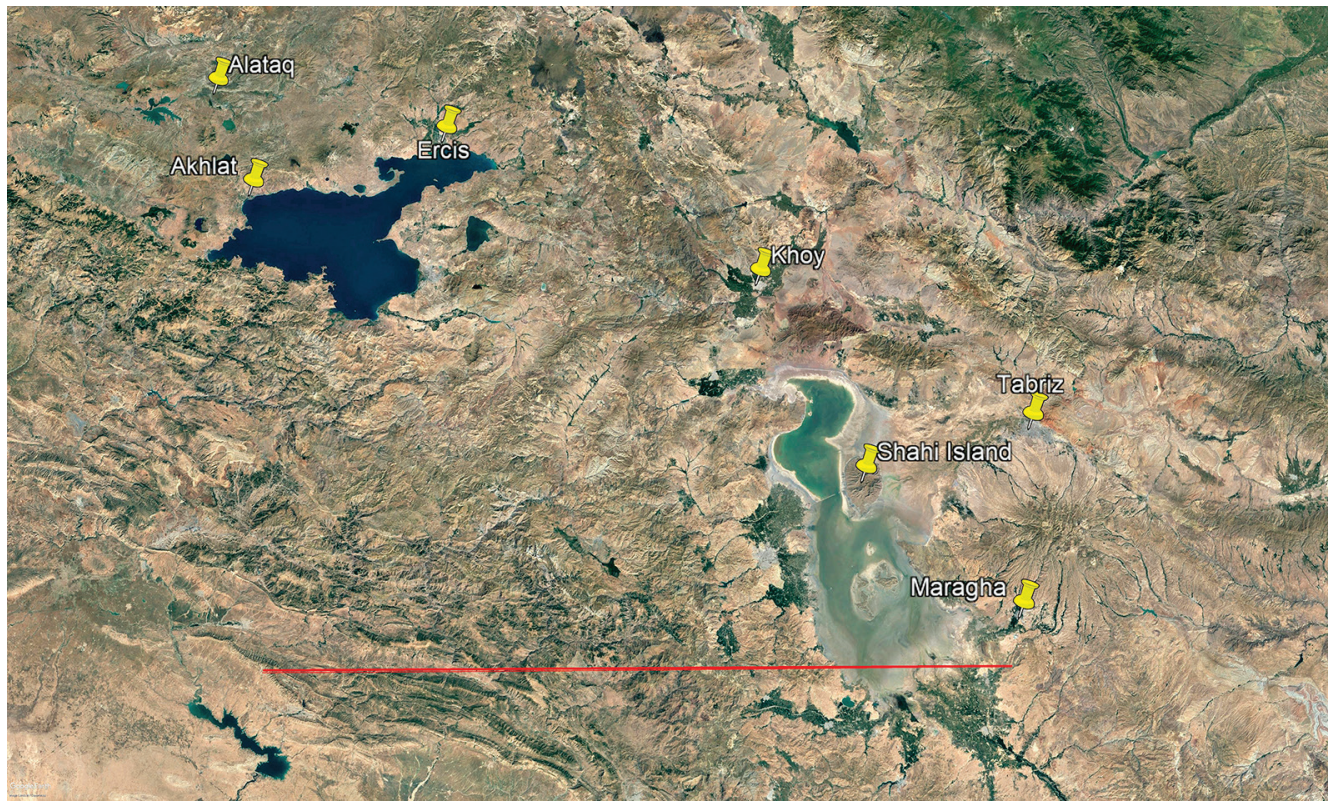

summer" (Mustawfi, 1919: 10o; see also Smith, 1999: 43-4, and his Map 1). This later mention could imply that the first wooden or seasonal residence was replaced by a second more perennial one. Wilber adds that Ghaykhatu also had a church built there (Wilber, 1955: 190). ${ }^{50}$

The town of Ercis stands on the northeastern shore of Lake Van. According to Mustawfi, "The Vazir Khwajah Taj-ad-Din 'Ali Shah of Tabriz fortified it [i.e., the town], and now it has a strong castle" (Mustawfi, 1919: 100, 175: Itinerary from Tabriz to Erzerum). ${ }^{51}$

The northwestern territories of the Ilkhans, and especially Greater Armenia, had been the subject of varied relations with the Armenian elites. Several references are made to a palace built by Hulagu in the vicinity of Dvin or Garni, although its identification remains vague. ${ }^{52}$ Additionally, some of the Armenian lords might have benefited either from the liberality of Ilkhanid power or the outcome of plunder to build palaces decorated with luster tiles, as suggested by the above-mentioned archaeological findings. However, besides the examples from Eghvard, none of these Armenian finds yet displays any fragment with the trilobed scheme.

The eastern side of the Ilkhanid domains is less documented than the western one as far as palace architecture is concerned. ${ }^{53}$ Wilber mentions a "Summer palace, called 'Arghun's Kiosk' at Lar, near Mount Damavand," without other references (Wilber, 1955: 19o). The Lar Valley has notably been the site of yaylaq up to the Qajar period (Hourcade, 1977). Besides a stone-built caravanserai, probably dating to the Safavid period, a cemetery, and several other ruined structures surrounded by an area of un-surveyed rubble, no traces of a "palace" were recorded in the valley up to now (Figs. 23-24). However, recent surveys in locations situated up the valley (hill LT123, so-called Khoshi-Khaneh) have convincingly located the traces of an Ilkhanid palace. This site had already been excavated during the reign of Nasir al-Din Shah, yielding several examples of luster tiles, some of which were housed in Tehran's Muze-ye Melli. ${ }^{54}$ Up to now, none of the excavated tiles follows the pattern of the ones studied here. Although further research is needed, the Lar summer palace's existence is now ascertained.

A hint indicating the existence of a now vanished palace, situated in the vicinity of Damghan, was proposed as early as the 188 os (E'temād al-Saltana, 1976). ${ }^{55}$ The stars and crosses tiles from Imamzadeh Jafar in Damghan, now dispersed among various 

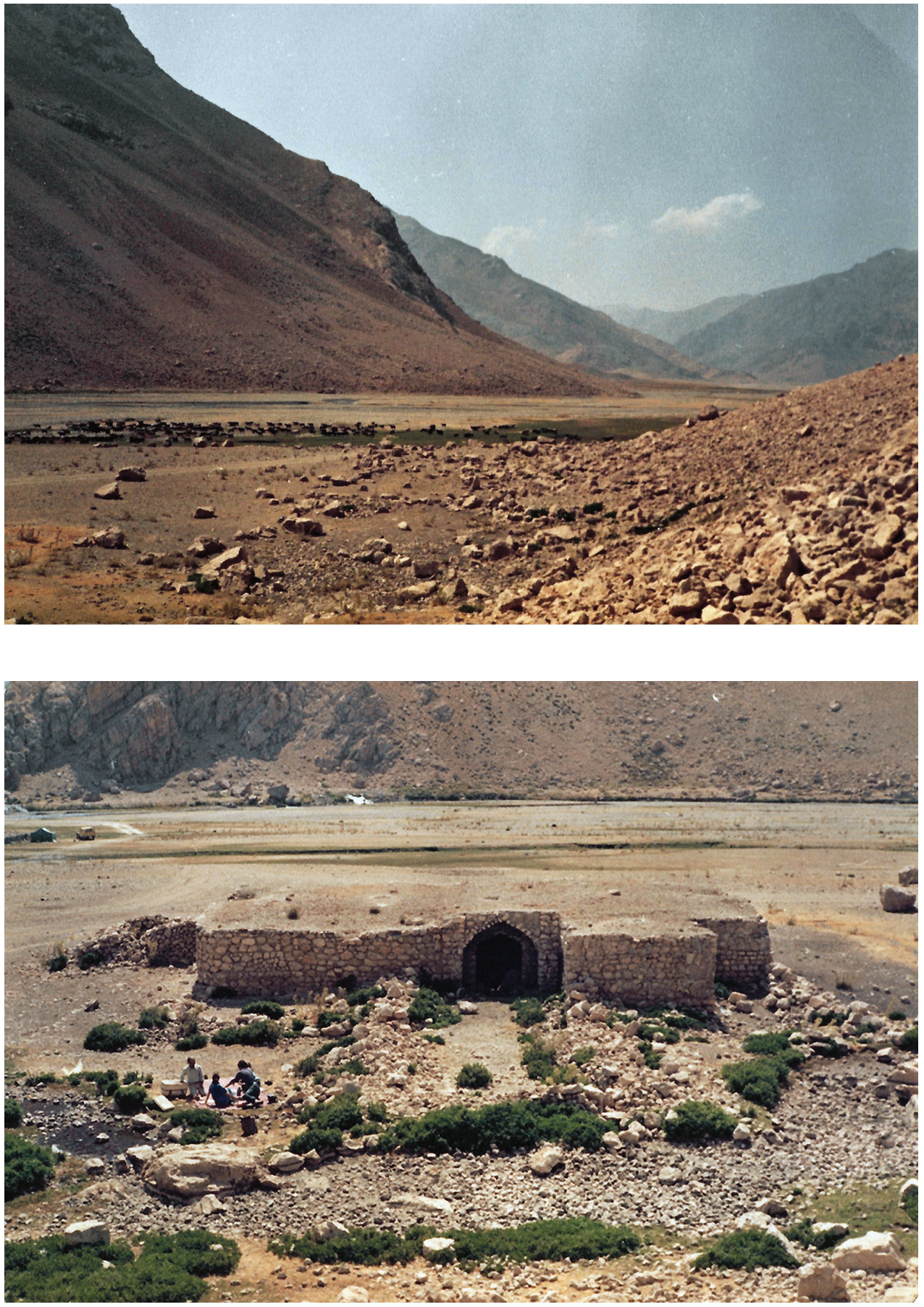

collections, could be an example of the reuse of tiles originating from a palatial residence. Approximately $24 \mathrm{~km}$ north of Damghan lies the Cheshme 'Ali site; a palace built by Fath 'Ali Shah in 1802 still overlooks a large pond there. Although no evidence of earlier buildings is known, this rather large freshwater spring located at the base of a hill appears an ideal location for a summer residence (Alizadeh, 1990). However, archaeological prospections are required to ascertain the occupation of this site during the Ilkhanid period.

Simultaneously and significantly, several authors mention the gold-mining site of Kuh-i Zar in the vicinity of Damghan; Abu al-Qāsim (1966: 216) writes that he saw it himself. This site is situated about $80 \mathrm{~km}$ south of the city, and contrary to the mines
FIGURE 23

Lar Valley, August 1982 (C) PHOTO YVES PORTER

FIGURE 24

Caravanserai at Lar Valley, August 1982 (C) PHOTO YVES PORTER 
north of Takab, it is no longer active. One could wonder if, similarly to Shiz/Takht-i Sulaiman, the gold mine near Damghan could have been linked with a palace.

Both urban and seasonal settlements embody the presence of the ruling elites and symbolize their power. Thus, the palaces served not only as a residence but also as landmarks in the territorial network. Their economic importance, not only for cattle transhumance but also when the sites are related to the extraction of precious metals, cannot be underestimated.

Moreover, and as already noted, Mélikian-Chirvani has evidenced that the friezes with verses from the Shah-nama originated from several different palaces. Thus, the series of tiles represent the first evidence for the existence of these otherwise unknown palaces. However, further surveys, both in the written sources and on archaeological fields, are needed to confirm the matching between scattered tiles and Ilkhanid palaces. At least, the domain of Ilkhanid tiles in palace decoration, both urban and seasonal, now appears much wider than previously depicted.

\section{$4 \quad$ Layout, Setting, and Contents}

Where in the palaces and according to what schemes the tiles were positioned are questions that can only be answered hypothetically. Additionally, the meanings of the quoted excerpts in the context of their original setting allow questioning of the suitability of the tiles for their supporting walls.

\subsection{General Layout}

Most of the known tiles display only a single hemistich of Firdausi's epic; ${ }^{56}$ finding a pair of tiles with matching or rhyming hemistiches is exceptional. However, this appears among the examples preserved at Eghvard Church. The tiles were originally arranged in pairs to form a distich, constituting a continuous frieze at some distance from the floor, at eye level. These square tiles were set above a dado decorated with stars and crosses, as in Natanz's funerary chamber, for instance. ${ }^{57}$ Naumann proposed a schematic drawing of the arrangement of the dado and frieze of the Northern Octagonal Room. However, the size of the square tiles $(35 \mathrm{~cm})$ indicates a format larger than the trilobed arch series (30 cm) (Naumann, 1977: Abb. 66, "Wanddekoration im Nordoktogon"). This type of scheme appears on a page from the Great Mongol Shah-nama, Faridun Goes to Iraj's Palace and Mourns. ${ }^{58}$ It shows the tiled dado of Iraj's palace, composed of hexagonal deep-blue tiles painted with golden motifs; above this runs a series of almost square tiles painted in the same hues and displaying flying geese, with a zig-zagging upper edge (Fig. 25). ${ }^{59}$ Hexagonal so-called lajvardina tiles have been recovered from Takht-i Sulaiman. ${ }^{60}$ Another example of a dado, illustrated in the same manuscript, is depicted in the painting, Sindukht Becomes Aware of Rudaba's Actions. ${ }^{61}$ It comprises six-pointed stars and rhomboids painted in deep blue and gold. In both examples, the use of gold could be reminiscent of the luster tiles combined with lajvardina elements.

A pending question is whether the matching pairs of tiles were displayed side by side with other pairs of the same series or if they were intersected with other tiles such as "figural" ones. The similarity between some upper bands, such as those in Frieze III, with tiles having a figurative decor is puzzling and could suggest that the figurative tiles alternated with couples of inscribed tiles. A tile in the Victoria and Albert Museum featuring a lion attacking a bull has measures allowing this parallel ${ }^{62}$ (Fig. 26). 

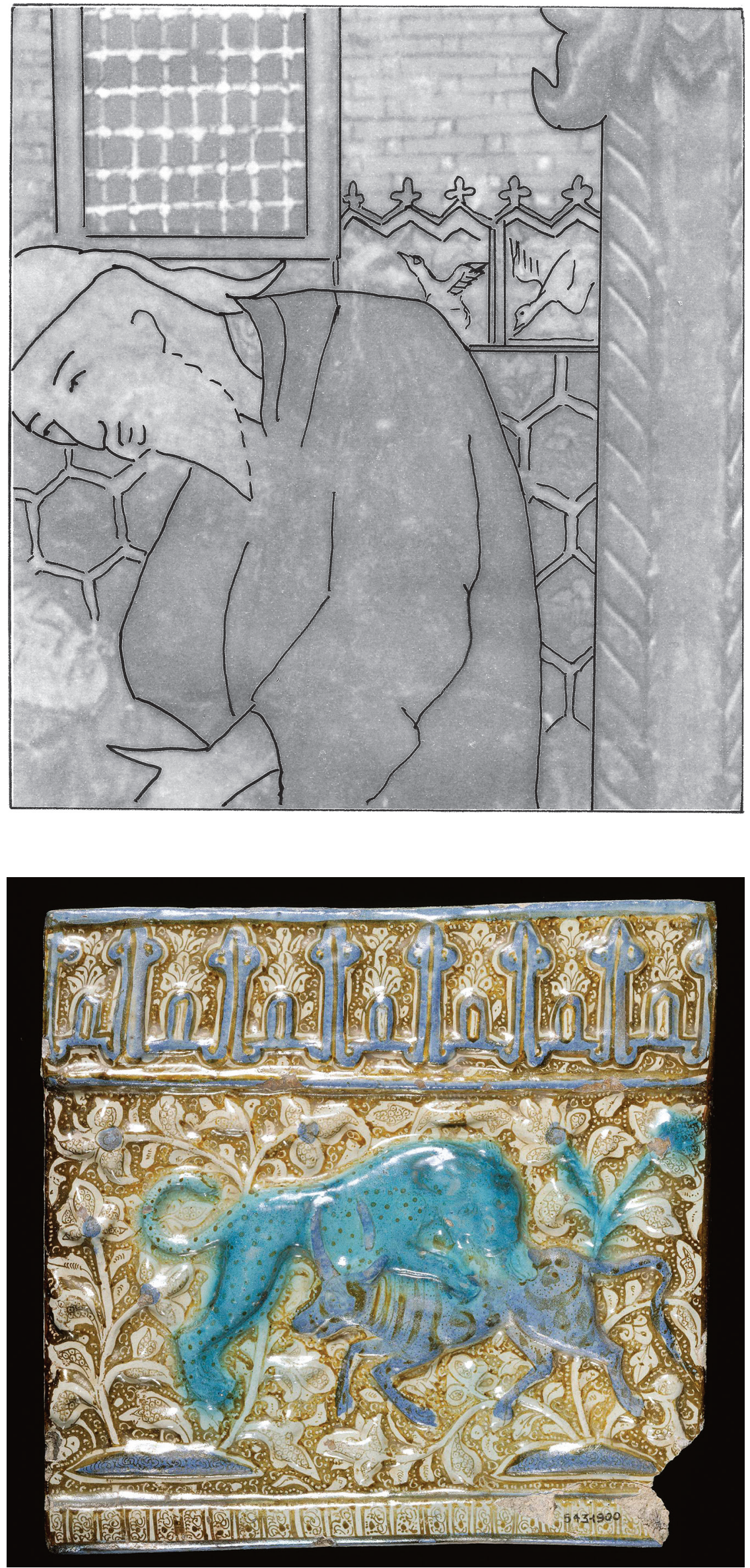

FIGURE 25

Faridun in the palace of Iraj, detail of tiled dado. Redrawn from Arthur M. Sackler Gallery, S.1986.100

(C) YVES PORTER
FIGURE 26

Luster tile with lion attacking a bull. Victoria and Albert Museum, no. 543-1900

(C) VICTORIA AND ALBERT MUSEUM, LONDON 


\subsection{Position of the "First Frieze" at Takht-i Sulaiman}

Since each tile of the First Frieze measures about $0.30 \mathrm{~m}$ long, sixty tiles are approximately $18 \mathrm{~m}$ long. The precise location of these tiles inside the palace is unknown; as already suggested, "they may have been installed above a dado consisting of lusterpainted star and cross tiles" (Masuya 1997: 491; Fig. 27). If, as mentioned above, the Northern Octagonal Room must probably be rejected, Naumann proposes a reconstruction of the Southern Octagon where a frieze of square tiles can also be seen (Naumann, 1977: Abb. 76). Evidently, this cannot exclude other hypothetical locations. A painting

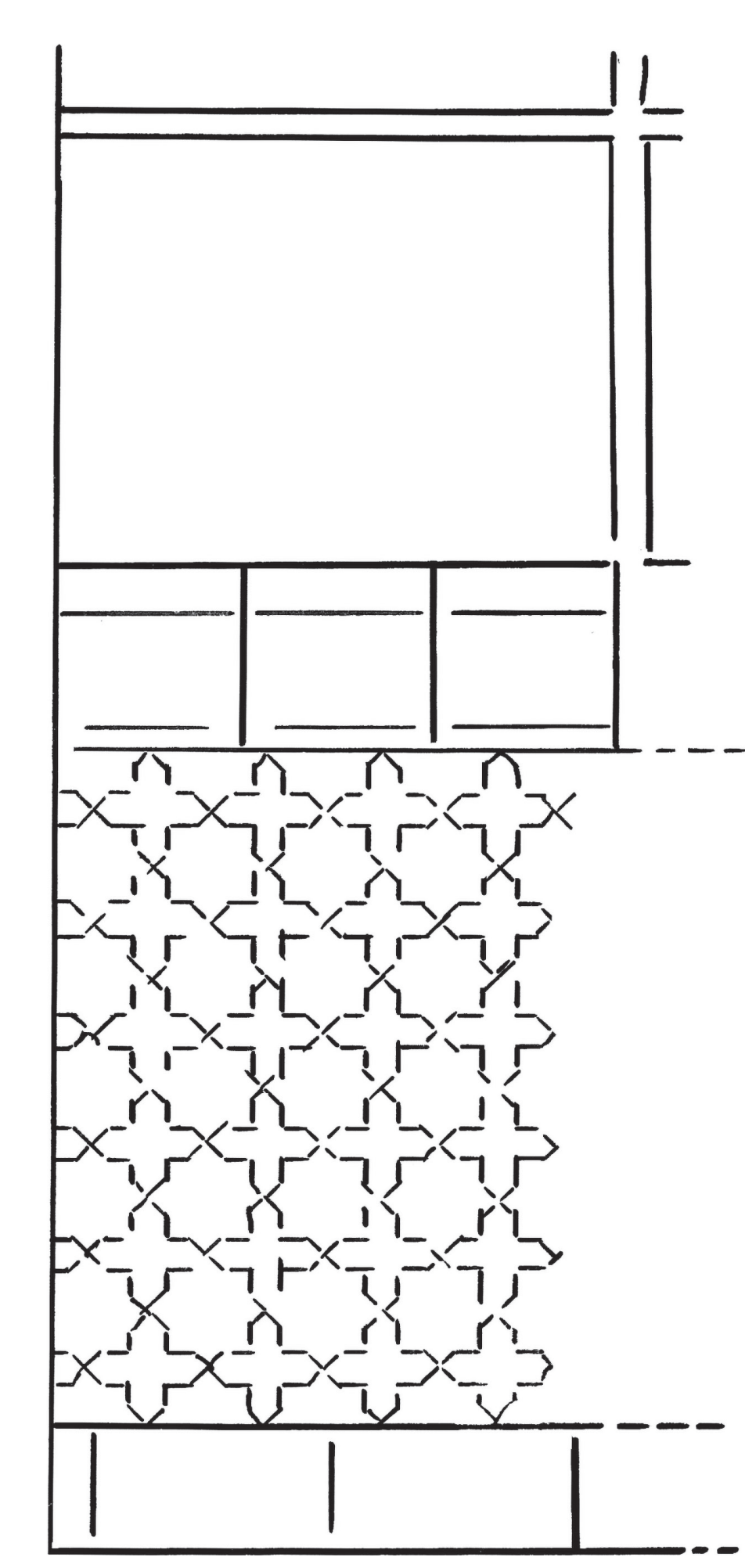

FIGURE 27

Tiled dado, redrawn after Naumann (1977: Abb. 66) (C) YVES PORTER 
from a dispersed manuscript shows Keykhosrow Enthroned; behind the throne is a tiled dado surmounted by a calligraphic frieze in which the starting verses of the Shah-nama can be read. Mélikian-Chirvani published this painting to suggest that this type of epigraphic frieze was used on the walls of throne rooms (Mélikian-Chirvani, 1996: Figure 64). ${ }^{63}$ If one considers that these tiles crowned the dado surrounding the great western iwan (the rectangular hall described by Wilber, with a perimeter of circa $70 \mathrm{~m}$; Wilber, 1955: Cat. N. 15; plan, Figure 8), this would suggest that only about 25 percent of the total frieze is known. Consequently, even if this figure can easily be doubled (knowing that each hemistich needs its pair), it can be inferred that many tiles remain to be discovered.

\subsection{Eghvard's Tiles and Their Numbering}

The removal of Eghvard Church's tiles during the cleaning and restoration of the building also provided the occasion for studying their backs. Several of them had inscriptions, rapidly written with a brownish slip on the unglazed back before the last firing (i.e., contemporaneous with their making), figuring spelled-out numbers (Gyuzalyan, 1984: 158, ill. 2a-12a). Unfortunately, some inscriptions were hard to read.

The quotes are listed below, following the order of the text (numbers between square brackets are those written on the backs of the tiles; Figs. 28-34):

1. Gerâzande âhu be-râgh andarun / The proudly walking gazelle, inside the meadow (Cat. 1.15) [29?] $]^{64}$ (Gyuzalyan, 1984: ill. 11-11a).

2. Ze changâl-e yuzân hame dasht gharm / The whole plain is made angry by the claws of the cheetahs (Cat. 1.22) [50?] ${ }^{65}$ (Gyuzalyan, 1984: ill. 12-12a).

3. Cho bidâr gardi jahân-râ bebin / When you wake up, look at the world (Cat. 1.27) [14] (Gyuzalyan, 1984: ill. 10-10a).

4. Konun khword bâyad mey-e khosh gavâr / Now [we] must drink this exquisite wine (Cat. 1.29 (Gyuzalyan, 1984: ill. 8); see Fig. 5.

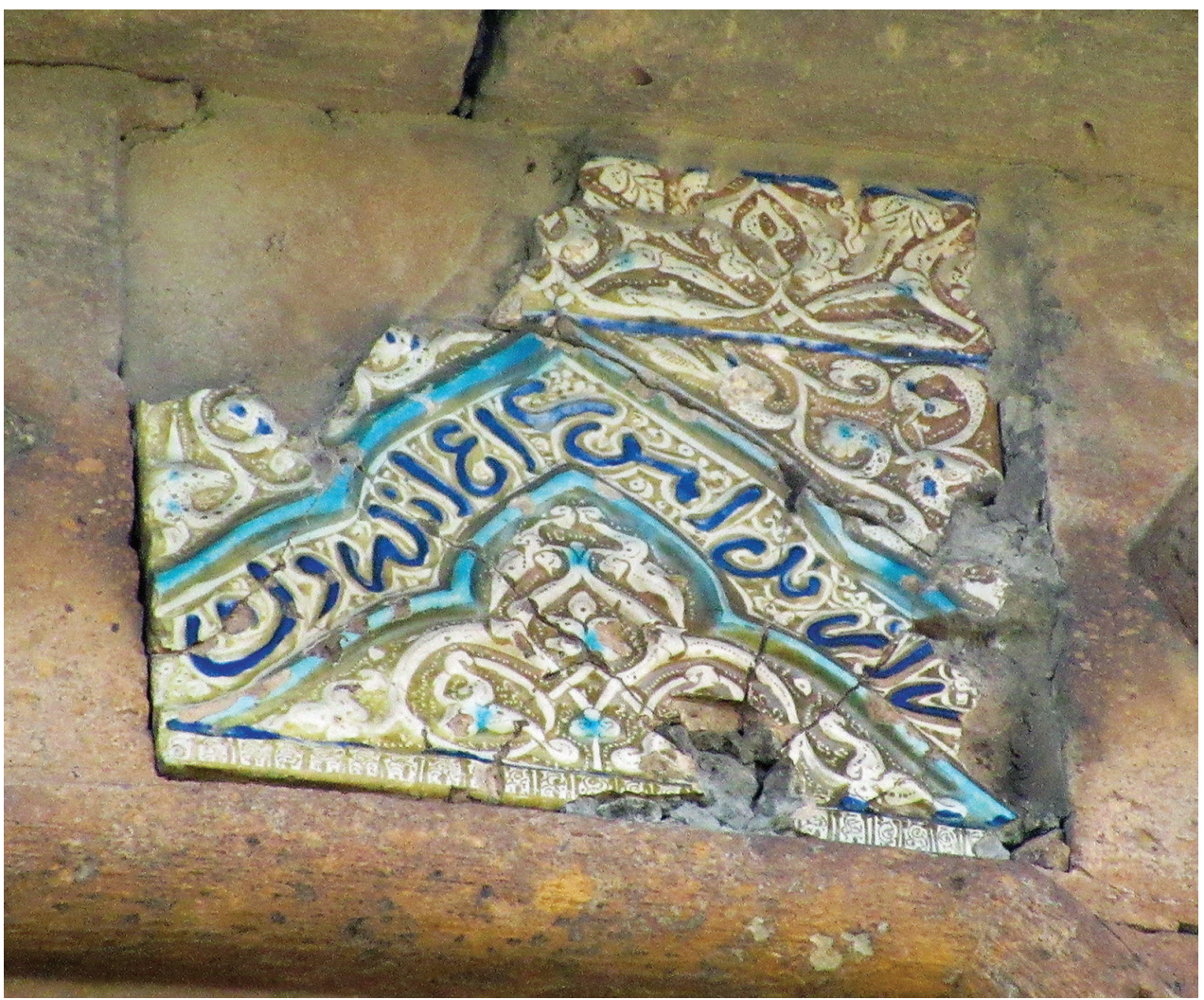

FIGURE 28

Eghvard, Tile 23; text: Gerâzande âhu be-râgh andarun (Cat. 1.15) (C) PHOTO P. DONABÉDIAN 
FIGURE 29

Eghvard, Tile 17; text: Ze changâl-e yuzân hame dasht gharm

(Cat. 1.22)

(C) PHOTO P. DONABÉDIAN
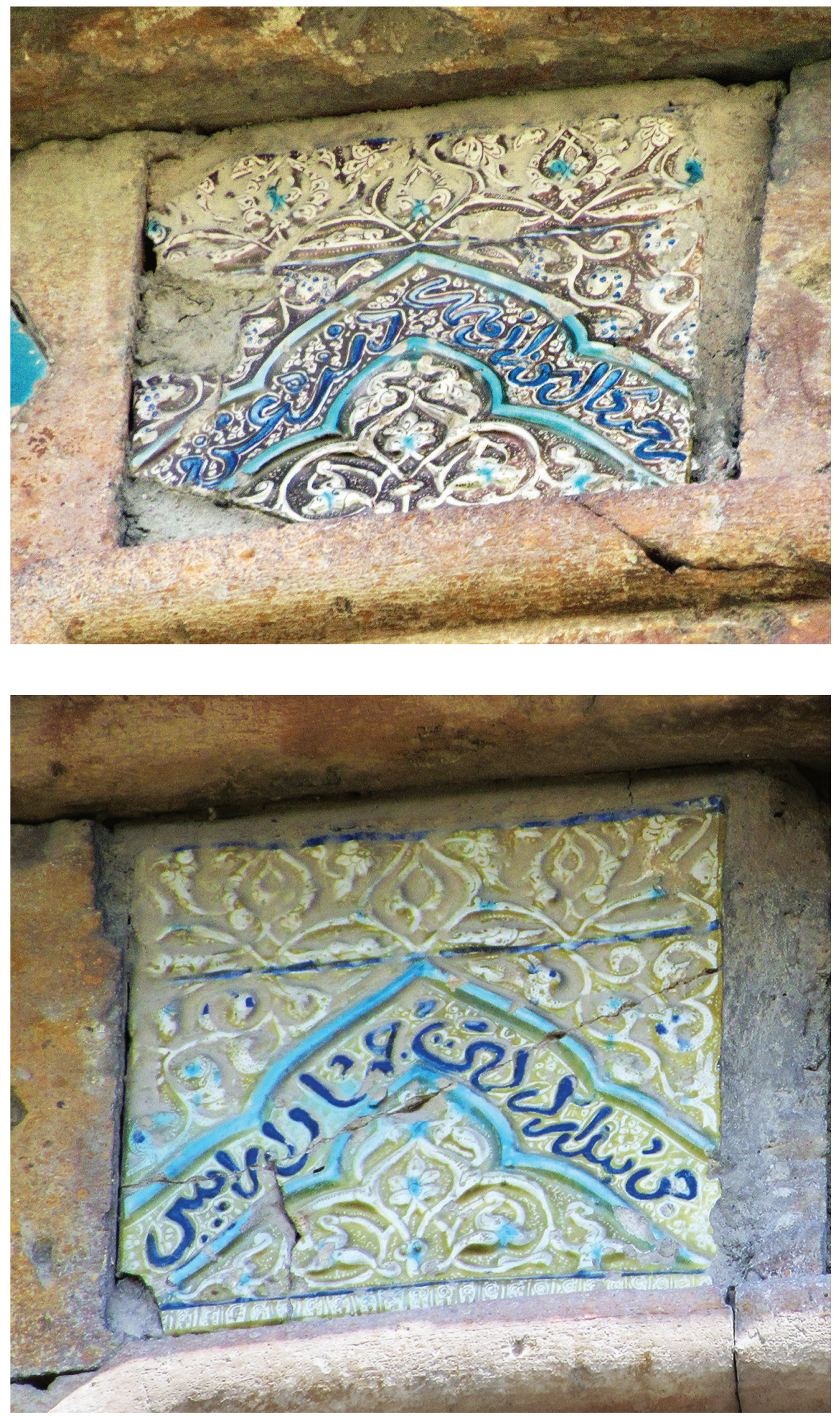

FIGURE 30
Eghvard, Tile 49; text: Cho bidâr gardi jahân-râ bebin (Cat. 1.27) (C) PHOTO P. DONABÉDIAN 

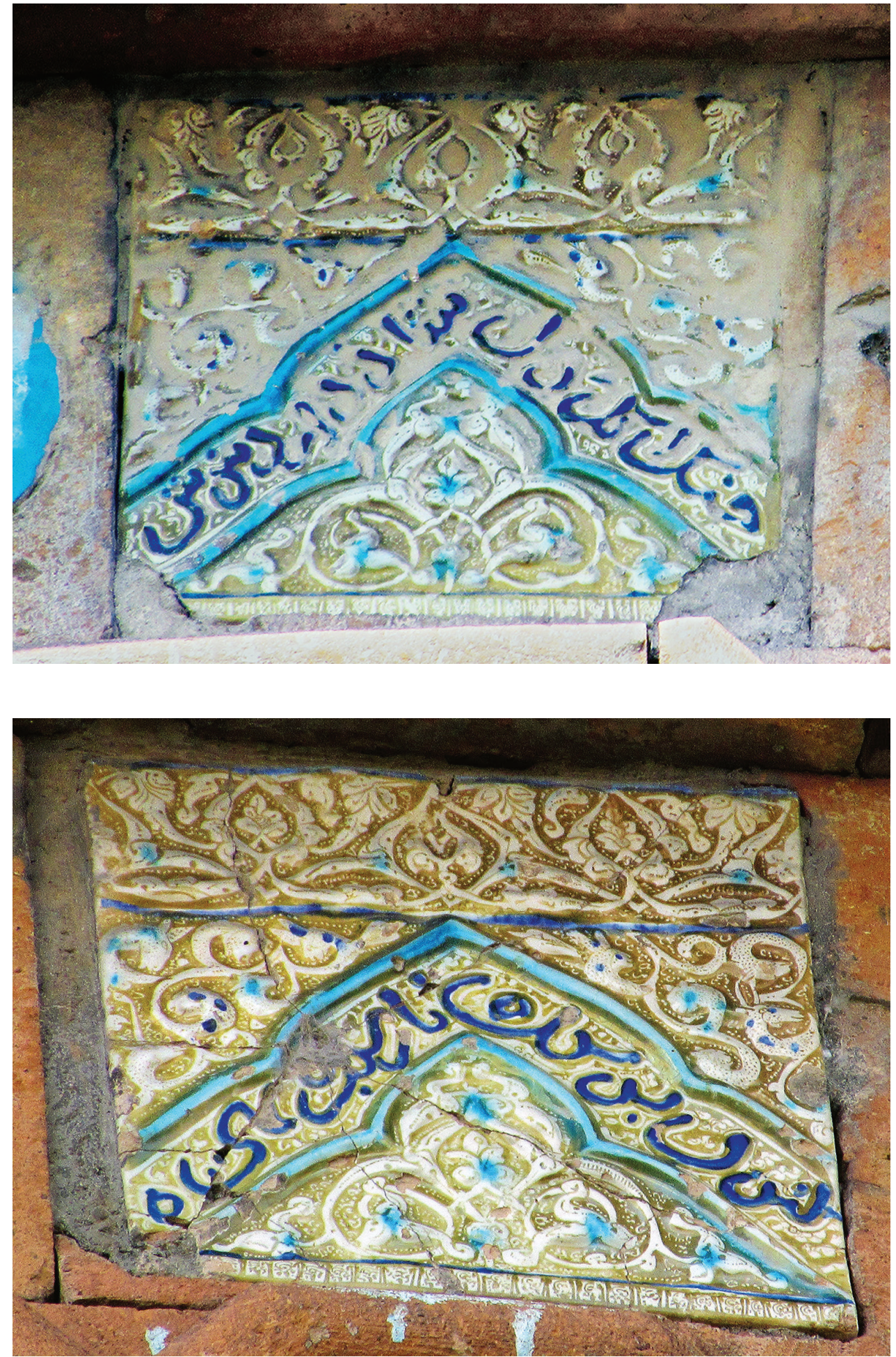

FIGURE 31

Eghvard, Tile 53; text: Khonok ânke delshâd dârad benush (Cat. 1.31) (C) PHOTO P. DONABÉDIAN
FIGURE 32

Eghvard, Tile 7; text: Konun bar gol-o nâr-o sib-o behi (Cat. 1.37) (C) PHOTO P. DONABÉDIAN 
FIGURE 33

Eghvard, Tile 43; text: Cho bini rokh-e sib-e bijâde rang (Cat. 1.38) (C) PHOTO P. DONABÉDIAN
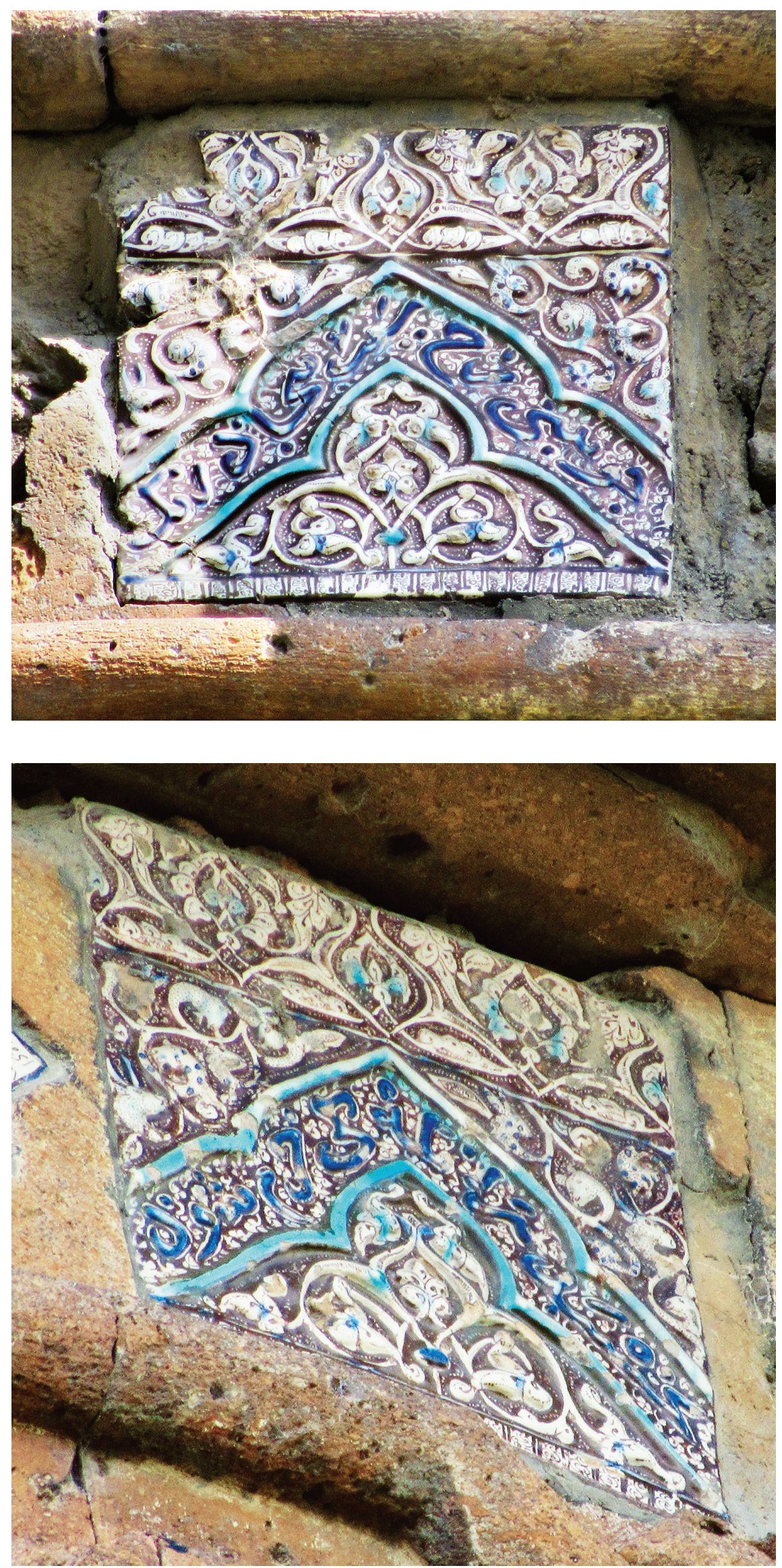

FIGURE 34

Eghvard, Tile 11; text: Bakhshad har ângah ki khorram shavad (Cat. 1.50)

(C) PHOTO P. DONABÉDIAN 
5. Khonok ânke delshâd dârad benush / Happy the one who drinks and feels contented (Cat. 1.31). ${ }^{66}$

6. Bakhshad har ângah ki khorram shavad / He will bestow on every rejoicing place.

7. Konun bar gol-o nâr-o sib-o behi / Now over roses, pomegranates, apples, and quinces (Cat. 1.37) [44] (Gyuzalyan, 1984: ill. 4-4a).

8. Cho bini rokh-e sib-e bijâde rang / When you will see the ruby-colored apple-face (Cat. 1.38) [46] (Gyuzalyan, 1984: ill. 5-5a).

9. Shavad âsemân hamcho posht-e palang / The sky will become like the skin of the panther (Cat. 1.40) [47 + لا ل $]^{67}$ (Gyuzalyan, 1984: ill. 6-6a); see Fig. 6.

From the examples above, some observations can be made:

- The sequence formed by tiles nos. 7-8-9 is numbered in Persian: 44-46-47; the absence of no. 45 is thus logical since a hemistich is missing.

- Tile no. 2 (numbered 50 if the reading is correct) was thus placed after the preceding ones; however, its quote belongs to a much earlier portion of the text.

- There is only a pair of tiles with matching hemistiches (8-9), thus figuring a complete distich. Number 7 is the first hemistich of the immediately preceding distich in the edited text.

The total number of known tiles does not allow understanding of their original arrangement; once the known hemistiches are placed in text order, they represent scattered quotations taken from diverse sequences in the Shah-nama. However, a hint is given again by Eghvard's tiles; numbered items suggest that the distiches, which were placed side by side, could belong to different, sometimes extremely distant, parts of Firdausi's epic. It appears thus that the whole frieze did not propose a continuous story, but only some excerpts, in the manner of a poetic anthology. Moreover, the hemistiches on some tiles display variations on Firdausi's text that are not found in current text editions.

Inscriptions on the backs of tiles can be seen on examples belonging to other series; thus, Gyuzalyan stated that the number 29 (bist-no) is written on the back of the tile with a linear inscription in Eghvard Church (Gyuzalyan, 1984: 157, ill. 2a.; see also Donabédian and Porter, 2017: 854, Catalogue, $\mathrm{n}^{\circ}{ }_{1}$ and Figure 32 ). The tile Richard Burton brought back from Tanzania, now in the British Museum, also has a number on its back (Mélikian-Chirvani, 1996: Figure 66). Mélikian-Chirvani already suggested that these figures indicate the order of tiles, or their total number. Traces of inscriptions can also be deciphered on the backs of two tiles from San Francisco's Asian Museum. ${ }^{68}$

Unfortunately, examples of tiles with numbers written on their backs are relatively rare; the backs may have been scratched after their removal from the walls to eliminate plaster remains or after restoration (since many tiles were probably broken during removal). Most of the tiles now show traces of relatively brutal abrasions and refilling.

\subsection{Context and Meaning}

The question of the "meaning" of these inscribed tiles is open to speculation, as could be the "intentions" behind their making. Undoubtedly, and despite their possible location on the walls of a "throne" or audience hall, the suitability of their location is less obvious than in the Ghazni or Alhambra palaces. If one followed Mélikian-Chirvani's viewpoint, the signification of the Shah-nama quotes must be considered as conveying a strong "ideological" message. Likewise, Melville (2018) emphasizes the echo of the narrated "stories" chosen for the tiles studied in her contribution.

The "bottom-up" method envisioned here commands basing the arguments on the existing material only. Thus, without entering an "ideological" reading, if one considers the totality of the known tiles (encompassing all series), the "anthological" aspect of the quotes appears clear. 


\section{Tiles}

TABLE 2

Text-wise repartition (\%) of 61 tiles according to Shah-nama volumes (C) YVES PORTER

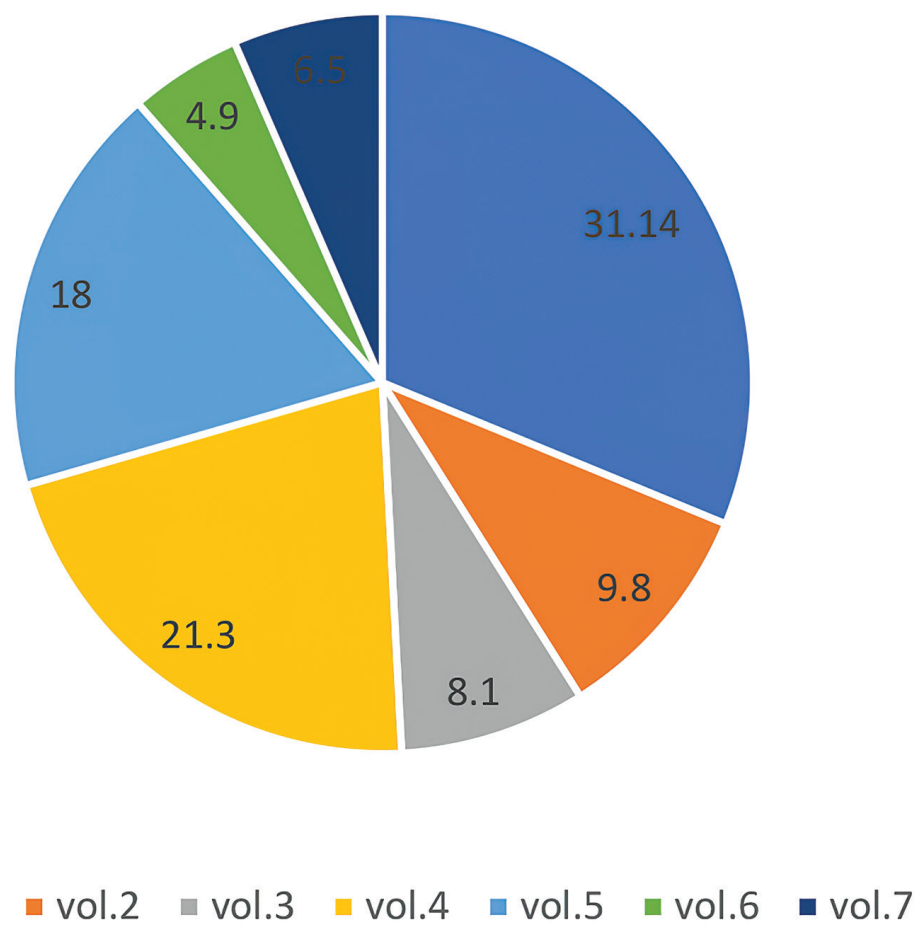

Based on current knowledge, verses from the Shah-nama are taken from all parts of the text (Table 2). ${ }^{69}$ However, the quotations copied on tiles are generally more anacreontic than heroic or narrative. The names of kings and heroes or historic figures are extremely rare on the surviving tiles. ${ }^{70}$ Conversely, descriptions of nature or allusions to wine and music are much more abundant. Moreover, due to their anthological aspect, narrative unity is impossible. Thus, the quoted verses can be placed as random pairs. The impossibility of having a whole story quoted on the palace walls suggests that the chosen verses "spoke for themselves." Thus, like the exordia (tashbib) of a qasida praising a prince, the festive description of nature in spring or the beauties of the beloved function as a frame for the glory of the palace's resident. ${ }^{71}$ Hence, the valorization of the palace as a beauty of the kingdom might be considered rather than a direct panegyric of the monarchy. ${ }^{72}$

It is difficult to measure whether the choice of the verses can be deduced from the remaining tiles. However, some observations can be made, especially about series of tiles containing consecutive verses.

The largest series of consecutive verses on tiles is represented by nine items (Cat. 1.28-1.34 of Frieze I, to which tiles 2.2 and 5.2 can be added); they correspond to verses 2391-6 of volume IV, introducing the story of Rostam and Esfandyar in an elegiac and Bacchic mode. The sequence starts with Konun ("now"):

Now [we] must drink this exquisite wine.

And ends with,

May the rose thrive from his [the nightingale's] complaint. ${ }^{73}$ 
Notably, this excerpt is known as a favorite by Juvaini; as highlighted by MélikianChirvani, he quotes it twice in his History of the World Conqueror, both times evoking episodes during spring by the Kerülen river (Mélikian-Chirvani, 1991: 61). ${ }^{74}$

Similarly, tiles 1.37-1.42 from Frieze I correspond to verses 1288-91 of volume $\mathrm{V}$ and originate from a story recounting Bahram Gur's hunts; the verses are preceded by a passage in the first person (lines 1281-7), in which the king is speaking about his own deeds. Curiously, the text on tile 1.38 (text line 1289a) uses the second person (cho bini, "When you'll see") instead of first (cho binam, "When I'll see") in the edited text, addressing a more general audience. As per the preceding quote, it also starts with "Now":

Now, over roses, pomegranates, apples, and quinces,

there must be no bottom to the wine of the golden cup.

Following the somewhat "impersonal" description of wine, beauties, and nature found in the verses copied on the above-mentioned tiles, the discourse of Bahram Gur in the "original" version reverts to the first person after verse 1292.

These examples indicate that the "intention" is less to provide an exact reference, deeply rooted in Firdausi's epic, of the Iranian kingship and heroes, than to achieve an evocation of beauty and immediate pleasure through a text-wise distanced allusion. This "distance" would also explain the variations in the verses found on some tiles, absent from current editions of the Shah-nama.

\section{$5 \quad$ Conclusion}

The domain of palace decoration and, more generally, that of "secular" Ilkhanid architecture remains largely unexplored. Thus, its tiled revetments only represent a facet of a much wider subject. However, through the limited number of cases examined here, and starting from a single pattern of a tile made using the coveted luster technique, one can now perceive not one but multiple examples of vanished princely residences. Concluding that luster tile decoration was not limited to Takht-i Sulaiman might have previously appeared obvious or probable. The bases for studying further examples are now established. Many topics require further exploration.

The royal abodes, either urban/perennial or seasonal/ephemeral, represented the image and actual presence of the rulers. As such, they formed an important dispositive in the territorial network of the Ilkhans. The occurrence of verses from the Shah-nama on their walls played a role in this royal imagery. This practice was the continuation of a long tradition, as can be conjectured by the words of another Ghaznavid poet, Farrokhi Sistani (d. 1038), in his description of a royal palace:

In it are inscribed the praises of kings

Based on the sayings of these and those. ${ }^{75}$

In the Ilkhanid context, the quotes from the Shah-nama in palatial decoration are often considered a structural part of a temporal and transcendent paradigm (i.e., the uninterrupted, "eternal" Iranian monarchy). Conversely, the above observations indicate a spatial, "immediate" occupation devoted to the hic et nunc (konun, in Persian) enjoyment, with few allusions to any religion. The Ilkhanid palaces emerge as landmarks of the dynastic prosperity closely following the economic rhythms. They embody the metonymy of this prosperity, and the verses quoted on their tiles are, then, their hyperbolic rendition. 
Moreover, the royal patronage of luster-tiled decors appears limited to the palaces. None of the great ensembles adorning religious buildings can be credited to the Ilkhans. Thus, monumental decors commissioned for shrines and mosques only mention individuals originating from the Iranian elites (Porter, 2018: 445-8). As previously suggested, whether these grandees commissioned luster tiles for their residences remains an open question.

Another noticeable feature concerns the timespan of these luster tile friezes and, more importantly, the presence of an epigraphic program in Iranian palaces. As previously suggested, the existence of luster tile friezes quoting the Shah-nama may have been longer than the period during which Takht-i Sulaiman was built (c. 1270-5). However, after the death of Abu Sa'id (1335) and the subsequent decline of the Ilkhanids, the production of luster tiles decreased and was abruptly interrupted after 1339 (Watson, 1985: 196-7). ${ }^{76}$ Barely any remains of palaces exist for the period between Takht-i Sulaiman and the earliest surviving Safavid residences (mid-sixteenth century). However, concerning the latter, the almost total absence of any monumental epigraphy is observed. Instead, the lack of written quotes is, to some extent, compensated by the presence of large mural paintings.

The cartography of Ilkhanid royal residences still requires completion, especially by crossing textual sources with archaeological surveys. The source survey proposed here is not exhaustive; moreover, recent archaeological research in Iran and neighboring areas remains insufficiently available, especially concerning luster tiles. ${ }^{77}$ Although some potential locations of Ilkhanid palaces or summer residences have been proposed, the possibility that these places were decorated with luster tiles would need confirmation. Future archaeological surveys will yield new evidence of palatial architecture and tile fragments; the unexpected find of an isolated fragment probably reused at Zulfabad indicates this direction.

The anthological aspect of the Shah-nama tiles renders the reconstitution of a complete frieze almost impossible. However, other study directions remain. In the philological and semiotic domains, how the "morceaux choisis" were collected and arranged requires development. Beyond Mélikian-Chirvani's seminal work on the meaning of Firdausi's quotations in palatial architecture, the study of the textual variants absent from current Shah-nama editions, for instance, would need additional research. ${ }^{78}$ This aspect should also be connected with the ceramic workshop "system of production" and more specifically with how the potters collected and stocked their poetic material to be used on vessels and tiles.

The Catalogue of tiles proposed hereafter, although already more expanded than previous attempts, must be completed. Unknown tiles and fragments might lie unnoticed in public or private collections or still be underground. Thus, while these friezes will remain incomplete due to irremediable losses, it is hoped that knowledge of their context will progress.

\section{Catalogue of Tiles}

References:

- Tiles are arranged:

- by series of decor (Friezes I-VIII);

- according to Shah-nama's sequence (volume, page, line, hemistich a/b).

- Text references follow J. Mohl's “jibi" edition (Tehran, 1345/1966); all translations are my own.

- Order number is followed by present location or sale catalogue; history, condition, and dimensions are added when known. 
Bibliography is limited to ASMC and Masuya unless tiles are published only elsewhere.

- Tiles appearing in ASMC publications (ASMC 1985, 1991, 1996) are not arranged "catalogue-wise" by this author; order numbers between square brackets are thus my own.

- Masuya refers to Tomoko Masuya's thesis, Chart XVIII: Shahnama quotations on 6-1-G Tiles (pp. 716-20).

- Her numbers 1-25 correspond to tiles with identified inscriptions (to which ISL (SM B-PK) I. 4/67,35 must be added; see hereafter Cat. 1.13).

- Numbers 26-7 are inscriptions with several possible identifications.

- Numbers 28-31 are unidentified inscriptions with AS MC's suggested identifications.

- Numbers $32-5$ are unidentified inscriptions.

- Numbers 36-8 are repaired and 39-40 are fragments (to which three unnumbered items are added).

\section{Frieze I (Fifty-Four Tiles and Nine Fragments, Nos. 1.1-1.63)}

\section{Volume I: Sixteen Tiles}

Na bini ma-ranjān do binande rā / If you do not see, do not torment both your eyes.

(Mohl jibi I, p. 3, l. 5b)

1.1 Sotheby's, Islamic Works of Art, London, 16-17 April 1985, $\mathrm{n}^{\circ} 286$.

Incomplete; upper band missing.

$22.5 \times 29.8 \mathrm{~cm}$

- ASMC $1991\left[\mathrm{n}^{\circ} 1\right]$, p. 91, note 118, and Figure 11.

- Masuya 1

1.2 A second, complete tile, with same hemistich; present location unknown (found on Pinterest, without any references)

- Unpublished (?)

Dar andishe-ye sakht ki ganjad u / Who could enclose Him in his harsh mind?

(Mohl jibi I, p. 3, 1. 1ob)

1.3 Sotheby's, Islamic Works of Art, London 15 October 1986, $\mathrm{n}^{\circ} 100$.

c. $30 \mathrm{~cm}$ by side

According to ASMC, this tile was previously in the collection of M. Riahi. Reproduced in the catalogue Le Mille e una notte, Faenza, 1990, no. 64, p. 98.

- ASMC $1991\left[\mathrm{n}^{\circ} 2\right]$, p. 91, note 120, and Figure 12

- Masuya 2

Kherad-e tire-o mard-e rowshan ravān / The dark spirit and the man of enlightened soul. (Mohl jibi I, p. 4, 1. 21a)

1.4 Shangri La, DDF 48.346.1; Sotheby's Parke Bernet Galleries, 16 February 1943. $29.8 \times 29.8 \mathrm{~cm}$

- Unpublished

Kazinat resad nik o bad bigomān / Without doubt, from this, good and bad will come for you.

(Mohl jibi I, p. 4, 1. 28b)

1.5 Malaysia Museum, Kuala Lumpur, IAMM, 2003.10.17.

$29.8 \times 29.8 \mathrm{~cm}$

- Heba Nayel Barakat, The Arabesque: An Introduction, Kuala Lumpur, IAMM, 2018, cat. no. 34, Figure 164 .

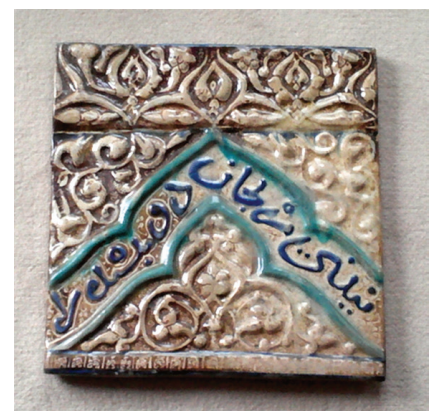

THUMBNAIL 1

Cat. 1.2. Present location unknown (C) PINTEREST 


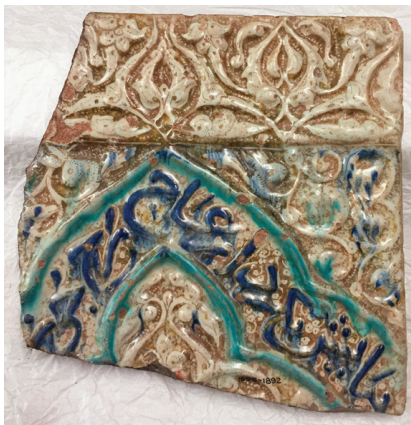

THUMBNAIL 2

Cat. 1.11. Victoria and Albert Museum no. 1696-1892 (C) VICTORIA AND ALBERT MUSEUM, LONDON
Ze har dāneshi chun sokhan beshnuy / When you will listen to the words of each wisdom? (Mohl jibi I, p. 5, 1. 34a)

1.6 Shangri La, DDF 48.346.2; Sotheby's Parke Bernet Galleries, 16 February 1943. $29.8 \times 29.8 \mathrm{~cm}$

- Unpublished

Ze garmish pas khoshki āmad padid / Its heat, then its dryness will become patent.

(Mohl jibi I, p. 5, 1. 4ob)

1.7 Private collection, Japan.

- Masuya 3 (Pl. 202-a)

Gavāhi deham kin sokhanhā ze ust / I attest that these words are his.

(Mohl jibi I, p. 8, 1. 102a)

1.8 Olympia Auctions, Arthur Millner, Islamic, Indian, Himalayan and South East Asian Art, Thursday 6 November 2014, Lot 342. www.auction.fr/_fr/lot/a-kashan-lustre -pottery-square-tile-a-kashan-lustre-pottery-square-tile-decorated-16o47184. $30 \mathrm{~cm} \times 30 \mathrm{~cm}$

- Unpublished

Ki khodh parvarāniva khodh beshekari / You tear down [those] that you have nourished. (Mohl jibi I, p.57, l. 538b)

1.9 Laurin, Guilloux, Buffetaud, Tailleur, Art d'Orient, Paris, Drouot, 14 mars 1983, no. 87 .

$30 \times 30 \mathrm{~cm}$

- ASMC $1985\left[\mathrm{n}^{\circ} 1\right]$, p. 274, note 41 , and Figure 4.

- Masuya 5

[Ke ruya]sh ze khorshid nikutar [ast] / Whose face is more beautiful than the sun. (Mohl jibi I, p. 123, 1. 384b)

1.10 Uto Auktionen, Islamic Works of Art: The Kitabgi Collection and Others, Zurich, 4 November 1976, no. 1156 , ill. p. 42. $30 \mathrm{~cm}$ by side

- ASMC $1985\left[\mathrm{n}^{\circ} 2\right]$, pp. 274-5, note 42, and Figure 5 .

- Masuya 6

[Ze sar tā] pāyash be-kerdār-e ‘ājj / be-rokh [behesht va bebālā cho sāj] / From head to toe resembling ivory / the face like heaven and the loftiness of the teak-tree.

(Mohl jibi I, p. 123, l. $385 \mathrm{a}-\mathrm{b})$

1.11 V\&A 1696-1892. http://collections.vam.ac.uk/item/O342412/fragment-unknown/. $25 \max \times 26.9 \times 2.2 \mathrm{~cm}$ Tiles from this series with more than one hemistich are exceedingly rare.

- ASMC 1985 [n०3]; ASMC 1991 [n8], p. 112, note 165, and Figure 23.

- Masuya 7

[Yeki izad] i bar sar az moshk tāj / A divine creature crowned with musk. (Mohl jibi I p. 128, 1. 525b)

1.12 Vente Collection de M. Porcher-Labreuil, Nice 19-21 March 1934, p. 25 no. 142, and Pl. VII; Paris Drouot, 1986 (Picard/Arcache). Incomplete, refilling.

- ASMC 1991 [n $\left.{ }^{\circ} 13\right]$, p. 147, note 244, and Figure 29.

- Masuya 8 
[See Fig. 1]

[Foru mānd Sindokh] t az in goft [o guy / pasand ämadesh Zāl rā joft uy]? / Sindokht was perplexed by these words / She agreed in matching Zal with her.

Text reconstructed according to ASMC. (Mohl jibi I, p. 144, l. 904a)

1.13 Berlin, Museum Islamischer Kunst, Nr. I. 4/67.35.2.

- Fragment found at Takht-i Sulaiman; the height dimension given by the museum online data $(36.3 \mathrm{~cm})$ cannot be correct; width: $18.4 \mathrm{~cm}$; thickness: $3.6 \mathrm{~cm}$.

- Naumann (1977), pl. 6b no. 122.

- ASMC $1985\left[n^{\circ} 4\right]$ p. 276; ASMC 1991 [nº 9 ], p. 113, Figure 24.

- Masuya, unnumbered (between 8 and 9)

[Koj] $\bar{a}$ bāre-ye to konad mu-ye tar / On the place where its hair will be wet.

(Mohl jibi I, p. 165, l. 1410a)

1.14 Uto Auktionen, Islamic Works of Art, Zurich, 4 November 1976, p. 42, no. 1158. Broken, parts missing.

- ASMC 1985 [n ${ }^{\circ} 5$ ] pp. 277-8 and Figure 6; ASMC 1991 [nº ${ }^{\circ}$ ], p. 110, and Figure 21.

- Masuya 28

[See Fig. 28]

Gerāzande āhu berāq andarun / The proudly walking gazelle, inside the meadow

(Mohl jibi I, p. 245, l.32b)

1.15 Eghvard Church, Cat. 23.

Incomplete; back with number 29 or 69

- Gyuzalyan, ill. 11

- Donabédian and Porter, Cat. 23, Figure 48.

Golābist gu'i be-juyesh ravān / You would say that rosewater flows in the rivulet.

(Mohl jibi I, p. 245, l. 34a)

1.16 Parke-Bernet $1977 \mathrm{n}^{\circ} 35$.

- ASMC $1985 \mathrm{n}^{\circ} 6$ (Figure 16)

- Masuya 9

\section{Volume II: Four Tiles}

Chenin goft ba nämdārān[-ejang] / So he spoke to the reputed lords of war.

(Mohl jibi II, p.28, l. 587a)

1.17 Museo Arqueológico Nacional, Madrid, no. 73/58/PI/56; Ex Colección Santa-Olalla.

H. $21.7 \mathrm{~cm}$; incomplete.

- Catálogo de la Exposición de Antigüedades Persas, Madrid 1971, no. 638 and p. 104.

- ASMC 1985 [ $\left.{ }^{\circ} 18\right]$; ASMC 1991 [n $\left.{ }^{\circ} 12\right]$ p. 120 and Figure 28.

- Masuya 26 (several possible identifications)

Suy-e band kardanesh be-shetäftand / They made haste to tie him/it.

(Mohl jibi II, p. 38, 1. 37b)

1.18 Daussy-Ricqlès, Drouot 22 juin 1992, no. 18 (former Abrami collection).

- Masuya 10

[?] che goft ān honar-juy-e bā-hush/ ... so spoke this clever and wise.

(Variant of Mohl jibi II, p. 199, l. 2362a)

1.19 London private collection.

$30.5 \mathrm{~cm} \times 30.5^{-31.2 \mathrm{~cm}}$

- ASMC 1991 [ $\mathrm{n}^{\circ}$ 10], p. 113 and Figure 25.

- Masuya 29 (unidentified, with ASMC's suggestion) 
Ke u dād bar nik-o bad dastgāh / He has given the rule on good and bad.

(Mohl jibi II, p. 333, l. 125ob)

1.20 Gemeente Museum, Den Hague, no. 0558623; Ex J.W. N. Van Echterbergh collection

(OKI-343).

$30.2 \mathrm{~cm} \times 29.9-30.5 \mathrm{~cm}$

www.kunstmuseum.nl/en/collection/tegel-2?origin=gm

- ASMC $1991\left[\mathrm{n}^{\circ} 5\right]$, p. 98 and Figure 17.

- Masuya 27 (several possible identifications)

Volume III: Three Tiles

Beneh gush-o del-rā be-ā $v \bar{a} y$-e chang / Listen from hear and heart to the song of the harp. (Adapted from Mohl jibi III, p. 149, l. 49b)

1.21 Firenze, Museo Bargello. From collection of Louis Carrand, before 1895 . www.controradio.it/islam-e-firenze-arte-e-collezionismo-dai-medici-al-novecento/

- ASMC $1985\left[\mathrm{n}^{\circ} 7\right]$ (Figure 14); ASMC 1991 p. 111.

- Masuya 30 (unidentified, with ASMC's suggestion)

[See Fig. 29]

Ze changāl-e yuzān hame dasht gharm / The whole plain is made angry by the claws of the cheetahs.

(Mohl jibi III, p. 151, l. 113a)

1.22 Eghvard Church, Cat. 17 .

The back has $50($ ?) inscribed.

- Gyuzalyan, ill. 12

- Donabédian and Porter, Figure 47.

Va z'än bar sarat niz peyghäre nist / One could not blame you because of this.

(Variant of Mohl jibi III, p. 292, l. 2035b)

1.23 Artcurial- Briest-Poulain-F.Tajan. Arts d'Orient et de l'Islam Quatre Collections Privées. 12 Mai 2014, lot 275; previously Kevorkian, Paris; collection X. Guérand-Hermès. www.artcurial.com/sites/default/files/pdf-catalog/2017-o9/2365.pdf

$29.5 \times 29.5 \mathrm{~cm}$

Restored, completed.

- ASMC $1991 \mathrm{n}^{\circ} 7$ Figure 22.

- Masuya 11

Volume Iv: Eleven Tiles

[Hamān mive-ash] chun cherāgh-e behesht / [This very fruit,] like a beacon from paradise.

(Mohl jibi IV, p. 9o, l. 2061b)

$\mathbf{1 . 2 4}$ (Sotheby $1985 \mathrm{n}^{\circ} 146$ )

Incomplete.

- ASMC $1991\left[\mathrm{n}^{\circ} 11\right]$, Figure 26.

- Masuya 12

Fereydun-o Hushang-e Yazdānparast / Faridun and Hushang, worshippers of God.

(Mohl jibi Iv, p. like a beacon from paradise 118, 1. 2723a)

$\mathbf{1 . 2 5}$ (Parke-Bernet $1970 \mathrm{n}^{\circ}{ }_{109}$ )

- ASMC 1985 [n8] Figure 17; ASMC 1991 p. 115, Figure 18.

- Masuya 13 
Ze läle farib o ze [narges shakib] / The coquetry of the tulip and the [patience of the narcissus].

(Variant of Mohl jibi IV, p. 245, l. 1542a)

1.26. Victoria \& Albert Museum, 550-19oo http://collections.vam.ac.uk/item/O345626/ fragment-unknown/

$$
17 \times 28.9 \times 2.8 \mathrm{~cm}
$$

Incomplete; the back has traces of an inscription.

- ASMC 1996 (included in his frieze III), p. 13, Figure 5.

- Masuya 14? (she refers to "Parke Bernet 1970")

[See Fig. 30]

Cho bidār gardi jahān-rā bebin / When you will wake up, look at the world.

(Mohl jibi IV, 245, 1. 1545a)

1.27 Eghvard Church, Cat. 49 .

The back has chahärdah ("fourteen") inscribed.

- Gyuzalyan, ill. 10.

- Donabédian and Porter, Figure 50.

[See Fig. 2]

Konun khword bāyad mey-e khosh gavār / Now [we] must drink this exquisite wine.

(Mohl jibi IV, p. 281, l. 2391a)

1.28 British Museum 1878,1230.573.1; bequeathed by John Henderson, 1878. www.britishmuseum.org/collection/object/W_1878-1230-573-1

$29.7 \times 30.3 \mathrm{~cm}$

- ASMC $1985\left[\mathrm{n}^{\circ} 10\right]$, Figure 8.

- Masuya 15

[See Fig. 5]

Same hemistich.

1.29 Eghvard Church, Cat. 13 . Incomplete.

- Gyuzalyan Figures 8-9

- Donabédian and Porter, Figure 46.

Hava por khorush-o zamin por ze jush / The air is full of clamors and the earth is shuddering.

(Mohl jibi IV, p. 281, 1. 2392a)

1.3o Kuwait, private collection; sold at Drouot, C. Boisgirard amd A. de Heckeren, Arts d'Orient. Collection du Dr. C. Lacoux et à divers, Paris, Drouot, 21 mai 1980, ${ }^{\circ} 49$.

- ASMC $1985\left[\mathrm{n}^{\circ} 11\right]$, Figure 9.

- Masuya 16

[See Fig. 31]

Khonok ānke delshād dārad benush / Happy the one who drinks and feels contented.

(Mohl jibi IV, p. 281, l. 2392b)

1.31 Eghvard Church, Cat. 53 .

- Not in Gyuzalyan.

- Donabédian and Porter, Figure 53.

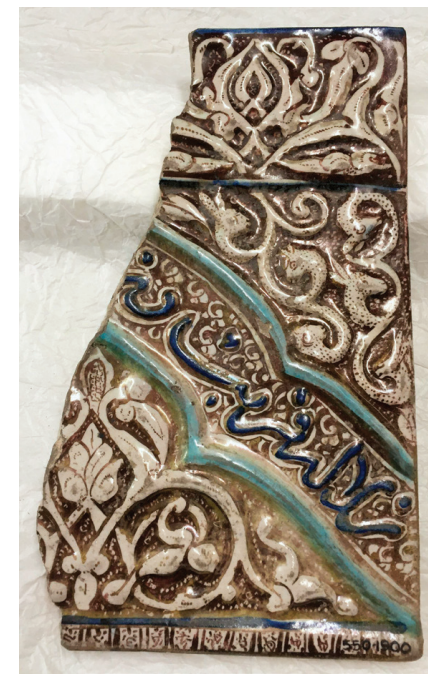

THUMBNAIL 3

Cat. 1.26. Victoria and Albert

Museum, 550-1900 (face)

(C) VICTORIA AND ALBERT

MUSEUM, LONDON

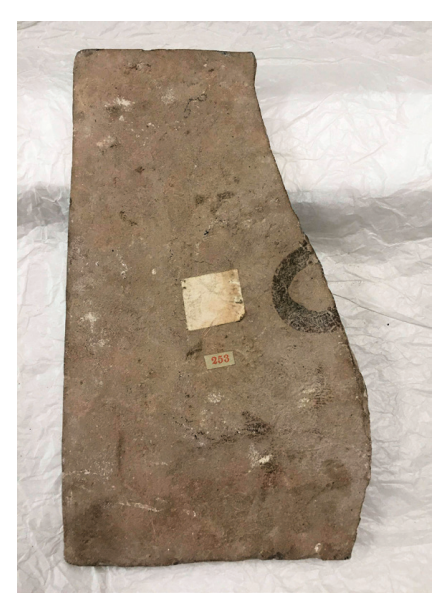

THUMBNAIL 4

Cat. 1.26. Victoria and Albert Museum, 550-1900 (back) (C) VICTORIA AND ALBERT MUSEUM, LONDON 


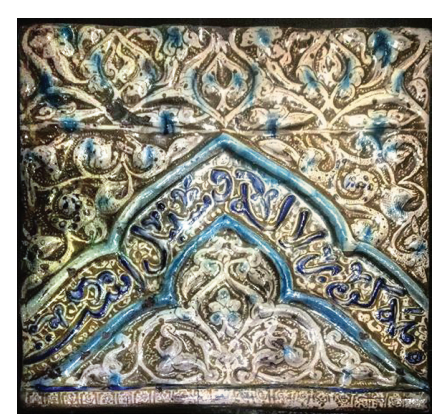

THUMBNAIL 5

Cat. 1.33. Reza Abbasi Museum, Tehran

(C) PHOTO ANAÏS LEONE
Hame kuh por läle-o sonbol-ast / The whole mountain is covered with tulips and hyacinths.

(Mohl jibi IV, p. 281, 1. 2395b)

1.32 Asian Art Museum, San Francisco, B6oP2146; The Avery Brundage Collection; previously O. Homberg's collection.

- Aimée Froom, Persian ceramics, 2008, nº33

- Masuya 17

Same hemistich.

1.33 Reza Abbasi Museum, Tehran.

(Unpublished) www.picuki.com/tag/kashantiles

Gol az nāle-ye u bebāladh hami / May the rose thrive from his [the nightingale's] complaint.

(Mohl jibi IV, p. 281 l. 2396b)

1.34 Qazvin Museum.

- ASMC $1985\left[\mathrm{n}^{\circ}{ }_{12}\right]$, Figure 10.

- Masuya 19

\section{Volume v: Eight Tiles}

Agar dust gardad torā $p \bar{a} d s h \bar{a} /$ If the king has a liking for you.

(Mohl, Jibi v, p. 94, l. 1020a)

1.35 Daussy-Ricqlès, Drouot 22 juin 1992, no. 18 (former Abrami collection).

- Masuya 20

Berahne cho zāyad ze mādar kasi / Naked like one just born to a mother.

H. 1 (Mohl jibi v, p. 98 l. 1118a)

1.36 Manzi collection, Catalogue des faïences anciennes ... composant la collection de feu M. Manzi, Paris, Galerie Manzi, Joyant et Cie, 21 mars 1919, no. 178 (28 cm by side).$^{79}$ The tile is now in Mohtashemi collection: www.amirmohtashemi.com/artworkdetail/ 834584/17919/takht-e-soleyman-tile.

- ASMC 1985 [n $\left.{ }^{\circ} 13\right]$, p. 284.

- Masuya 21

[See Fig. 32]

Konun bar gol-o nār o sib o behi / Now over roses, pomegranates, apples, and quinces.

(Mohl jibi v, p. 33o, l. 1288a)

1.37 Eghvard Church, Cat. 7 .

- Gyuzalyan, ill. 4

- Donabédian and Porter, Figure 43.

[See Fig. 33]

Cho bini rokh-e sib bijäde rang / When you will see the ruby-colored apple-face.

(Mohl, jibi v, p. 330, l. 1289a)

1.38 Eghvard Church, Cat. 43 .

- Gyuzalyan, ill. 5

- Donabédian and Porter, Figure 49

[See Fig. 3]

Shavad āsemān hamcho posht-e palang / The sky will become like the skin of the panther. (Mohl jibi v, p. 33o, l. 1289b) 
1.39 British Museum, 1878,1230.573.2.

www.britishmuseum.org/collection/object/W_1878-1230-573-2

$29.7 \times 30.3 \mathrm{~cm}$

- ASMC 1985 [n $\left.{ }^{\circ} 14\right]$, Figure 11.

- Masuya 22

[See Fig. 6]

Same hemistich.

1.40 Eghvard Church, Cat. 51.

- ASMC 1996, Figure 2.

- Gyuzalyan, ill. 6-6a.

- Donabédian and Porter, Figure 51.

Borumand-o buyā bahāri bovad / When the spring will be filled with riches and scents.

(Mohl jibi v, p. 330, l. 129oa)

1.41 (UCAD 7641) L'art de l'islam, pl. 24.

- ASMC $1985 \mathrm{n}^{\circ} 15$

- Masuya 23

Havā rāst gardad na garm o na sard / The air will become pleasant, neither hot nor cold.

(Mohl, Jibi 5, p. 330, l. 1291a)

1.42 Reza Abbasi Museum, Tehran.

Unpublished

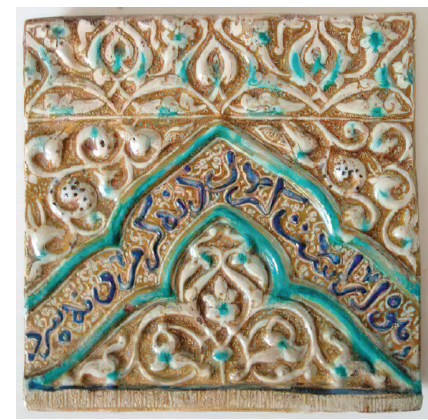

THUMBNAIL 6

Cat. 1.42. Reza Abbasi Museum,

Tehran

(C) PHOTO ANAÏS LEONE

\section{Volume vi: One Tile}

Hami āmad az bustān bu-ye moshk / A scent of musk was coming from the garden.

(Mohl jibi vi, p. 48, l. 33b)

1.43 (UCAD)

https://art.rmngp.fr/fr/library/artworks/carreau-a-l-arc-trilobe_lustre-metallique_moule -technique_decor-sous-glacure_rehauts-de-couleur_decor-sur-glacure_ceramique -siliceuse

- ASMC $1985\left[n^{\circ} 16\right]$, Figure 12.

- Masuya 24

\section{Volume vII: Three Tiles}

Cho az khanjar-e ruz bogrikht shab / When the night escaped from the sword of the day. (Mohl Jibi vis, p. 9, 1.136a)

1.44 (al-Sabah, Kuwait)

- ASMC 1985, Figure 13.

- Masuya 25

Nagashti sepehr-e boland az baram / You did not circle the height of heaven out of my burden.

(Mohl, jibi viI, p. 215, l. 3b)

1.45 Art Curial, Hermès. Boisgirard, 27/05/2011 n¹10.

www.auction.fr/_fr/lot/carreau-a-arche-trilobee-iran-art-ilkhanide-1270-1275-2917806 $30.3 \times 29.5 \mathrm{~cm}$

Unpublished

Resānande-ye ruzi-ye fil-o mur / Daily provider of elephants and ants.

(Variant of Mohl jibi viI, p. 229, 1. 357b) 


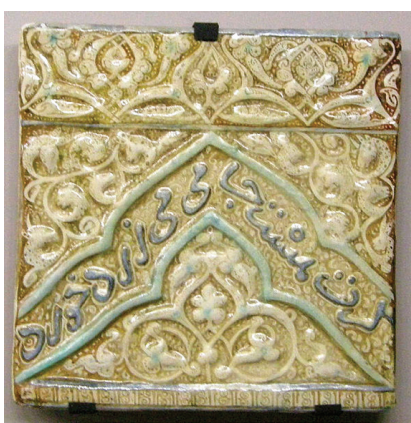

THUMBNAIL 7

Cat. 1.52. Museo d'Arte Orientale, Torino

(c) WIKICOMMONS
1.46 Christie $1986 \mathrm{n}^{\circ} 264$.

- ASMC $1991\left[\mathrm{n}^{\circ} 4\right]$, Figure 16.

- Masuya 31

\section{Unread/Unreadable and Variants: Eight Tiles}

Unread

1.47 Okayama Prefectural Museum of Art.

- Masuya 37

Unread

1.48 Doha, MIA, no. TI.96.2002.

Unpublished?

Magar mehregān āyad bād-e to / Unless autumn will come from your wind. (Variant)

1.49 Rotterdam Museum Ethnology, no. 64820.

- Masuya 34

[See Fig. 34]

Bakhshad har āngah ki khorram shavad / He will bestow delight on every place.

(Variant)

1.5o Eghvard Church, Cat. 11.

Number chehel-se (43) written on back.

- Gyuzalyan, ill. 3

- Donabédian and Porter, Figure 45.

Unread.

1.51 Uto Auktionen, 1976 no.1155.

- Masuya 36

Variant? (... jāmi-ye mey-e zard khworad) / will drink yellow wine from the cup (?) 1.52 Museo d'Arte Orientale, Torino.

https://commons.wikimedia.org/wiki/File:Iran,_mattonella,_xii-xiii_sec.JPG?fbclid=Iw ARuufFQ33CQWhyjSGKcm3suKqKPtvbMMFKbS5jocfhsUoTReVDxSC-vYt-w Unpublished?

Unread, composite.

1.53 Islamic Works of Art from the Collection of Harrison M. Schaek, Toronto, Waddington's Auction House, 2011. tile is 13" (=33 cm) by 13.75". 19 November 2018, lot no. 81 .

www.lot-art.com/auction-lots/Kashan-Calligraphic-Luster-Tile-Persian-13th-14th/81 -kashan_calligraphic-19.11.18-hudvalauctioneers

Unpublished

Unread, composite.

1.54 Private collection.

www.agefotostock.com/age/en/Stock-Images/Rights-Managed/IAM-WHA-o52-0199? fbclid=IwAR131iUBd32XoFAorBPGSbG41b7JocExOt-B8IwYlD2onXhYCriVIZ9RffI

Unpublished 
Fragments (possibly from Frieze $\boldsymbol{I}$ )

1.55 Berlin I. 4/67.35

Masuya sn

1.56 Do abru- (?) / Two eyebrows (?)

(Mohl jibi, v, p. 67, l. 38oa)

MNC sn

Unpublished

1.57

MNC 6924

Unpublished

$1.5^{8}$

MNC sn

Unpublished

1.59-1.6o

Muze-ye melli

- Masuya 39-40

1.61-1.62 Ganjine-ye Melli, Tehran.

- Masuya, unnumbered (F., p. 720).

[See Fig. 19]

1.63 Zulfabad.

- Sedighian, 2011: 1195 and ill. 3.

Frieze II: Three Tiles (2.1-2.3)

[See Fig. 7]

Ke man shärestān-am 'aliyam darast/ I am [like] palace and garden, 'Ali is my gate.

(Slight variant of Mohl jibi I, p. 8, l. 101a)

2.1 Sèvres, MNC 18289, don Stora.

$28.6 \times 21.3 \mathrm{~cm}$

- ASMC 1991, pp. 93-4; 1996, pp. 9-10 and Figure 1.

- Masuya 4 (included in Frieze I)

Be pāliz bolbol benālad hami / In the meadow shall thus the nightingale complain.

(Mohl, jibi Iv, 281, l. 2396a)

2.2 San Francisco

- Masuya 18 (included in Frieze I)

Cat. 1.58. MNC Sèvres

(C) PHOTO YVES PORTER

Hami shād dārad ze Nushin Ravān / Unceasingly joyful thanks to Nushin Ravān.

(Variant of Mohl jibi vol. vi, p. 158, l. 1865a)

2.3 Leipzig, Kunstgewerbe Museum (reproduced in Walter Schultz, Die persischislamische Miniaturmalerei, Leipzig, 1914, I pl. A).

- ASMC 1996, pp. 10-11, Figure 4.

- Masuya 32 (included in Frieze I) 
Frieze III (Four Tiles and Two Fragments, Nos. 3.1.-3.6)

Kherad dast girad be har do sarāy / Wisdom will overspread on both palaces.

(Mohl, Jibi I, p. 4, l. 19b)

3.1 Christies, 7 October 2011, no. 181.

$30.5 \times 29.5 \mathrm{~cm}$

Unpublished?

Ke àmad piyāde gov-e tāj baksh / The crown-bestowing hero came walking.

(Mohl, Jibi II, p.39, l. 55a)

3.2 Sotheby, 25 April 1996.

$29.4 \times 30.5 \mathrm{~cm}$

- ASMC 1996, p. 15, Figure 7.

Bedin din-e khorram bemānam derāz / In this delightful religion I shall dwell for long. (Mohl, Jibi II, p. 98, ligne 1ob)

3.3 Christies, 18 October 1994, no. 297.

$30.3 \times 30.9 \mathrm{~cm}$

- ASMC 1996, p. 14, Figure 6.

[See Fig. 8]

3.4 Victoria and Albert Museum, no. 542-190o

http://collections.vam.ac.uk/item/O280535/tile-unknown/

$19.6 \times 30.3 \times 4 \mathrm{~cm}$

- ASMC 1996, pp. 15-16, Figure 8.

THUMBNAIL 11

Cat. 3.5. MNC Sèvres

3.5 Sèvres, MNC sn

Unpublished

[See Fig. 9]

3.6 Sèvres, MNC sn

Unpublished

\section{Frieze IV (Two Tiles: 4.1 and 4.2)}

... sereshte nabud/be dād o dahesh ... / [he] was not made of / By justice and generosity. (Mohl, Jibi 1, p. 57, end of 1. 532b to beginning of l. 533a)

4.1 Fitzwilliam Museum, Cambridge C.43-1924.

Tiles mixing subsequent hemistiches are very rare.

- Firuza Melville, Zahhak from Cambridge and Bahram Gur from Geneva: Two Unpublished Lustre Tiles with Shahnama Verses, in G. van den Berg and C. Melville, Shahnama Studies II, Leiden, Brill, 2018, p. 320, Figure 12.1.

[See Fig. 10]

[Do abru kamānva] do narges dozham / Two eyebrows like a bow and two cruel narcissus.

(Mohl jibi v, p. 67, l. 38oa)

4.2 Victoria and Albert Museum, no. 544-190o

$29.8 \times 31 \mathrm{~cm}$

- ASMC 1996, pp. 19-20, Figure 12.

- Firuza Melville, "Zahhak from Cambridge," p. 321, Figure 12.2. 
Frieze v (Seven Tiles: 5.1-5.7)

Hamesh sarv-e bālā hamesh moshk muy / All in all a tall cypress with musk-scented hair. (Mohl, Jibi III, p. 154, l. 177b)

5.1 Eskanazi Museum, University of Indiana, Bloomington, accession no. 1961.72 a.

Unpublished?

Khonok ānke delshād dārad be-nush / Happy the one who drinks and feels contented.

(Mohl, jibi IV, p. 281, l. 2392b)

5.2 Christies, 18 October 1994; Kuala Lumpur.

- ASMC 1996, Figure 9.

Kharāmān shode sarv hamcho tazarv / The strutting cypress became like a pheasant.

(Mohl, Jibi v, p. 319, l. 1022b)

5.3 Deniz and Pierre Darier collection, Geneva.

$26.5 \times 28 \times 3.5 \mathrm{~cm}$

- Firuza Melville, "Zahhak," p. 324, Figure 12.3.

[Hamā] n zir-e angosh[tari-ye moshtari] / ... under the ring, [like Jupiter].

(Mohl jibi vi, p. 177, l. 2312b)

5.4 Fragment, Rudolf Naumann collection.

- ASMC 1996, pp. 16-18, Figure 10.

Agar māh dārad do zolf-e siyāh / If the moon has two black curls.

(Mohl, jibi viI, p. 101, l. 2373b)

5.5 Eskanazi Museum, University of Indiana, Bloomington, accession no. 1961.72b.

Unpublished?

Do rokhsāre tābān be kerdār-e māh / Two shining cheeks resembling the Moon.

Variant

5.6 Fogg Museum of Art 1958-47.

https://upload.wikimedia.org/wikipedia/commons/a/a7/Frieze_Tile_with_Inscription

$\% 2 \mathrm{C} \_B i r d s \% 2 \mathrm{C}$ and_Flowers\%2C_c.1270s\%2C_Ilkhanid_dynasty\%2C_probably_Takht

-i_Sylayman\%2C_Iran_-_Sackler_Museum_-_DSCo2487.JPG

- ASMC 1996, Figure 11.

- Firuza Melville, "Zahhak," p. 325, Figure 12.4.

[See Fig. 11]

Golafshān konad chun sarāyad sokhan / He who sings these words will be scattering roses.

Variant

5.7 Reza Abbasi Museum, Tehran.

Unpublished

Frieze vi (Four Tiles: 6.1-6.4)

[bar-än sefat-e] siminash meshkin kamand / His/her silvery appearance and musk-like hair-locks.

(Mohl, jibi I, p. 123, l. 386a)

6.1 Private collection. 


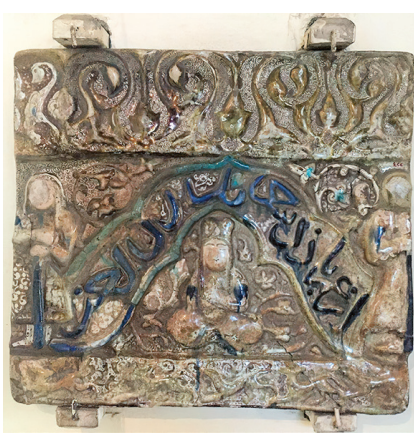

THUMBNAIL 13

Cat. 8.1. Gayer Anderson Museum, Cairo

(C) PHOTO ANAÏS LEONE
www.meisterdrucke.uk/fine-art-prints/Persian-School/414914/Moulded-frieze-tile -made-for-the-palace-of-the-Mongol-Sultan-Abaqa-Khan,-c.1270-75-(ceramic,-frit, -underglaze-and-lustre-overglaze).html

Unpublished?

[See Fig. 12]

[Sekandar biyāmad] be-shahr andarun / Alexander came inside the city.

(Variant, composite?)

6.2 Brooklyn Museum, no 42.212.21.

$24 \times 25.8 \mathrm{~cm}$

- ASMC 1996, p. 22, Figure 14.

rāgh ... be kerdār-e sarv-e boland / The meadow ... like a tall cypress.

(Variant, composite?)

6.3 London, 1990.

ASMC 1996, pp. 24-5, Figure 15.

Composite

6.4 London sale, 1990.

- ASMC 1996, p. 25, Figure 16.

\section{Frieze VII (One Tile)}

[be digar ze doshm-] an hami jost rāh / With the other, trying to escape from the enemy. (Fragment, Mohl, jibi III, p. 141, 1. 116b)

7.1 (Uto Auktionen) Oriental Art Auctions (orientalartauctions.com), Islamic \& Asian Art, 29 March 2020, no. 44.

www.lot-art.com/auction-lots/TWO-KASHAN-TILE-SHARDS/44-two_kashan-29.3.20 -orientartauc

$20 \times 22.5 \mathrm{~cm}$

- ASMC 1996, p. 21, Figure 13.

- Masuya 33 (included in Frieze I)

\section{Frieze VIII, with Anvari's Qasida No. 83 (Seven Tiles: 8.1-8.7, Plus Fragments)}

8.1 [afz] ār / 'omre-hā dar ['emārat-at ...] end of verse 14/beginning of 15 . Gayer Anderson Museum, Cairo.

[See Fig. 16]

8.2 ... khanjar ... (bait 29?)

Reza Abbasi Museum, former “Collection T.L. Jacks," H. $41 \mathrm{~cm}$.

A.U. Pope, A Survey of Persian Art (reprint Tokyo, 1971), vol. X, p. 726, Figure B.

[See Fig. 15]

8.3 [ze Ir] ān hamvār / ān qadr-e qodrat-e qazā peymān va ān (end of bait 33/beginning of bait 35).

Chicago Art Institute, no. 1939.368

www.artic.edu/artworks/30631/tile-fragment-with-figure-in-a-niche

$41.5 \times 28.9 \times 4.2 \mathrm{~cm}$ 
8.4 [Hemmatash rā cho] bahr-e estezhār ... end of bait 41.

Sotheby's, Arts of the Islamic World, London, 25 April 2018, Lot 114. $44 \times 49 \mathrm{~cm}$. Provenance: Private collection, Lyon, France, early twentieth century. Purchased at M.A.M Indjoudjian, 26 rue Lafayette, Paris. www.sothebys.com/en/auctions/ecatalogue/ 2018/arts-of-the-islamic-world-l18220/lot.114.html

8.5 Composite, unread.

Khalili collection, no. POT1532, $41 \times 47.5 \mathrm{~cm}$; www.khalilicollections.org/collections/ islamic-art/khalili-collection-islamic-art-cornice-tile-pot1532/

"Small" frieze with Anvari's qasida (?)

[See Fig. 23]

8.6 Composite.

Reza Abbasi Museum, Tehran

H. c. $31 \mathrm{~cm}$

8.7 Composite.

Art Curial, Paris 2014, Former collection Xavier Guérand-Hermès, $31.5 \times 40 \mathrm{~cm}$; www .artcurial.com/fr/lot-carreau-lustre-au-personnage-tronant-takht-i-sulayman-art-il -khanide-vers-1270-ad-2497-131

Fragments

[Figure 17]

- Brooklyn Museum no. 86.227.69; $14 \times 10.2 \mathrm{~cm}$. www.brooklynmuseum.org/opencollection/objects/124888

- Vente Sabourin, Châtellerault 10/11/o2, lot no. c; $29 \times 11 \mathrm{~cm}$ (formerly Chavaillon collection).

\section{About the Author}

Yves Porter is a specialist on arts and techniques in the Iranian world and Islamized India. He obtained a PhD in Iranian studies (1988). Since 1993, he teaches Islamic art at Aix Marseille and is a member of the LA3M/CnRs. Since October 2018, he joined the Institut Universitaire de France.

\section{Bibliography}

Abu Dulaf Yanbu'i (1955). al-Resāla al-tāniya. Edited and translated by Vladimir Minorsky as Abu-Dulaf Mis'ar Ibn Muhalhil's Travels in Iran. Cairo: Cairo University Press.

Abu al-Qāsim Kāshāni (1966). 'Arāis al-jawāhir wa-nafāi is al-ațāỉb. Edited by I. Afshār. Tehran: AAM.

Alizadeh, A. (1990). ČAŠMA(-YE) 'ALİ. In: Encyclopaedia Iranica, https://iranicaonline.org/ articles/casma-ye-ali-lit.

Allan, J. (2001). Gold, ii. In Islamic Persia. In: Encyclopaedia Iranica, www.iranicaonline.org/ articles/gold\#Islamic.

Allegranzi, V. (2019). Aux sources de la poésie ghaznavide. Les inscriptions persanes de Ghazni. Paris: PSN.

Amanat, A. (1998).Ectemād-al-Salțana. In:Encyclopaedia Iranica, https://iranicaonline.org/articles/ etemad-al-saltana. 
Amirhajloo, S., Emami, M., Agha-Aligol, D., and Riahiyan Gohorti, R. (2020). Preliminary Studies on Polychrome Luster Tiles Excavated from Qal'eh Dokhtar in Kerman by X-ray, SEMEDX and Micro-PIXE Spectroscopy: Insight into a New Production Center of Lusterware in Southeast of Iran. Journal of Archaeological Science: Reports 33, https://doi.org/10.1016/j .jasrep.2020.102456.

Anvāri (n.d.). Divān, qasida no. 83, https://ganjoor.net/anvari/divan-anvari/ghaside-anvari/sh83/.

Aubin, J. (1971). Réseau pastoral et réseau caravanier: les grand'routes du Khorassan à l'époque mongole. Le monde iranien et l'Islam 1, pp. 105-30.

Bariand, P. (1972). Origine de l'or de Zarehshuran (Iran occidental). Bulletin de la Société Française de Minéralogie et de Cristallographie 95, pp. 625-9.

Blair, S. (1986). The Mongol Capital of Sultaniyya, "the Imperial." Iran 24, pp. 139-52.

Blair, S. (1993). The Ilkhanid Palace. Ars Orientalis 23, pp. 239-48.

Blair, S. (2014). Text and Image in Medieval Persian Art. Edinburgh: Edinburgh University Press.

Bosworth, E.C. (2001). The History of the Seljuq Turks: The Saljuq-Name of Zakir al-Din Nishapuri. London: Routledge.

ChamedanMag (2018). Kārgāh-e sofāl-e Alamut rāh-andāzi shod. 5 Aban 1397/27 October 2018, www.chamedanmag.com/news/187839/.

Chubak, H. (2009). Alamut Castle (Eagle's Nest): Hassan Sabbah Stronghold. The International Journal of Humanities 16/2, pp. 1-28.

Dashdondog, B. (2011). The Mongols and the Armenians. Leiden: Brill.

Der Nersessian, S., and Mekhitarian, A. (1986). Armenian Miniatures from Isfahan. Brussels: Editeurs d'Art/Armenian Catholicosate of Cilicia.

Donabédian, P., and Porter, Y. (2017). La chapelle de l'alliance (Arménie, début XIV e siècle). Hortus artium medievalium:Journal of the International Research Center for Late Antiquity and Middle Ages 23/2, pp. 837-55.

E'temād al-Saltana (1976). Mațla' al-šams (3 vols, Tehran, 1301-3/1884-6; reprint in 1 vol.). Tehran: Sāzmān-e Shāhanshāhi-ye Khedmat-e Ejtemāii.

Farrokhi Sistani (n.d.). Divān, https://fa.wikisource.org/wiki/_وخى_سيستانى(قصايد)/خداوندما_شاه كثورستان.

Fars News Agency (2012). Iran's Biggest Gold Mine Reserves Stand at 4mln Tons. March 14, https://web.archive.org/web/20120314145759/http://english.farsnews.com/newstext.php?nn $=8120000009$.

Firdausi (1966). Shah-nama (8 vols). Edited by Jules Mohl. (Reprint) Tehran: Ketāb-hā-ye Jibi.

Focillon, H. (1934). Vie des formes. Paris: E. Leroux.

Fouchécour, C.-H. de (1969). La description de la Nature dans la poésie lyrique persane du XI siècle. Paris: Klincksieck.

Froom, A. (2008). Persian Ceramics from the Collection of the Asian Art Museum. San Francisco: Asian Art Museum.

Ghuchāni, 'A. (1992). Persian Poetry on the Tiles of Takht-i Sulaymân. Tehran: Iran University Press (in Persian).

Graves, M. (2014). Kashan vii: Kashan Ware. In: Encyclopaedia Iranica, www.iranicaonline.org/ articles/kashan-vii-kashan-ware.

Gyuzalyan, L.T. (1984). Iranskie Izratsi na Barabane Khrama v Egvarde. Istoriko filologicheski Jurnal 1, pp. 153-74.

Haneda, M. (1989). Gazaniyya in Tabriz. Proceedings of the International Conference on Urbanism in Islam (ICUIT), vol. 2. Tokyo: The Middle Eastern Culture Center, pp. 283-99.

Hatef Naiemi, A. (2020). The Ilkhanid City of Sultaniyya: Some Remarks on the Citadel and the Outer City. Iran, https://doi.org/10.1080/05786967.2020.1744469.

Hoffmann, B., Korn, L., Lorain, T., Elbers, J., and Moeini, M. (forthcoming). Prestigious Building and Urban Development in Ilkhanid Iran: The Case of the Rab'-i Rashīdī in Tabriz. Resilience and Vulnerability in a Long-Term Perspective. In: R. Bernbeck et al., eds., Coming to Terms with 
the Future: Concepts of Resilience for the Study of Premodern Societies. Papers of the Conference of the DFG-SPP "Iranian Highlands," 5-6 December 2020.

Hourcade, B. (1977). Les nomades du Lâr face à l'expansion de Téhéran. Revue Géographique de l'Est 17/1-2, pp. 37-51.

Huff, D. (2006). The Ilkhanid Palace at Takht-i Sulayman: Excavation Results. In: L. Komaroff, ed., Beyond the Legacy of Gengis Khan, Leiden: Brill, pp. 94-110.

Irib News Agency (2020). Khabar gozāri-ye sedā vā simā, Barresi-ye yeksad nemune-ye kāshi-ye zarrin fām-e soltāniye, 12 Dey 1398/2 January 2020, https://zanjan.mcth.ir/news/ID/488/.

K'alant'aryan, A.A. (2009). Armenia in the Cultural Context of East and West: Ceramics and Glass, 4th-14th Centuries. Erevan: Gitutyun.

Komaroff, L., ed. (2006). Beyond the Legacy of Gengis Khan. Leiden: Brill.

Komaroff, L., and Carboni, S., eds. (2002). The Legacy of Gengis Khan: Courtly Art and Culture in Western Asia, 1256-1353. New York: Metropolitan Museum of Art.

Korkhmazian, E. (1984). Armenian Miniatures of the 13th and 14th Centuries from the Matenadaran Collection, Yerevan. Leningrad: Aurora.

Leone, A. (forthcoming). New Data on the Luster Tiles of 'Abd al-Samad's Shrine in Natanz (Iran, 707/1307-08). Muqarnas 38 .

Masuya, T. (1997). The Ilkhanid Phase of Takht-i Sulaiman, PhD Dissertation, Graduate School of Arts and Science, Institute of Fine Arts, New York University.

Masuya, T. (2000). Persian Tiles on European Walls: Collecting Ilkhanid Tiles in NineteenthCentury Europe. Ars Orientalis 30, pp. 39-54.

Masuya, T. (2002). Ilkhanid Courtly Life. In: L. Komaroff and S. Carboni, eds., The Legacy of Gengis Khan: Courtly Art and Culture in Western Asia, 1256-1353, New York: Metropolitan Museum of Art, pp. 74-103.

Mélikian-Chirvani, A.-S. (1984). Le Shah-nama, la gnose soufie et le pouvoir mongol. Journal Asiatique t. CCLXXII/3-4, pp. 249-337.

Mélikian-Chirvani, A.-S. (1988). Le Livre des Rois, miroir du destin. Studia Iranica 17/1, pp. 7-46.

Mélikian-Chirvani, A.-S. (1991). Le Livre des Rois, miroir du Destin II. Takht-e Soleymân et la symbolique du Shah-nama. Studia Iranica 20, pp. 33-148.

Mélikian-Chirvani, A.-S. (1996). Les frises du Shāh Nāme dans l'architecture iranienne sous les Ilkhān. Cahier Studia Iranica 18. Paris: AAEI.

Melville, C. (2002). The Mongols in Iran. In: L. Komaroff and S. Carboni, eds., The Legacy of Gengis Khan: Courtly Art and Culture in Western Asia, 1256-1353, New York: Metropolitan Museum of Art, pp. 36-61.

Melville, F. (2018). Zahhak from Cambridge and Bahram Gur from Geneva: Two Unpublished Lustre Tiles with Shahnama Verses. In: G. van den Berg and C. Melville, eds., Shahnama Studies III: The Reception of the Shahnama, Leiden: Brill, pp. 317-46.

Momenzadeh, M., Nezafati, N., Sarraf, M.R., and Shabani, K. (2016). Ancient Gold-Mercury Mining in the Takht-e Soleyman Area, Northwest Iran. Metalla 22/2, pp. 147-68.

Mustawfi, H. (1919). The Geographical Part of the Nuzhat al-Qulub. Translated by G. Le Strange. Leiden/London: Brill/Luzac.

Naumann, R. (1977). Die Ruinen von Tacht-e Suleiman und Umgebung. Berlin: Reimer Verlag.

Petrosyan, H.L. (1988). Garni, gth-14th Centuries [qunuhu IX-XIV nuntrnıu]. Erevan: Akademia Nauk.

Pope, A.U. (1971). A Survey of Persian Art, vol. x, Plates, Pottery and Faience (1938-39). (Reprint) Tokyo: Meiji Shobo.

Porter, Y. (2018). Les potiers de Kâshân (fin XII e début XIVe siècle): splendeurs et mystères d'une production persane. In: S. Burri and M. Ouerfelli, eds., Artisanat et métiers en Méditerranée médiévale et moderne, Aix-en-Provence: Presses Universitaires de Provence, pp. 425-67.

Porter, Y. (forthcoming). Distorsions culturelles dans l'étude de l'art iranien. Colloque Iran: entre héritages pluriséculaires et réalités contemporaines, MMSH Aix-en-Provence, 27-28 mars 2018. 
Puerta Vilchez, J.-M. (2010). Leer la Alhambra. Granada: Patronato de la Alhambra.

Qazi Ahmad Qomi (1959). Calligraphers and Painters. Translated by V. Minorsky. Washington: Freer Gallery.

Réau, L. (1951). L'influence de la forme sur l'iconographie. Formes de l'art, formes de l'esprit (Journal de Psychologie. Numéro spécial), pp. 85-105.

Rougeulle, A., Creissen, Th., and Bernard, V. (2012). The Great Mosque of Qalhat Rediscovered: Main Results of the 2008-2010 Excavations at Qalhat, Oman. Proceedings of the Seminar for Arabian Studies 42, pp. 341-56.

Roxburgh, D.J. (2005). The Persian Album, 1400-1600: From Dispersal to Collection. New Haven: Yale University Press.

Sedighian, H. (2011). Barresi-ye kashiha-ye zarrin-fam mahute-ye zulfabad farahan ostan-e markazi. Majmu'e-ye maqalat-e Bastan shenasi-ye Iran dar dowran-e eslami, pp. 1169-1200.

Siri, M.S., and Amirhajloo, S. (2020). Review of Seven Pieces of Luster Tiles in the National Museum of Iran: New Archaeological Finds from Lar Plain in Tehran. Majalle-ye Muze-ye Melli-ye Iran 1/1, pp. 147-6o.

Smith, J.M. (1999). Mongol Nomadism and Middle Eastern Geography: Qishlaqs and Tümens. In: R. Amitai-Preiss and D.O. Morgan, eds., The Mongol Empire and Its Legacy, Leiden: Brill, pp. $39-56$.

Sotheby's (2018). Arts of the Islamic World. London, 25 April.

Soucek, P.P. (1982). 'Abdallāh Șayrafî. In: Encyclopaedia Iranica, https://iranicaonline.org/articles/ abdallah-sayrafi-calligrapher.

Watson, O. (1977).Persian Lustre Tiles of the Thirteenth and Fourteenth Centuries, PhD Dissertation, soAs, University of London.

Watson, O. (1985). Persian Lustre Ware. London: Faber \& Faber.

Wilber, D.N. (1955). The Architecture of Islamic Iran: The Il Khanid Period. Princeton: Princeton University Press.

Wing, P. (2014). "Rich in Goods and Abounding in Wealth": The Ilkhanid and Post-Ilkhanid Ruling Elite and the Politics of Commercial Life at Tabriz, 1250-140o. In: J. Pfeiffer, ed., Politics, Patronage and the Transmission of Knowledge in 13th-15th Century Tabriz, Leiden: Brill, pp. 301-20.

Zhamkochyan, A. (1981). The Faience of Medieval Armenia in the 9th-14th Centuries

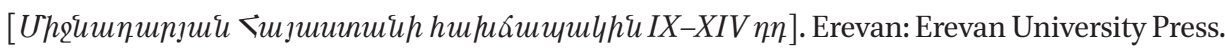

Zhamkotchyan, A., and K'alant'aryan, A. (1971). Faience Tiles from the Church of Eghvard

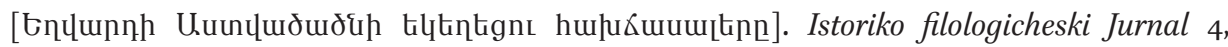
pp. $277-81$.

\section{Notes}

1 This paper is part of the Kashan Luster Project (2018-23) undertaken through the Institut Universitaire de France (IUF). The author addresses his warmest thanks to all the curators and scholars who helped him during this research, especially Qamar Adamjee (San Francisco), Persis Berlekamp (Chicago), Nicoletta Fazio (Doha), Mary McWilson (Cambridge, MA), Leslee Michelsen (Honolulu), Mohammad Sepehr Siri (Tehran), Lorenz Korn (Bamberg), Patrick Donabédian and Anaïs Leone (Aix-en-Provence), and Richard Castinel. Thanks are extended to both the anonymous reviewers for their valuable advice.

2 Two are kept in the Museum für Islamische Kunst, Berlin:

'Nr. I. 4/67.35.1; H.: 10; W. 9.7; th. 3.1 cm. Unpublished? See Cat. 1.55 (numbers in bold refer to the annexed Catalogue of tiles).

Nr. I. 4/67.35.2; the height dimension given by the museum online data $(36.3 \mathrm{~cm})$ cannot be correct; width: $18.4 \mathrm{~cm}$; thickness: $3.6 \mathrm{~cm}$ (Cat. 1.13).'

Two fragments belong to the Ganjine-ye Markazi, Tehran (Cat. 1.61-1.62; Masuya, 1997: Pl. 201a-b). Two other fragments (Cat. 1.59-1.6o), in the Muze-ye Melli, Tehran (both under no. 3302), are allegedly "nonexcavated" (Masuya, 1997: Pl. 202n-o). 
3 Hundreds of fragments of luster tiles have recently been unearthed in several Iranian locations; in some cases, the fragments are too small, or insufficiently studied, such as in material excavated from Sultaniya and Alamut. For Sultaniya, see Irib News Agency (2020). For Alamut, see Chubak (2009); see also ChamedanMag (2018). At least one fragment from Zulfabad undoubtedly belongs to the trilobed series (Cat. 1.63). See Sedighian (2011: 1195, ill. 13). For the Armenian church at Eghvard, see Gyuzalyan (1984); see also Donabédian and Porter (2017).

4 Watson (1977: 103, 105-6) listed eleven items. In his three publications devoted to the subject (Mélikian-Chirvani, 1984, 1991, 1996), Mélikian-Chirvani describes a total of forty tiles, belonging to the seven series exposed hereafter. Masuya (1997: 484-504, 716-20) proposed a list of forty tiles and some fragments belonging to Friezes I and II.

5 British Museum, no. 1878,1230.573.1 (Cat. 1.28) and 1878,1230.573.2 (Cat. 1.39).

6 Asian Art Museum, San Francisco, no. B6oP2145 (Cat. 2.2) and B6oP2146 (Cat. 1.32); reproduced in Froom (2008: 86-7).

$7 \quad$ Graves (2014): "The hypothesis that Kashan was the only site of luster production within the medieval Iranian lands is still under discussion." More recently, see Amirhajloo et al. (2020).

8 Masuya delivered an in-depth study on the particulars of Takht-i Sulaiman's eight-pointed luster star tiles, concerning dates (Masuya, 1997: 368-77), Shah-nama quotations (Masuya, 1997: 400-5), and other verses (Masuya, 1997: 377-400). She concluded they formed a distinct production among other luster star tiles. However, the location of their manufacture was not discussed in these pages.

The exemplar instance of this type of bias in historical sources is provided by the History of the Twelve Caesars, as pictured by Suetonius and later notoriously relayed by E. Gibbon in his monumental History of the Decline and Fall of the Roman Empire (published 1776-88). Modern history has considerably reassessed the figures of these "decadent" Roman emperors, while the critical reading of Ilkhanid sources has not always reached comparable levels.

10 Apart from the trilobed series, Mélikian-Chirvani (1996: 35-63) has identified at least ten different friezes of luster "linear" tiles quoting the Shah-nama, in addition to two others made of turquoise glazed molded tiles. On the so-called waq-waq motif, see Porter (forthcoming).

12 Alafia, in Spanish, designates a motif frequently seen on Hispanic ceramics, formed or inspired by the Arabic letters lām-'ayn-alif, in abbreviation of al-'áfiya, "[good] health."

13 Among the forty items listed by Masuya (1997: 716-20, Chart XVIII: Shahnama quotations on 6-1-G Tiles), some belong to Frieze II.

14 Besides the pair of tiles from Eghvard Church (Cat. 1.29 and 1.40), other almost identical tiles are Cat. 1.2 (present location unknown) and $\mathbf{1 . 3 3}$ (Reza Abbasi Museum).

15 Some scholars believe that the palace at Tiknuni (next to Dvin) might have been ordered by Hulagu (K'alant'aryan, 2009: 169); it could have been occupied later by his successors.

16 Mélikian-Chirvani (1996: 10) considers the tile from Leipzig as forming a different frieze (his Frieze II, see his Figure 4). His Frieze III (1996: Figure 5), in my opinion, closely resembles Frieze I.

17 On this question, see Réau (1951); see also Focillon (1934: especially 1-7).

18 See, for instance, a Quranic frieze, probably dated 738/1337, in the Victoria and Albert Museum (nos. 1490A and 1490B-1876).

19 Fitzwilliam Museum, Cambridge, no. C.43-1924; Victoria and Albert Museum, no. 544-190o (Myers Collection). Both tiles published by Melville (2018: Figs 12.2 and 12.3).

20 Brooklyn Museum no. $42.212 .21: 24 \times 25.8 \mathrm{~cm}$.

21 Museum für Islamische Kunst, Berlin, no. I.13/67a and b; H. c. $23 \mathrm{~cm}$, W. c. $24.5 \mathrm{~cm}$. On the fragment of a Quranic tile of the same model found at Qalhat (Oman), see Rougeulle et al. (2012: 341-56).

22 Mélikian-Chirvani (1996: Figures 20-23).

23 Musée National de la Céramique, Sèvres, no. 18291.

24 Asian Art Museum, San Francisco, no. B6oP2035.

25 Shangri La, DDF 48.356, from Sotheby's Parke Bernet, o8/12/1967.

26 Chicago Art Institute, no. 1939.368; $41.5 \times 28.9 \times 4.2 \mathrm{~cm}$.

27 Thanks are due to Will Kwiatkovski for leading me to this poem. Anvāri (n.d.), Dar ta'rif-e 'emarat va madh-e Saheb Nasir al-Din Taher. Nasir al-Din Taher b. Fakhr al-Mulk b. Nizam al-Mulk Tusi was Sultan Sanjar's vizier; see Bosworth (2001: 96).

28 Khalili collection, no. POT1532, $41 \times 47.5 \mathrm{~cm}$.

29 Sotheby's (2018: Lot 114). "A rare Ilkhanid moulded lustre pottery tile, Persia, probably Takht-i Suleyman, 13th-14th century; 44 by $49 \mathrm{~cm}$. Provenance: Private collection, Lyon, France, early 2oth century. Purchased at M.A.M Indjoudjian, 26 rue Lafayette, Paris." The sale's catalogue notes that the text is "Undecipherable."

$30 \quad$ Pope (1971: vol. X, 726, Figure B); former "Collection T.L. Jacks," H. 41 cm. See Cat. 8.2.

31 Art Curial, Former collection Xavier Guérand-Hermès, $31.5 \times 40 \mathrm{~cm}$. Cat. 8.7. 
Fragments with figures: Museum für Islamische Kunst, Berlin, no. I.485 and 486, from Sarre, 1907; I.953; I. 2221, from Filippo, Paris, 1912. Brooklyn Museum no. 86.227.69; $14 \times 10.2 \mathrm{~cm}$. Two other fragments, framed together; see Cat. 8.9, Vente Sabourin, Châtellerault 10/11/o2, lot no. c; $29 \times 11 \mathrm{~cm}$ (formerly Chavaillon collection).

Cat. 1.32. Asian Museum, no. B6oP2145. Froom (2008: 86, no. 33) writes that these tiles "are not contiguous." All quotes from the Shah-nama follow Jules Mohl's "jibi" (pocket) edition, Tehran, 1345/1966; translations are my own.

Cat. 2.2. Asian Museum, no. B6oP2146. The following hemistich, on a tile with a "lām-alif" lower band, is kept in the Qazvin Museum; see Cat. 1.34.

Most of Avery Brundage's ceramics were bought in the 1950s and 196os (Froom, 2008: 8).

The surface of the shard $\left(\mathrm{c} .60 \mathrm{~cm}^{2}\right)$ represents 6.67 percent of the surface of an average tile; the frag-

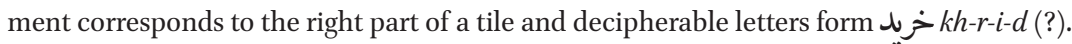

Ferdinand Méchin traveled to Iran in the 186os; on his return, he published Lettres d'un voyageur en Perse, Bourges, 1867. A sale of his collections took place in 1868, in Paris (Catalogue des objets de la Perse ... composant la collection de M. Méchin, $\mathrm{M}^{\text {es }}$ C. Pillet et C. Mannheim, Hôtel Drouot, Paris, 23-25 janvier 1868). Lot no. 207 of this sale comprises "Quantité de fragments de plaques de revêtement, de plats, de bols, etc., en faïence blanche et bleue à décors à reflets métalliques et autres, provenant des fouilles faites à Rheï et à Ferabad." The V\&A Museum has several items sold by F. Méchin in 1868; see the museum online collection: "In the same transaction, Méchin sold the Museum 12 fragments of lustre and mina'i ceramic ware, reportedly excavated by him at Rayy." http://collections .vam.ac.uk/item/O280557/tile-unknown/. None of the Sèvres fragments from Méchin's excavations can be clearly identified as belonging to the "trilobed" series.

According to Rashid al-Din, quoted by Masuya (2002: 80-1).

However, Mustawfi (1919: 79) writes that Rashid al-Din "constructed many high and magnificent palaces" in this location.

On Tabriz, see also Wing (2014: 301-20).

See Hoffmann et al. (forthcoming).

Dashdondog (2011: 155) also mentions a castle on Shahi Island.

According to Blair (1986: 146), "Hafiz-i Abru gives the best description of the enormous palace which Oljeytu built at Sultaniyya. It had a square court paved with marble measuring 100 by $100[\mathrm{gaz}]$. Around the court were a huge iwan like the one in Khusraw's palace at Ctesiphon and twelve smaller units (saraycha), each with a window overlooking the main court."

Matenadaran Library, Ms. 7740; see Korkhmazian (1984: no. 163).

"In this town there is a great palace, in the court of which a spring gushes forth into a large tank, that is like a small lake for size, and no boatman has been able to plumb its depth. This palace [Takht-i Sulaiman] was first (re-)built during the reign of Abaqa (1265-1281)."

See, notably, Mélikian-Chirvani (1991).

This recent publication follows research published in the 196os and early 1970s by Bariand (1972). In this paper, Bariand (1972: 629) already proposed to link the golden objects from the Ziwiye Treasure (seventh century BСE), found near Saqqez (c. $75 \mathrm{~km}$ west of Takab), but also the gilded tiles from Takht-e Sulaiman, with the gold-mining of this area.

Fars News Agency (2012).

Orbelian (1910: 415), quoted by Dashdondog (2011: 77).

We know that Gaikhatu spent several summers between 1292 and 1294 in this yaylaq; see Smith (1999: 42-3).

Taj Ali Shah was a vizier of Abu Sa'id; he first shared the vizierate with his rival Rashid al-Din (12471318), being notably in charge with the government of Anatolia.

K'alant'aryan (2009: 169) suggests the site of Tiknuni (approx. $5 \mathrm{~km}$ north of Dvin) as a possible location for this palace. However, luster tiles were also found at other locations, such as Garni, where Petrosyan (1988: 80-2, Pl. XLVI-XLVII) numbered up to forty fragments.

On the Khorasan route, see Aubin (1971: 105-30).

See Siri and Amirhajloo (2020).

On E'temād al-Saltana, see Amanat (1998).

Tiles from Frieze I with more than one hemistich are exceedingly rare. An exception is our Cat. 1.11: [Ze sar tā] pāyash be-kerdār-e ‘ājj / be-rokh [behesht va bebālā cho sāj] / From head to toe resembling ivory / the face like heaven and the loftiness of the teak-tree (Mohl jibi I, p. 123, l. 385a-b). Victoria and Albert Museum, no. 1696-1892; see Mélikian-Chirvani (1984: [ ${ }^{\circ}{ }_{3}$ ]; 1991: [nº], Figure 23).

For Natanz, see Leone (forthcoming). Concerning Takht-i Sulaiman's dado stars, Ghuchāni (1992) has published the Persian texts of dozens of these (or fragments) in his book.

Arthur M. Sackler Gallery (Washington, DC), S.1986.10o; H × W: $59.3 \times 40.1 \mathrm{~cm}$.

Tiled dados can also be seen on some paintings from Armenian manuscripts; see Library of Armenian Cathedral of All Saviour, New Julfa, MS 47, Gospel dated 1330, fol. 1v, The Annunciation, 
signed by Kirakos of Tabriz (T’avrizetsi); reproduced in Der Nersessian and Mekhitarian (1986: 114, Figure 51, 196).

6o Museum für Islamische Kunst, Berlin, Ident. Nr. I. 6/71 c, for instance.

61 Arthur M. Sackler Gallery (Washington, DC), S.1986.102; H × W: $59.4 \times 40.2 \mathrm{~cm}$.

62 Victoria and Albert Museum, no. 543-190o.

63 The painting, from a Jalayirid Shah-nama (Baghdad or Tabriz c. 1370), appears on a composite album page, TSMK, H. 2153, fol. 55 r.

64 The first word of the numeral is incomplete (bist: 20 or shast: 60 ?).

65 This inscription is complex and overloaded.

66 Not reproduced by Gyuzalyan (1984).

67 The inscription on the back of this tile is overloaded: the first line has a first word (chehel? 40), followed by panjâh [the figure of unit is unreadable] (50?); the second line shows chehel haft (47), and the third lâ [ $]$ ("no"?).

68 Asian Museum B6oP2146 and B6oP2035. Thanks to Qamar Adamjee for allowing close observation of these tiles. For another example of a tile fragment with traces on its back, see Victoria and Albert Museum, no. 550-190o, Cat. 1.26.

69 On Frieze I, forty-six tiles display quotes easily found in the edited text: sixteen tiles correspond to vol. 1, four to vol. 2, three to vol. 3, eleven to vol. 4, eight to vol. 5, one to vol. 6, and three to vol. 7. To these, eight other tiles with unread or variant inscriptions can be added.

70 See Cat. 1.13 (Sindokht, Zāl, in reconstructed text); Cat. 1.25 (Faridun, Hushang); Cat. 2.1 ('Ali); Cat. 2.3 (Nushin Ravān); Cat. 6.2 (Sekandar, in composite tile).

71 On the role of nature in the tashbīb, see Fouchécour (1969:5).

72 As suggested by an anonymous reviewer, a parallel could also be drawn with the later albums (moraqqa) of paintings and calligraphies. See Roxburgh (2005).

73 Konun khword bâyad mey-e khosh gavâr / Gol az nâle-ye u bebâlad hami.

74 The Kerülen (or Kherlen) springs in Mongolia and is an affluent of Lake Hulun, hence of the Amur.

75 Farrokhi Sistani (n.d.). This poem was already quoted by Mélikian-Chirvani (1988: 19-20).

76 No dated luster tiles are known between 1339 and 1455; moreover, only six dated items are recorded for the whole of the fifteenth century.

77 As already mentioned in note 3 , hundreds of fragments have recently been unearthed but are awaiting proper publication.

78 Masuya (1997: 404-5, 492-4) has already considerably advanced this subject.

79 The tile is reproduced (under no. 178) facing p. 42. The notice in the catalogue (p. 32) mistakenly mentions a signature by Yusuf b. 'Ali, of the Abu Taher family; it also refers to the Exposition des Arts Musulmans, $\mathrm{N}^{\circ} 429$ (G. Migeon, M. Van Berchem, and C. Huart, Paris, 19०3) in which the same mistake is repeated. 